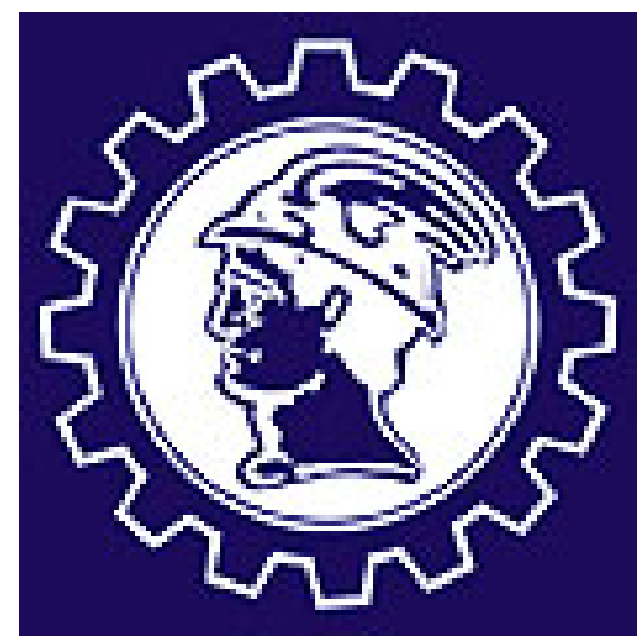

UNIVERSIDADE DE SÃO PAULO

FACULDADE DE ECONOMIA, ADMINISTRAÇÃO E CONTABILIDADE DEPARTAMENTO DE ADMINISTRAÇÃO

\title{
Estrutura Organizacional e Gestão do Conhecimento
}

\section{EDOARDO PERROTTI}

Orientador: Prof. Dr. Eduardo Pinheiro Gondin de Vasconcellos 


\section{EDOARDO PERROTTI}

Orientador: Prof. Dr. Eduardo Pinheiro Gondin de Vasconcellos

\section{Estrutura Organizacional e Gestão do Conhecimento}

Dissertação apresentada ao

Departamento de Administração da Escola de Administração, Economia e Contabilidade da Universidade de São Paulo, como exigência parcial para obtenção do Título de Mestre em Administração.

São Paulo

2004 
Aos meus amados filhos, minhas fontes de energia, Stefano e Bernardo.

À Lelê, minha querida, que sempre esteve ao meu lado com sabedoria, simpatia e amor.

À Mamãe, amor e apoio constantes 


\section{AGRADECIMENTOS}

"Daquelas pessoas de quem menos se espera, é delas que não virá nada mesmo"

Barão de Itararé

Esta dissertação representa os resultados acumulados de um processo de 2 anos e meio de prazerosos mergulhos bibliográficos e contatos com seres humanos interessantíssimos. Àqueles que mais me ajudaram nesta caminhada deixo registrada minha gratidão.

Ao Prof. Dr. Eduardo Vasconcellos pelas sábias orientações que desembaçavam a visão e clareavam o caminho em cada encontro.

À Banca Examinadora do exame de qualificação, Prof. Dr. Isak Kruglianskas e Prof. Dr. José Cláudio Cyrineu Terra, pelas inestimáveis contribuições ao desenvolvimento deste trabalho.

Aos Srs Júlio Fenner, Sérgio Parada e Thomas Hildinger, respectivamente Presidente, Vice-Presidente e Gerente Geral de Engenharia da Voith Siemens Hydro, pela confiança no meu trabalho e pela oportunidade que me deram ao permitir a continuação dos meus estudos.

Ao Sr. Osvaldo San Martin, diretor da Voith Paper, pelo valioso apoio à implantação de uma cultura de valorização do conhecimento no grupo Voith.

Às empresas AES Eletropaulo, Camargo Corrêa e Siemens por abrirem suas portas e colaborarem com este trabalho.

Aos entrevistados, Sr. Arnaldo Silva Neto, Sr. Ricardo Achilles e Sr. Milton Romera, da empresa AES Eletropaulo; Sr. José Renato Santiago Jr. e Sr. Ronaldo Fujiwara, das empresas Camargo Corrêa e Nethighway; Sr. Filipe Cassapo, Sra. Elaine Soares, Sra. Loraine Baroni e Sra. Monika Sengberg, da empresa Siemens; por terem dedicado parte do seu tempo a este projeto. 
Aos colegas da equipe de implantação de Gestão do Conhecimento na Voith, Alexandre Lourenço, Armando Percorare, Cláudio Cinaqui, Ênio Sanches, Flávio Martins, Luiz Secco e Roberto Tanaka, pelas contribuições ao aprofundamento do tema durante nossas tardes de debate.

Aos colegas do Departamento de Engenharia de Novas Unidades da Voith Siemens Hydro pela compreensão nos momentos de ausência.

Ao Prof. Dr. Isak Kruglianskas, demais professores e colegas do programa de pós-graduação.

Ao Prof. Dr. Lino Rodrigues, pelos ensinamentos durante o período de monitoria.

Ao amigo Newton por facilitar o acesso aos entrevistados na AES Eletropaulo.

Ao Dr. Pimont e à Mamãe pelos livros, pelas trocas de conhecimentos e pelo carinho nos finais de semana em Bragança.

À minha amada esposa, Lelê, pela paciência na revisão do texto, pelo apoio, incentivo e compreensão constantes. 


\section{RESUMO}

Determinar quais os efeitos dos subsistemas componentes da estrutura organizacional na geração e disseminação do conhecimento é o objetivo principal proposto nesta pesquisa.

Para isto há necessidade de entender como o conhecimento e as informações circulam dentro das organizações, quais tipos de conhecimento são estes, quais processos são utilizados para disseminação dos novos conhecimentos adquiridos, como são gerados os conhecimentos nas organizações, como a empresa está estruturada, dentre outros temas relevantes para o estudo.

Com os dados gerais obtidos através da aplicação das entrevistas, foi elaborada uma análise qualitativa para detecção de correlação efetiva entre questões e variáveis.

O presente estudo permitiu concluir que a Estrutura Organizacional pode ter efeito substancialmente positivo sobre a Gestão do Conhecimento, principalmente quando adotadas as práticas de trabalho com equipes multidisciplinares para resolução de problemas ou projetos de melhoria e quando coexistirem sistemas de comunicação e ambiente propícios para o desenvolvimento de uma cultura de aprendizagem e compartilhamento do conhecimento através do contato pessoal, com adequado suporte de tecnologia. 


\section{ABSTRACT}

The main goal of this research is to determinate how the Organizational Design Systems can impact the generation and dissemination of knowledge.

It is necessary to understand how the information and knowledge flow within the organizations, which types of knowledge are that, which processes are used to disseminate the new generated knowledge, how the knowledge is generated within the organizations and how the organization is designed, among other relevant matters.

The raw data obtained through interviews were analyzed in order to detect an effective correlation between questions and variables.

The current study allows the conclusion that the Organizational Design have positive effect on Knowledge Management, mainly when practices of working with multidisciplinary teams are adopted to solve problems or to develop innovation projects and when suitable communication systems and environment for the development of a learning and knowledge sharing culture through face to face contacts - supported by appropriated technology - coexist. 


\section{Sumário}

CAPÍTULO 1: Introdução..................................................................... 2

1.1 Justificativa do Tema: A era do conhecimento........................................ 3

1.2 Objetivo e Questão de Pesquisa ................................................... 7

1.3 Estrutura da Dissertação................................................................ 7

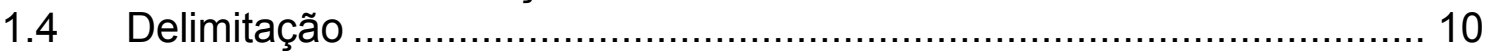

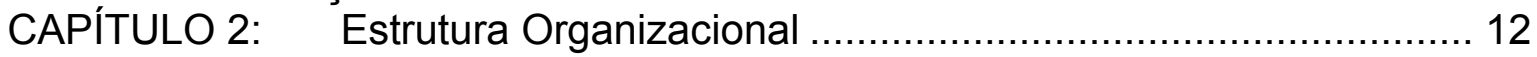

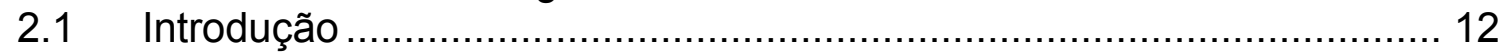

2.2 Estrutura Organizacional: conceitos básicos .................................. 14

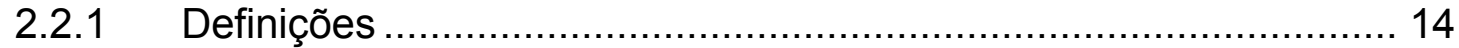

2.2.2 A Função e os Benefícios da Estrutura Organizacional .................. 16

2.3 Componentes da Estrutura Organizacional ...................................... 17

2.3.1 Nível de Formalização (Estruturas Formais e Informais) ............... 19

2.3.2 Departamentalização .................................................... 22

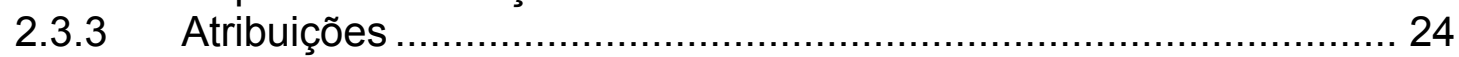

2.4 Condicionantes da Estrutura Organizacional ............................... 29

2.4.1 Fator Humano ................................................................. 30

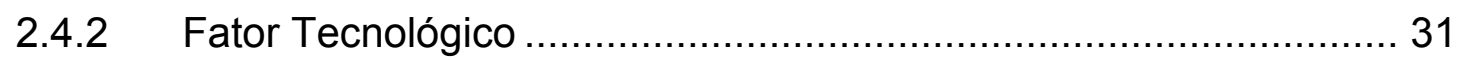

2.4.3 Fator Objetivos/Estratégia ................................................ 31

2.4.4 Fator Ecológico (Ambiente) …........................................... 31

2.5 Abordagens para Estruturas Organizacionais.................................. 32

2.5.1 Estruturas Mecanicistas e Orgânicas: O modelo de Burns e Stalker 33

2.5.2 Estruturas Tradicionais ...................................................... 36

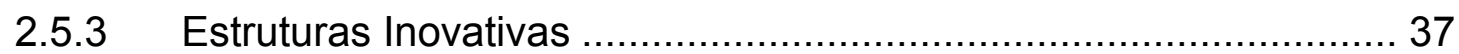

CAPÍTULO 3: Gestão do Conhecimento .................................................. 42

3.1 Introdução ....................................................................... 42

3.2 Conhecimento: Interpretações, conceitos e definições ........................ 43

3.2.1 Teoria Filosófica............................................................... 43

3.2.2 Teoria Contemporânea ......................................................... 44

3.3 Classificação do Conhecimento Organizacional ................................ 45

3.3.1 Conhecimento Tácito e Conhecimento Explícito........................... 46

3.4 Características do Conhecimento ................................................. 49

3.4.1 Dado x Informação x Conhecimento x Competência ...................... 49

3.4.2 O Ciclo do Conhecimento .................................................... 52

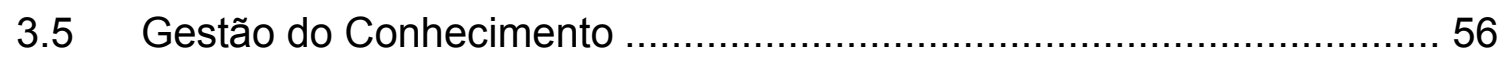

3.5.1 Mapeamento de Competências e Conhecimentos …....................... 58

3.5.2 Aprendizagem Organizacional ...........................................6 60

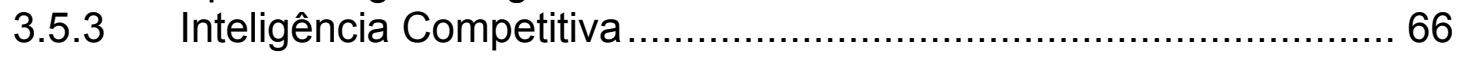

3.6 Gestão do Conhecimento: modismo, idealismo ou realidade? ..............69 69

CAPÍTULO 4: A Estrutura Organizacional Como Elemento Facilitador da Gestão do Conhecimento........................................................................... 73

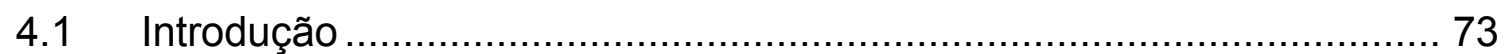

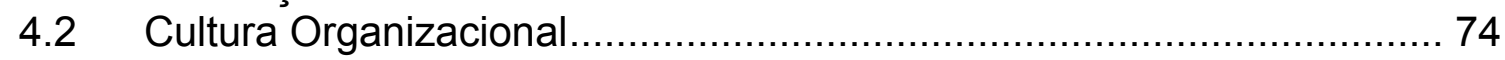

4.3 Geração de Conhecimento e Criatividade ........................................ 79

4.4 Disseminação do Conhecimento e Comunicação................................ 81

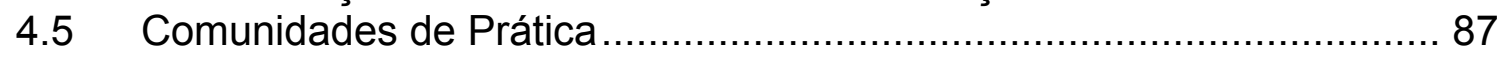

4.6 O Papel do Líder na Empresa Estruturada para o Conhecimento ......... 89

4.7 O Trabalhador do Conhecimento ...................................................... 91 
4.8 Estrutura Organizacional e Gestão do Conhecimento

4.8.1 Novos Desenhos Organizacionais: Estruturas Específicas para

Organizações do Conhecimento ........................................................ 94

4.8.2 Delegação de Poderes ......................................................... 98

4.8.3 Diretor do Conhecimento (CKO - Chief Knowledge Officer) ...........100

4.8.4 Diretoria do Conhecimento .................................................... 103

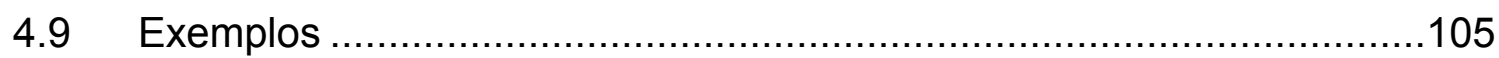

4.9.1 O Exemplo da Skandia ....................................................... 105

4.9.2 O Exemplo da BUCKMAN LABORATÓRIOS .............................108

4.9.3 Conclusão dos Exemplos ......................................................112

CAPÍTULO 5: Metodologia de Pesquisa.................................................114

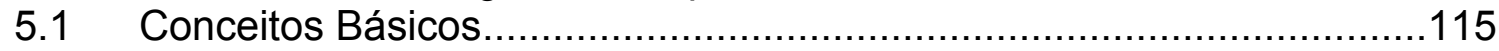

5.1.1 Tipos de Pesquisas .................................................................

5.1.2 Tipos, Fontes e Formas de Coleta de Dados ..............................117

5.2 Opção Metodológica e Delineamento da Pesquisa ............................118

5.2.1 Opção Metodológica .............................................................118

5.2.2 Delineamento da Pesquisa: Roteiro.......................................120

5.3 Modelo Conceitual: Gestão do Conhecimento ...................................121

5.4 Modelo Referencial: a Estrutura Organizacional Facilitando a Gestão do

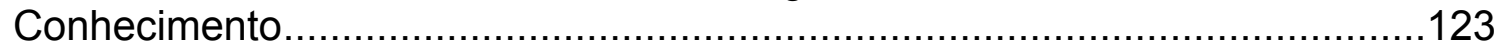

5.4.1 Definição das Variáveis ...................................................123

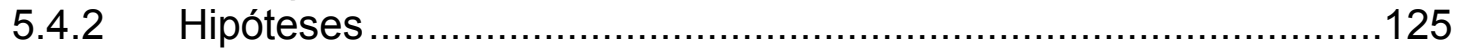

5.4.3 Procedimento de Coleta de Dados .........................................128

5.4.4 Análise de Dados ...................................................................130

5.5 Critério para Seleção dos Casos e Ambiente de Pesquisa ....................130

CAPÍTULO 6: $\quad$ Análise e Interpretação dos Dados .......................................133

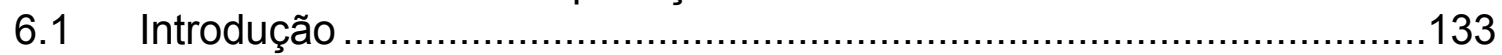

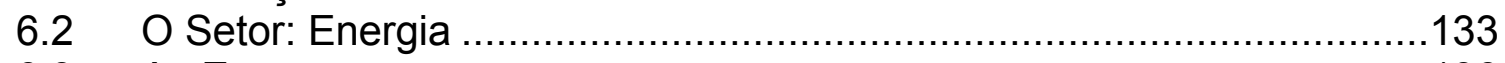

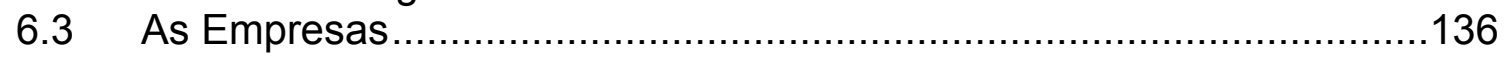

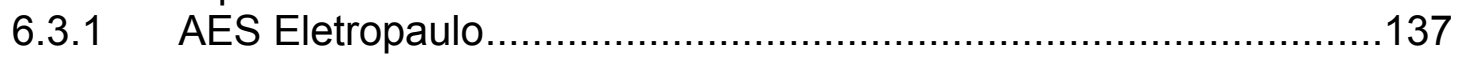

6.3.2 Camargo Corrêa ................................................................ 141

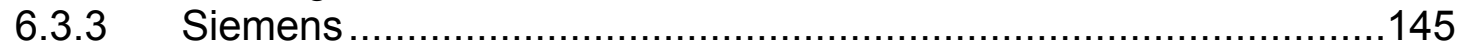

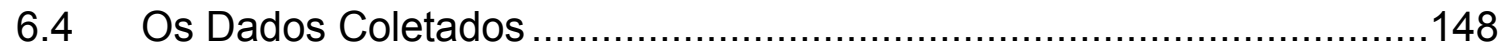

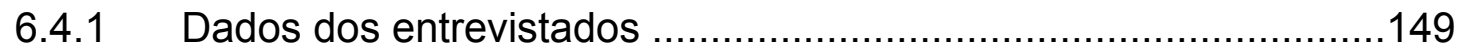

6.4.2 Cultura Organizacional .................................................... 149

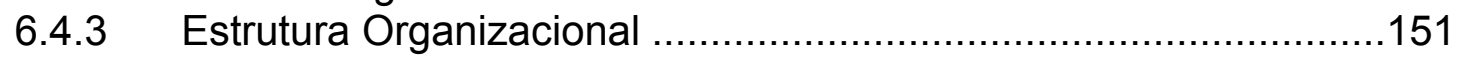

6.4.4 Aprendizagem ................................................................. 162

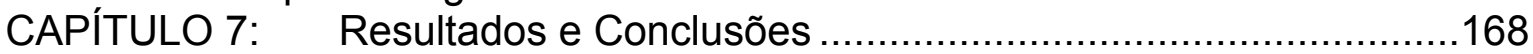

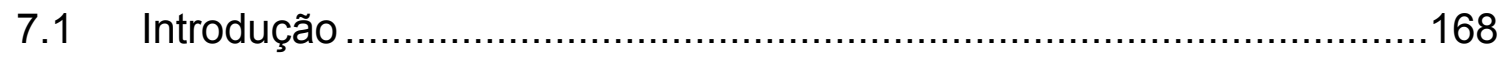

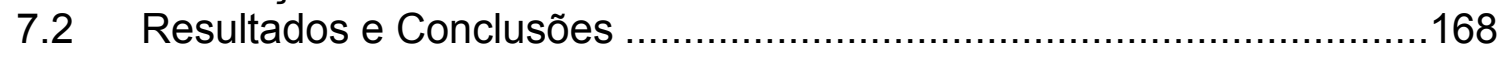

7.2.1 Nível de Formalização - Processos Formais ..............................169

7.2.2 Nível de Formalização - Espaços Físicos ....................................170

7.2.3 Critérios de Departamentalização................................................170

7.2.4 Critérios de Departamentalização - Administração do Conhecimento 171

7.2.5 Critérios de Departamentalização - Equipes Multidisciplinares.....172

7.2.6 Atribuições - Atividades (Papel do Líder) ..................................173

7.2.7 Atribuições - Níveis de Decisão ..........................................174

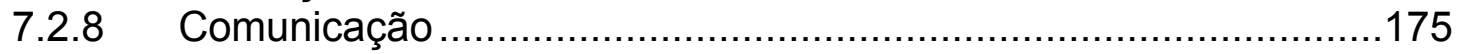

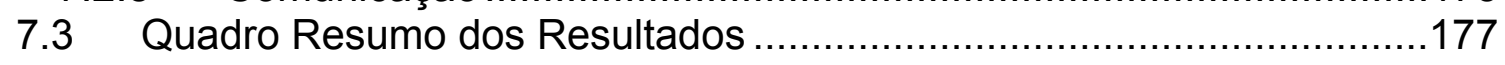




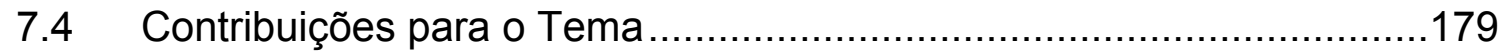

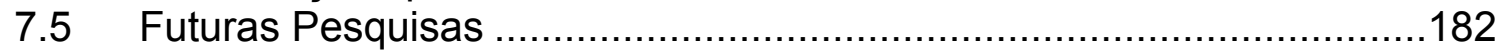

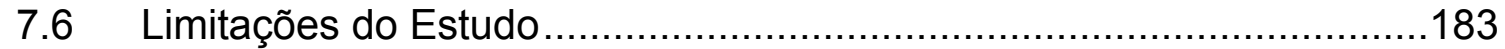

CAPÍTULO 8: Referências Bibliográficas .................................................186

8.1 Sites Pesquisados (Internet) ……...............................................192

\section{Anexos}

anexo 1: Roteiro de Entrevista

\section{Lista de figuras}

Figura 1. As Eras Econômicas ................................................................... 4

Figura 2. Estrutura da Dissertação ............................................................. 9

Figura 3. Cadeia de Valor Empresarial .................................................... 13

Figura 4. Vantagens e Desvantagens da Centralização e da Descentralização .. 23

Figura 5. Componentes e Condicionantes da Estrutura Organizacional .............. 32

Figura 6. Exemplo de Estrutura Matricial ..................................................... 38

Figura 7. O Ciclo do Conhecimento: Processo................................................. 53

Figura 8. O Ciclo da Aprendizagem Organizacional......................................... 64

Figura 9. Definição da Agenda de Competências Essenciais ............................... 69

Figura 10. Estrutura de Gestão Voltada para o Capital Intelectual......................106

Figura 11. Modelo Conceitual de Gestão do Conhecimento ...............................121

Figura 12. Modelo Referencial de Pesquisa..............................................125

Figura 13. Cultura Organizacional......................................................126

Figura 14. Nível de Formalização..........................................................126

Figura 15. Departamentalização …………………...................................127

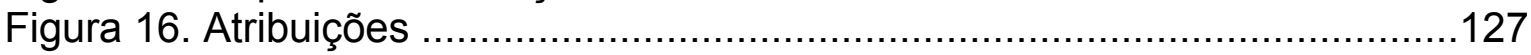

Figura 17. Aprendizagem Organizacional ...............................................128

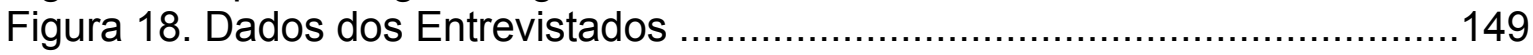

Figura 19. Quadro Resumo dos Resultados .................................................179 


\section{CAPítulo 1 \\ Introdução}

"A abelha fazendo o mel, vale o tempo que não voou."

Ronaldo Bastos e Beto Guedes 


\section{CAPÍTULO 1: Introdução}

Esta dissertação trata da influência entre os temas Estrutura Organizacional e Gestão do Conhecimento. São investigadas as relações entre eles, através da discussão, apresentação e análise da bibliografia pertinente e de levantamentos empíricos realizados com profissionais de empresas intensivas em conhecimento do setor energético.

Para integrar dois temas tão importantes e amplos, cujas raízes diferem substancialmente em termos de teorias básicas, métodos de abordagem e época de surgimento, foi necessária uma extensa e profunda revisão bibliográfica de ambos para que fosse viável determinar em quais aspectos haveriam relevantes graus de inter-relacionamento e influência. Isto feito, foi possível concentrar a atenção nos elementos escolhidos e, através da metodologia, estudar a relação entre as diversas variáveis de ambos.

Segundo Argyris (1996:6) um importante aspecto para a produção de teorias eficazes de gerenciamento é a integração das disciplinas funcionais gerenciais existentes em uma teoria mais abrangente que seja aplicável ao cotidiano das organizações; o que poderá demandar algumas alterações nas estruturas internas destas teorias, bem como na maneira de conectá-las.

A primeira seção deste capítulo introdutório apresenta a justificativa do tema. A segunda, o objetivo e a questão de pesquisa. E na terceira seção o leitor tomará contato com a estrutura da dissertação. 


\subsection{JUSTIFICATIVA DO TEMA: A ERA DO CONHECIMENTO}

Srour (1998:1) credita a Alvin Toffler a genial intuição de uma Terceira Onda quando, ainda na década de 1960, boa parte dos pesquisadores acadêmicos mal concebia o que acabou sendo denominado "Terceira Revolução Industrial". Toffler distingue-se ao afirmar que a era da chaminé (ou da máquina) foi superada. Não haveria razões para falar de civilização industrial, mas de uma economia supersimbólica, que se baseia nos computadores, na troca de dados, de informações e de conhecimento. Toffler confere, assim, um mesmo estatuto teórico às três "ondas": à atual, que denomina Terceira, e que corresponde a uma revolução da informação, à Segunda, identificada como revolução industrial; e à Primeira, entendida como revolução agrícola.

Para Stewart (1998:5) o conhecimento tornou-se um recurso econômico proeminente - mais importante que a matéria prima; mais importante, muitas vezes, que o dinheiro. Considerados produtos econômicos, a informação e o conhecimento são mais importantes que automóveis, carros, aço e qualquer outro produto da era industrial.

Drucker (2001:3) afirma que a próxima sociedade será a do conhecimento. O conhecimento será o recurso chave e os trabalhadores do conhecimento serão o grupo dominante na força de trabalho desta sociedade. Esta sociedade será a mais competitiva de todas, para as organizações e para os indivíduos.

As eras econômicas são esquematicamente mostradas na Figura 1. 


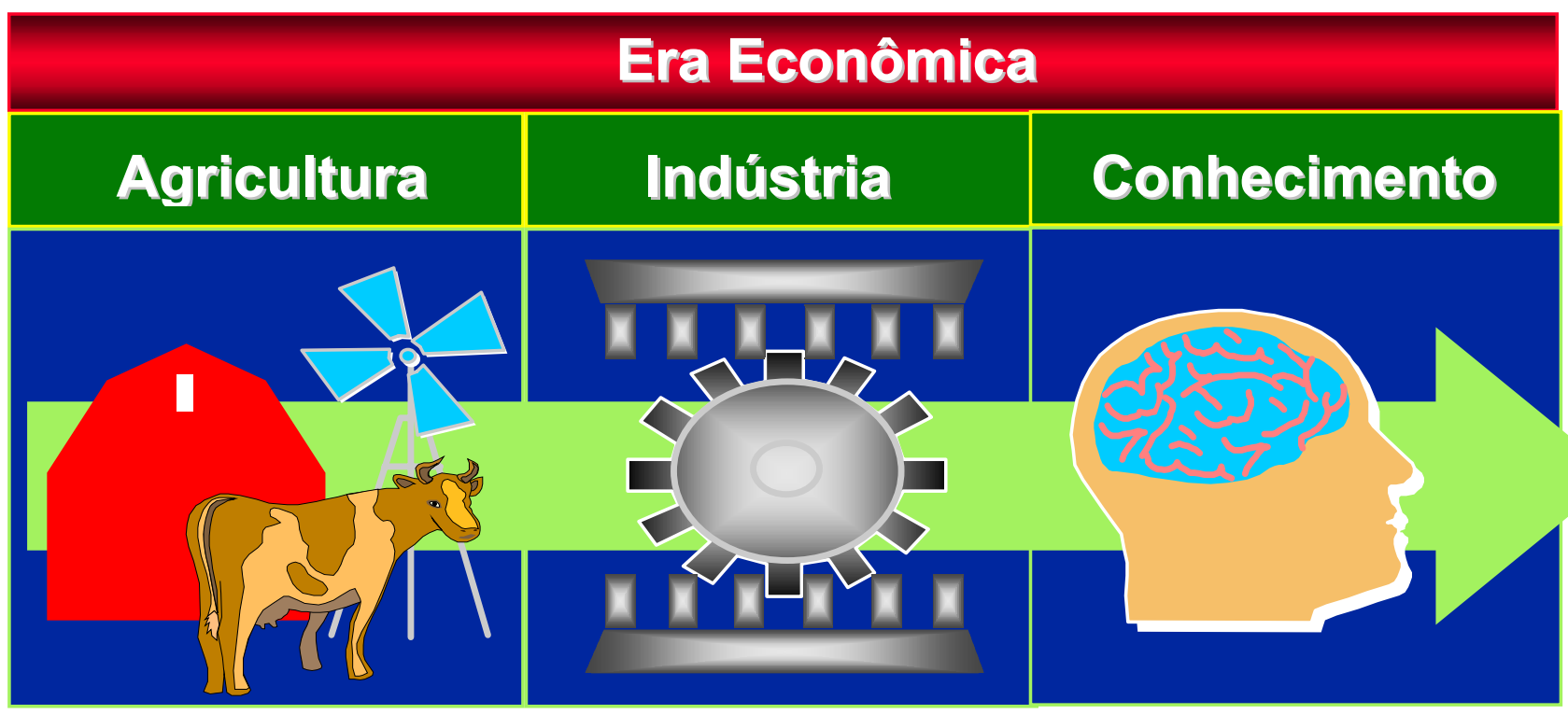

Figura 1. As Eras Econômicas

Fonte : Adaptado a partir do modelo de consultoria da Arthur D. Little Inc.

Apesar de não estar explicitamente citado no modelo apresentado acima, entende-se que a era do conhecimento compreende, ou é uma evolução, da era de Serviços e da era da Informação.

De acordo com Crawford (1994:20) a economia do conhecimento difere das suas duas predecessoras nos serviços, que são mais do que a produção de mercadorias, a forma dominante de emprego. É uma economia de processamento de informações na qual computadores e telecomunicações são elementos fundamentais e estratégicos. Pesquisa científica e educação são as bases da geração da riqueza. A organização econômica e social é centrada na posse da informação, do conhecimento e na utilização do capital humano.

Para Gates (1999:389), as eras econômicas anteriores foram marcadas por longos períodos de estabilidade, seguidos por curtos períodos de mudança. Hoje, as forças da informação digital estão criando um ambiente empresarial em constante mudança.

Fleury e Fleury (2000:37) afirmam que na economia baseada no conhecimento, o que mais adiciona valor são as atividades inteligentes. As atividades rotineiras, manuais, passam a ser cada vez menos importantes. 
Segundo Crawford (1994:30) na era econômica do conhecimento novas formas de administração de organizações são desenvolvidas, utilizando-se tecnologia intensiva e enfatizando os recursos humanos.

Para Thurow (2001:98) por milhares de anos as terras agrícolas vinham logo depois da organização social e do espírito empreendedor como bloco básico de construção na base da pirâmide de riqueza. Depois da primeira revolução industrial, os recursos de energia substituíram as terras neste papel. A seguir o conhecimento passa a ocupar a posição que anteriormente foi das terras e da energia.

Assim como estes, diversos outros autores e pesquisadores perceberam nas últimas duas décadas o crescimento da importância do conhecimento para as organizações. Com isto, surgiram muitas teorias sobre como administrar o conhecimento e sobre como administrar organizações intensivas em conhecimento, devido à necessidade dos gestores controlarem e disseminarem aquele que muitos consideram seu ativo mais valioso.

Para Crawford (1994:27) a força propulsora para a transição de uma economia industrial para economia do conhecimento é o aumento da produtividade causado por inovações em tecnologia, organização e administração.

Segundo Drucker (1998:107), terra, mão-de-obra e capital - os tradicionais fatores de produção dos economistas - não desapareceram, mas tornaram-se secundários. Eles podem ser obtidos, e com facilidade, desde que haja conhecimento especializado. Ao mesmo tempo o conhecimento especializado por si só não produz nada. Ele se torna produtivo somente quando está integrado a uma tarefa. E é por isto que a sociedade do conhecimento também é um sociedade de organizações: a finalidade e a função de cada organização, empresarial ou não, são a integração de conhecimentos especializados em uma tarefa comum. 
Drucker (1995:165) afirma serem os indivíduos fundamentais para a sociedade do conhecimento, pois o conhecimento está sempre incorporado a uma pessoa. Portanto a passagem para a sociedade do conhecimento coloca a pessoa no centro.

Para Sveiby (1997:28) a economia da era do conhecimento oferece recursos ilimitados pois a capacidade humana para criar conhecimentos é infinita.

Segundo Stewart (2001:5), prosperar nesta nova economia requer um novo vocabulário, novas técnicas de gerenciamento, novas tecnologias e novas estratégias.

Em um processo de transição da era industrial para a era pós-industrial torna-se relevante que as organizações insiram como tema fundamental de sua visão corporativa estratégica a gestão do conhecimento. É a partir da gestão desse capital intelectual que, em uma sociedade global, onde a produção física se comoditiza mais e mais, se poderá diferenciar e agregar valor aos produtos e serviços das organizações, tendo em vista a expansão de seus negócios e conseqüentemente, do incremento patrimonial das empresas.

O desenvolvimento intenso de novas tecnologias, a contínua inovação dos produtos e a necessidade de melhorar a competitividade para atender uma demanda de mercado cada vez mais sofisticada, exigem das organizações a busca permanente do conhecimento novo pelo homem, muito além do pensamento tradicional. Compõe-se, assim, uma economia ágil, na qual as empresas estão cada vez mais dependentes de sua capacidade de inovar.

Estruturar convenientemente organizações que necessitem gerir conhecimento revela-se como vital para clientes, empregados, acionistas e quaisquer outros associados em um mundo de negócios que se modifica em seus valores, mas que na sua essência depende do intelecto e dos conhecimentos do homem para atingir a excelência. A gestão própria desse ativo organizacional, tratado via de regra como um bem intangível, torna-se mandatória na gestão das corporações modernas. 
Portanto, neste contexto, pode-se afirmar ser de vital importância o avanço na construção de conhecimento:

> sobre como transformar conhecimento em instrumento para o sucesso, o crescimento e a perpetuidade de organismos e nações e;

$>$ sobre como criar ou adaptar estruturas e sistemas existentes para esta nova era.

\subsection{OBJETIVO E QUESTÃO DE PESQUISA}

Mesmo com a quantidade de publicações sobre o tema Gestão do Conhecimento crescendo nos últimos anos em progressão geométrica, ainda existe dificuldade em encontrar trabalhos que tragam à luz e discutam argumentos que nos levem a entender como a estrutura organizacional pode atuar como elemento facilitador da administração do conhecimento.

Desta forma, a dissertação tem como objetivo principal responder à seguinte questão de pesquisa:

Quais os efeitos dos subsistemas componentes da estrutura organizacional na geração e disseminação do conhecimento?

Os temas referentes a este objetivo serão tratados na revisão bibliográfica, nos capítulos 2 a 4 , serão utilizados como guias do instrumento de coleta de dados e orientarão a análise dos resultados e as conclusões.

\subsection{ESTRUTURA DA DISSERTAÇÃO}

Este trabalho está estruturado em 8 capítulos. Abaixo são descritos os capítulos: seus títulos e uma pequena explicação dos temas a serem abordados. Em seguida, na Figura 2, apresenta-se a estrutura da dissertação de forma gráfica. 
Capítulo 1: INTRODUÇÃO. Neste capítulo descreve-se a formulação do problema, as questões de pesquisa, os objetivos, a justificativa do tema e a estrutura da dissertação.

Capítulo 2: ESTRUTURA ORGANIZACIONAL. Nesse capítulo inicia-se a revisão bibliográfica. São apresentados os conceitos básicos, a função e os benefícios da estrutura organizacional, seus componentes e condicionantes. Prossegue-se discutindo as principais abordagens dos autores para estruturas organizacionais, contemplando-se estruturas tradicionais bem como os modos alternativos de organização.

Capítulo 3: GESTÃO DO CONHECIMENTO. Esse capítulo trata da revisão bibliográfica deste outro tema. São abordadas inicialmente as diferentes interpretações, conceitos e definições para o conhecimento. Em seguida comenta-se os tipos e características do conhecimento sob a ótica de diversos autores.

\section{Capítulo 4: A ESTRUTURA ORGANIZACIONAL COMO ELEMENTO} FACILITADOR DA GESTÃO DO CONHECIMENTO. Aqui é debatida a relação entre os dois temas. Identificando-se quais elementos da estrutura organizacional relacionam-se com os diversos fatores da gestão do conhecimento. Temas como disseminação do conhecimento, comunicação, compartilhamento de informações, são vistos sob as duas perspectivas e relacionados convenientemente.

Capítulo 5: METODOLOGIA DE PESQUISA. Esse capítulo trata da metodologia aplicada à pesquisa. As opções metodológicas, a seleção das organizações, o planejamento e execução do estudo de campo.

Capítulo 6: ANÁLISE E INTERPRETAÇÃO DOS DADOS. Neste capítulo descreve-se a pesquisa realizada, o setor, as empresas e os dados primários e secundários coletados.

Capítulo 7: RESULTADOS E CONCLUSÕES. Análises, contribuições para o tema, futuras pesquisas, limitações. 
Capítulo 8: BIBLIOGRAFIA.

Capítulo 1: Introdução

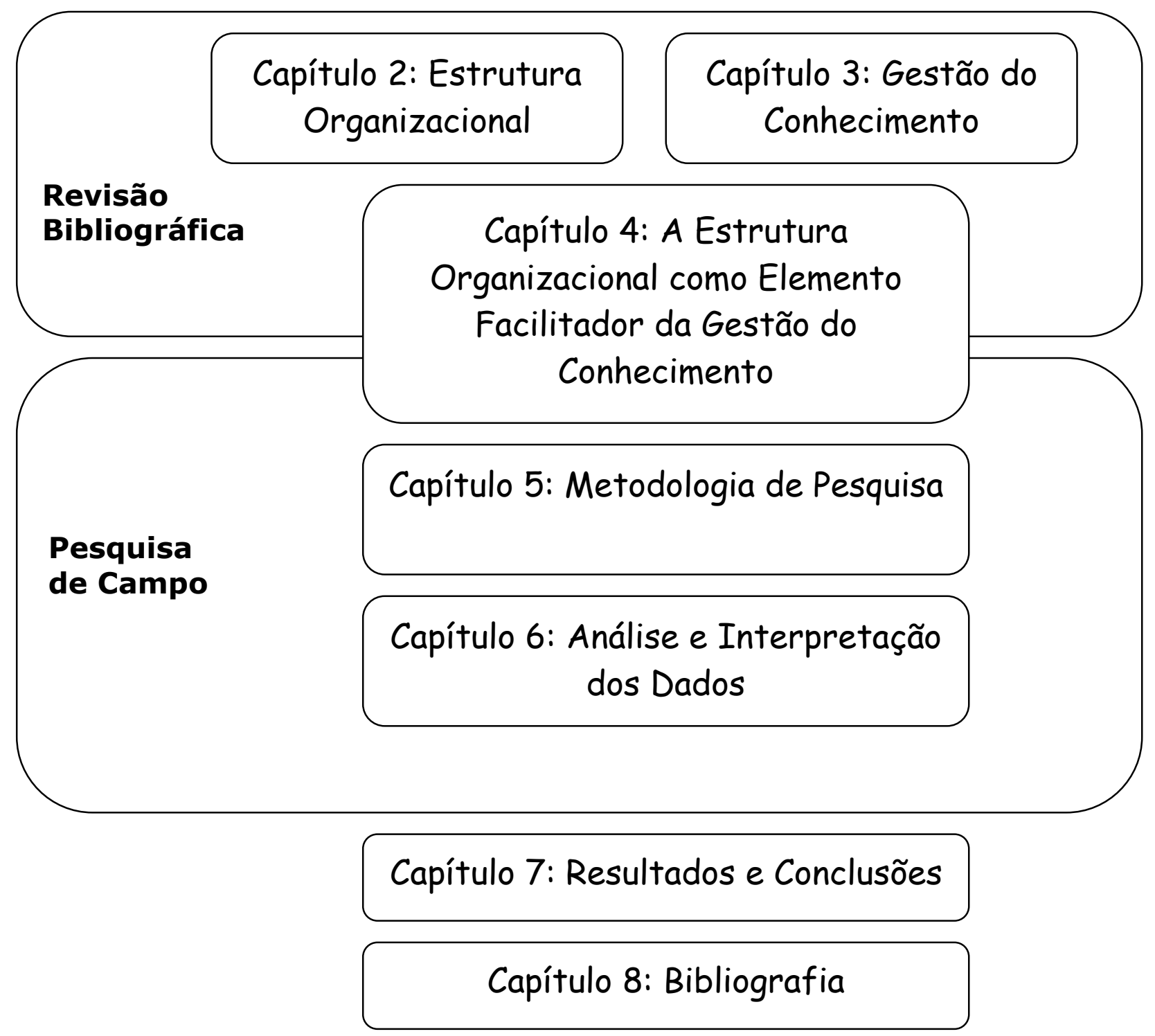

Figura 2. Estrutura da Dissertação

Fonte : Elaborado pelo autor 


\subsection{DELIMITAÇÃO}

O estudo concentrou-se na análise da inter-relação entre os temas Estrutura Organizacional e Gestão do Conhecimento. Em particular dentro do tema Estrutura Organizacional optou-se por estudar os Níveis de Formalização, os Critérios de Departamentalização, as Atividades, os Níveis de Decisão e a Comunicação. Dentro do tema Gestão do Conhecimento, o foco foi dado na Aprendizagem Organizacional. Detalharam-se mais especificamente os componentes Geração e Disseminação do ciclo do conhecimento.

O estudo restringe-se às empresas que atuem no setor de Energia. A justificativa para a delimitação da pesquisa a este setor da economia será abordada no capítulo 5. 


\section{CAPÍtULO 2}

\section{Estrutura Organizacional}

"Todo homem é do tamanho do seu sonho." 


\section{CAPÍTULO 2: Estrutura Organizacional}

\subsection{INTRODUÇÃO}

A estrutura organizacional deve ser definida consoante a estratégia de negócios das organizações. A escolha de uma estrutura em detrimento de outra inevitavelmente envolve vantagens e desvantagens, privilegiando certos aspectos comparativamente a outros. A questão importante a abordar em qualquer estratégia de gestão é que se focalize nos aspectos mais relevantes e, dessa forma, provenha as condições necessárias para que sejam alcançados. Em geral, a administração dessa estrutura deve buscar concentrar-se na cadeia de valor horizontal dos negócios : a gestão de suprimentos, produção, comercialização, finanças; e na gestão dos talentos humanos, assim como estar absolutamente focada na gestão da cadeia de valor vertical do setor onde a empresa atua: seu macro segmento, conforme mostra a Figura 3 .

As estruturas organizacionais, como será mostrado ao longo deste capítulo, já foram alvo de estudo de diversos autores. Sobrevoando estas teorias, pesquisas e estudos deste ramo da Administração constata-se que os desenhos organizacionais moldaram-se às condições de contorno da época e às circunstâncias em que foram utilizados.

A proposta deste capítulo é apresentar os principais conceitos que envolvem as teorias das estruturas organizacionais e alguns tipos de estruturas das organizações, contrapondo opiniões de diversos autores. 


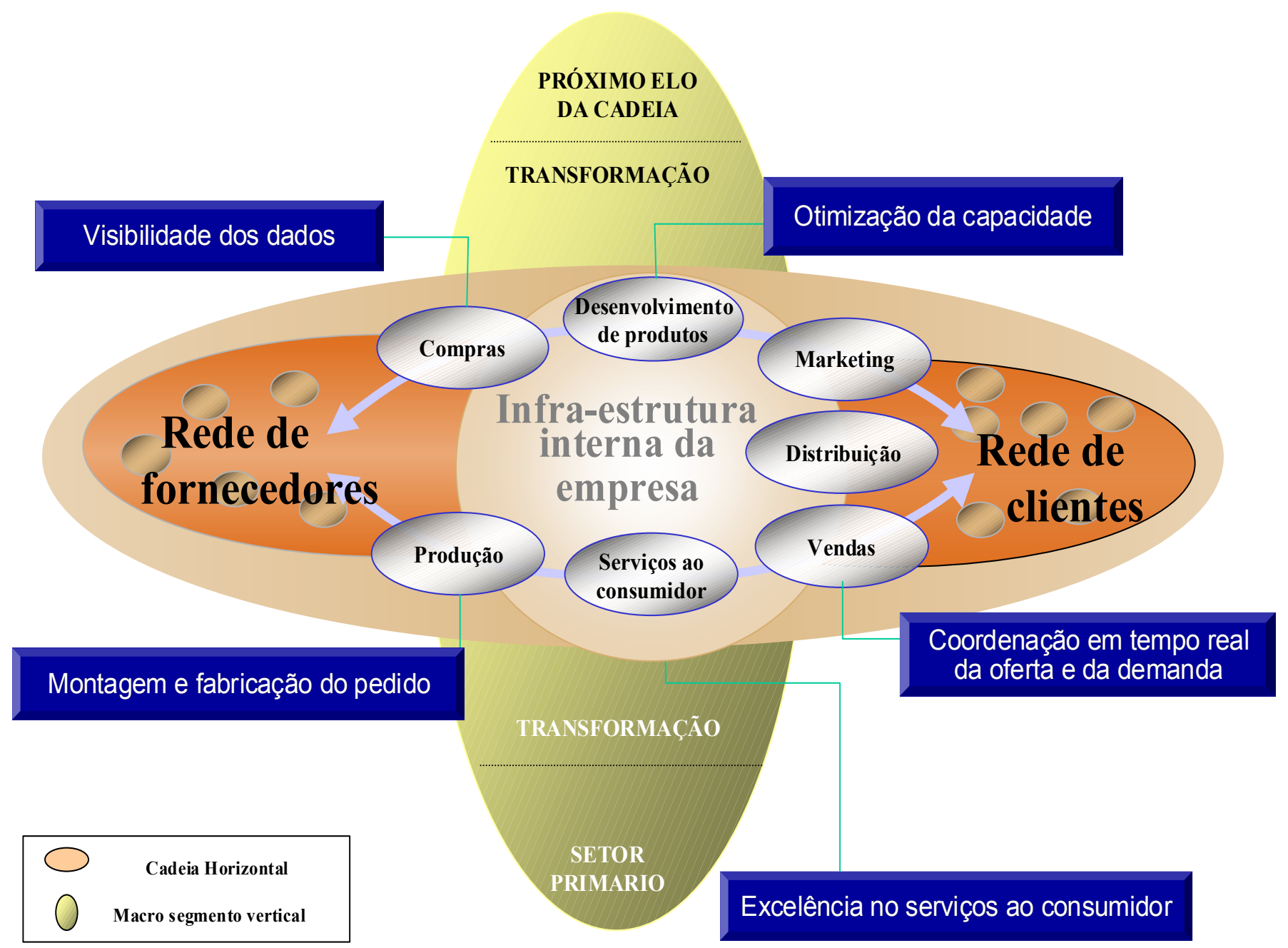

Figura 3. Cadeia de Valor Empresarial

Fonte : Adaptado a partir do modelo de consultoria da PricewaterhouseCoopers visando refletir os componentes da cadeia de realização horizontal dos negócios, interagindo com a dinâmica da nova economia, onde o Capital Intelectual é um componente chave da gestão. 


\subsection{ESTRUTURA ORGANIZACIONAL: CONCEITOS BÁSICOS}

\subsubsection{Definições}

Tratando este capítulo de organizações e suas estruturas, deve-se conceituar, mesmo que brevemente, alguns termos que serão recorrentes ao longo deste texto.

Muitos foram os autores que externaram seus pontos de vista e suas definições a respeito de organização e estrutura organizacional. Por não ser este o objetivo primeiro deste capítulo, relacionaram-se as definições que mais se aproximam do presente estudo.

Galbraith (1977:3) define organização como uma composição de pessoas com a finalidade de alcançar algum propósito compartilhado através da divisão do trabalho, integrado por processos de decisão baseados em informações, continuamente através do tempo.

Segundo Vasconcellos (1989:3) a estrutura de uma organização pode ser definida como resultado de um processo através do qual a autoridade é distribuída, as atividades desde os níveis mais baixos até a Alta Administração são especificadas e um sistema de comunicação é delineado permitindo que as pessoas realizem as atividades e exerçam a autoridade que lhes compete para atingir os objetivos organizacionais.

Para Oliveira (2000:85) a estrutura organizacional é o conjunto ordenado de responsabilidades, autoridades, comunicações e decisões das unidades organizacionais de uma empresa.

Maximiano (1986:153) explica que para juntar todas as tarefas especializadas, é necessário estabelecer uma rede de relações entre indivíduos ou grupos de indivíduos, de forma que seus trabalhos sejam coordenados e coerentes com a tarefa final. Esta estrutura de coordenação chama-se estrutura organizacional. A estrutura organizacional, portanto, é o produto das decisões de divisão e coordenação do trabalho, e define não apenas as atribuições 
específicas, mas também o modo como devem estar interligados os diversos grupos especializados, chamados departamentos.

Na opinião de Robbins (2002:401), um pesquisador do comportamento humano da Universidade do Arizona, as organizações possuem estruturas diferentes, que têm impacto sobre as atitudes e comportamentos de seus funcionários. A estrutura organizacional define como as tarefas são formalmente distribuídas, agrupadas e coordenadas.

Segundo Myers (1996:2), a performance da organização é o resultado da interação da estratégia, contexto organizacional e comportamento individual. Com o risco da supersimplificação, isto significa que gerentes precisam escolher a abordagem certa para os mercados certos, criar processos para fornecer produtos e/ou serviços de qualidade para estes mercados, e motivar pessoas para agir alinhadas com os objetivos da empresa. A elaboração da estrutura organizacional leva em consideração três fatores críticos de sucesso: estratégia, organização e motivação. Na sua essência esta abordagem presume que as ações de uma pessoa são influenciadas pela situação dela. Muitas práticas derivadas desta tradição são baseadas na crença que empresas atingem uma performance eficaz, alinhando, ou tornando consistente, diversos componentes organizacionais. Intervenções na estrutura organizacional tratam de modificar elementos da estrutura de uma organização, incluindo a divisão do trabalho, a alocação dos poderes de decisão, escolhas dos mecanismos de coordenação, delineamento das fronteiras da organização e redes de relacionamentos informais.

A estrutura organizacional, acrescenta o autor, versa sobre facilitar que um grupo de pessoas combine, coordene e controle recursos e atividades a fim de produzir valor, tudo de maneira apropriada ao ambiente onde a empresa compete.

Galbraith (1977:5) argumenta que o conceito de estrutura organizacional resulta da combinação da definição de organização e do conceito de escolha estratégica. A estrutura organizacional é concebida para ser um processo de decisão para trazer coerência entre os objetivos e propósitos para os quais a 
organização existe, o modelo de divisão do trabalho e de coordenação entre unidades e as pessoas que farão o trabalho.

Para Pinto (2002:42) é relevante notar que a estrutura organizacional influencia significativamente a performance da organização.

\subsubsection{A Função e os Benefícios da Estrutura Organizacional}

Segundo Oliveira (2000:81) quando a estrutura organizacional é estabelecida de forma adequada, ela propicia para a empresa alguns aspectos:

> Identificação das tarefas necessárias;

> Organização das funções e responsabilidades;

Informações, recursos e feedback aos empregados;

Medidas de desempenho compatíveis com os objetivos; e

Condições motivadoras.

Para Child (citado por Chiavenato, 1999:664), o desenho de uma organização constitui uma das maiores prioridades da administração, pois a função da estrutura organizacional é auxiliar no alcance dos objetivos organizacionais servindo como:

> Estrutura básica - ao contribuir para a implementação de planos bem como para a alocação de pessoas e de recursos para as tarefas que precisam ser feitas e ao proporcionar mecanismos para a coordenação dessas tarefas. Nessa circunstância, assume a forma de descrições de cargos, organogramas, constituição de conselhos e de comissões;

Mecanismo de operação - ao indicar com clareza aos membros da organização o que deles é esperado através de elementos normativos como procedimentos de trabalho, padrões de 
desempenho, sistema de avaliação, sistema de recompensas, programações e sistemas de comunicação;

Mecanismo de decisão - suportando o processo de tomada de decisão e seus requisitos de processamento de informação, o que inclui o fornecimento de arranjos favoráveis à obtenção de informações do meio externo e procedimentos para tratamento de informações.

\subsection{COMPONENTES DA ESTRUTURA ORGANIZACIONAL}

A seguir são apresentadas as visões de diversos autores com relação aos componentes da estrutura organizacional.

Em sua tese, Vasconcellos (1972:145) entende por componentes estruturais as variáveis cujas configurações precisam ser determinadas para que a estrutura possa ser montada. Estes componentes são:

Formas da Estrutura. São as várias alternativas de configuração que a estrutura da organização pode apresentar. Entre estas configurações temos: Funcional, Linha-Staff, Comissões, Inovativa, Matriz. Muito raramente essas configurações são encontradas de forma pura, na maior parte dos casos as estruturas são constituídas por combinações dessas formas principais.

Divisões da Estrutura. São os aglomerados em que a organização é dividida. Uma alternativa para a composição de uma estrutura pode ser: Divisões Administrativas, formadas por departamentos, que são conjuntos de seções que são formadas por unidades administrativas.

Sistema de Comunicação. É necessário para que a estrutura administrativa exista como um sistema integrado. 
Amplitude Administrativa. Existe um limite relativo ao número de pessoas que o chefe pode supervisionar eficientemente. Este número é chamado de Amplitude Administrativa.

Autoridade e Responsabilidade.

Alguns anos depois, em seu livro, Vasconcellos (1989:4) condensa alguns itens e sugere um modelo no qual a estrutura organizacional é composta dos subsistemas de autoridade, comunicação e atividades.

Oliveira (2000:90-99), concorda com Vasconcellos e descreve como componentes da estrutura organizacional os sistemas de responsabilidades (análogo ao subsistema de atividades de Vasconcellos), de autoridade, de comunicações e, ainda acrescenta mais um, denominando de sistema de decisões.

Para Robbins (2002:401) existem seis elementos básicos a serem focados pelos administradores quando projetam a estrutura de suas organizações. São eles a especialização do trabalho, a departamentalização, a cadeia de comando, a amplitude de controle, a centralização e descentralização e a formalização.

Mais recentemente Vasconcellos (2003) adota um novo modelo conceitual para definição dos componentes da estrutura organizacional:

Nível de formalização;

$>$ Departamentalização e;

$>$ Atribuições.

Foi adotado nesta dissertação o modelo desenvolvido por Vasconcellos (2003) pelo fato dos seus subsistemas coincidirem ou englobarem os componentes citados pelos demais autores. Esta escolha facilitará a referência desses componentes em capítulos posteriores. Nos parágrafos seguintes apresenta-se cada um dos componentes da estrutura organizacional e suas 
subdivisões. Algumas subdivisões poderiam ser alocadas em mais de um componente, porém adotou-se o princípio da predominância para evitar repetição.

\subsubsection{Nível de Formalização (Estruturas Formais e Informais)}

Este tópico é o de maior convergência de opiniões entre os autores. Praticamente todos admitem a existência de uma estrutura informal nas organizações, independente do tipo de estrutura formal adotada.

Segundo Vasconcellos (1989:7), a estrutura formal é aquela explicitada em manuais de organização que descrevem os níveis de autoridade e responsabilidade dos vários departamentos e seções. A representação gráfica da estrutura formal é feita através do organograma.

A escola clássica da Administração achava que as organizações operavam somente através da estrutura formal. Entretanto, vários fatores concorrem para tornar inviável esta premissa:

é praticamente impossível elaborar um conjunto de normas que cubra todas as possíveis situações;

há necessidade de soluções rápidas para responder a situações críticas;

características do fator humano com respeito à liderança e objetivos pessoais influem de maneira intensa na operação da estrutura.

Assim, muitas vezes a organização opera de forma diferente daquela estabelecida, dando origem à estrutura informal. Quando funcionários de diferentes departamentos encontram-se socialmente, eles trocam informações sobre assuntos da empresa sem passar através dos canais formais de comunicação. Quando um subordinado influi sobre a decisão do chefe de forma sistemática devido à sua habilidade de relacionamento pessoal, ele está invertendo a estrutura formal. 
Pinto (2002:41) enfatiza que não se pode ignorar que a distribuição de autoridade e responsabilidades pressupõe também o estabelecimento de canais de comunicação e dá origem a arranjos de controle de comportamentos dentro da organização que em última instância visam influenciar a performance organizacional.

Revela notar que essa distribuição é feita tanto de modo formal quanto informal: na medida que é feita formalmente gera a definição e a publicação de especificações acerca de atribuições, poderes e relações de subordinação bem como de padrões de comportamentos esperados para os membros da organização, enquanto realização informal cria redes de relacionamentos interpessoais que podem influenciar o processo decisório. Neste contexto, a formalização representa a expressão dos desejos dos dirigentes no sentido de balizar o funcionamento da organização ao passo que a influência informal representa principalmente a expressão dos desejos dos membros da organização localizados em grupos informais.

Para Oliveira (2000:82) a estrutura informal é a rede de relações sociais e pessoais que não é estabelecida ou requerida pela estrutura formal. Surge da interação social, o que significa que se desenvolve espontaneamente quando as pessoas se reúnem, portanto apresenta relações que usualmente não aparecem no organograma. A primeira característica da estrutura informal é não poder ser extinta. Há muitas estruturas informais dentro de uma grande empresa. Elas existem em todos os níveis. Algumas estão inteiramente dentro da empresa; outras são parcialmente externas à empresa.

Segundo Duguid e Brown (2001:73), o papel da organização é criar processos e estruturas, para levar vantagem das práticas que se desenvolvem espontaneamente em seu interior.

O autor elenca ainda algumas vantagens da estrutura informal:

proporciona maior rapidez no processo;

reduz distorções existentes na estrutura formal; 
reduz a carga de comunicação dos chefes; e

motiva e integra as pessoas da empresa.

As principais desvantagens são:

desconhecimento das chefias;

dificuldade de controle; e

possibilidade de atrito entre as pessoas.

De maneira resumida o autor apresenta alguns fatores que condicionam o aparecimento dos chamados grupos informais:

os interesses comuns que se desenvolvem em certo número de pessoas e que, por meio deles, passam a sintonizar-se mais intimamente;

> a interação provocada pela própria estrutura formal;

os defeitos da estrutura formal;

a flutuação do pessoal dentro da empresa, a qual provoca, normalmente, a alteração dos grupos sociais informais;

$>$ os períodos de lazer; e

a disputa de poder.

Por último, a estrutura informal será bastante desenvolvida e bem utilizada quando:

$>$ os objetivos da empresa forem idênticos aos objetivos dos indivíduos;

> existir habilidade das pessoas em lidar com a estrutura informal. 


\subsubsection{Departamentalização}

O subsistema de departamentalização é composto pelos Critérios de Departamentalização, Centralização e Descentralização de áreas de apoio, Amplitude Administrativa e Níveis Hierárquicos. O produto da departamentalização é o organograma.

Critérios de Departamentalização. Vasconcellos (1986:9) afirma ser departamentalização o processo através do qual as unidades são agrupadas em unidades maiores e assim sucessivamente até o topo da organização, dando origem aos diversos níveis hierárquicos.

Segundo Robbins (2002:403) a base para o agrupamento das tarefas é a departamentalização. Uma das formas mais populares de agrupamento de atividades se dá pelas funções desempenhadas: engenharia, contabilidade, produção, compras. Muitas empresas utilizam a departamentalização por produto: sabonete, creme dental, sabão em pó. Pode ocorrer também a divisão por critérios geográficos: região sul, região norte. Ou ainda a departamentalização por processos: fundição, caldeiraria, usinagem, montagem.

Para Oliveira (2000:114), departamentalização é o agrupamento, de acordo com um critério específico de homogeneidade, das atividades e correspondentes recursos (humanos, financeiros, materiais e equipamentos) em unidades organizacionais. Além das formas de departamentalização citadas por Robbins, Oliveira propõe as seguintes: por quantidade, territorial, por produtos (ou serviços), por clientes, por projetos, matricial e mista.

Centralização ou Descentralização. Segundo Souza (1982:64) a centralização diz respeito à distribuição de poder na organização, no que se refere ao processo de tomada de decisões, e à parcela de influência que detém nesse processo cada um dos indivíduos que a compõe. Normalmente um alto grau de centralização reflete a visão de que o grupo necessita de supervisão rigorosa, não estando apto a tomar decisões sobre tarefas que Ihes dizem respeito. 
Para Oliveira (2000:190), descentralização é a menor concentração do poder decisório na alta administração da empresa, sendo, portanto, mais distribuído pelos seus níveis hierárquicos. Ela pode levar ainda a um aumento da produtividade pois:

A amplitude e/ou profundidade dos cargos crescem;

As pessoas são solicitadas a aceitar maior responsabilidade;

As perícias em decisão aumentam com a prática e a liberdade para aprender por meio dos enganos cometidos; e

As empresas podem responder mais rapidamente às necessidades dos empregados e dos clientes.

No quadro a seguir, Maximiano (citado por Pinto, 2002:61) apresenta algumas vantagens e desvantagens da centralização e da descentralização.

\begin{tabular}{|c|c|c|}
\hline & VANTAGENS & DESVANTAGENS \\
\hline 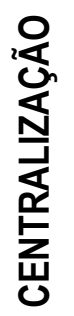 & $\begin{array}{l}\text { - produz uniformidade e facilita o } \\
\text { controle. } \\
\text { - os gerentes têm acesso rápido à } \\
\text { informação e podem cuidar dos } \\
\text { problemas à medida que ocorrem. } \\
\text { - reduz a duplicação de esforços. }\end{array}$ & $\begin{array}{l}\text { - a avaliação de desempenho sempre } \\
\text { depende de critérios estabelecidos pela } \\
\text { hierarquia superior. } \\
\text { - a busca da uniformidade desfavorece a } \\
\text { competição. } \\
\text { - tende a inibir a iniciativa e desestimular a } \\
\text { criatividade. }\end{array}$ \\
\hline 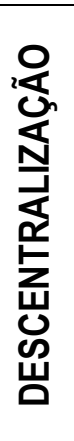 & $\begin{array}{l}\text { - permite avaliar os gerentes com base } \\
\text { em sua capacidade de tomar decisões e } \\
\text { resolver problemas. } \\
\text { - tende a aumentar a satisfação dos } \\
\text { gerentes com o sistema de controle e } \\
\text { resultado. } \\
\text { - produz um clima de competitividade } \\
\text { positiva dentro da organização. } \\
\text { - favorece a criatividade e a } \\
\text { engenhosidade na busca de soluções } \\
\text { para problemas. }\end{array}$ & $\begin{array}{l}\text { - o controle e o tratamento uniformizado de } \\
\text { problemas são difíceis em um sistema } \\
\text { descentralizado. } \\
\text { - pode diminuir as vantagens da } \\
\text { especialização devido à tendência à auto- } \\
\text { suficiência. }\end{array}$ \\
\hline
\end{tabular}

Figura 4. Vantagens e Desvantagens da Centralização e da Descentralização Fonte : Maximiano citado por Pinto (2002:61)

Amplitude Administrativa. Vasconcellos (1972:6) explica que quanto mais a firma cresce, mais empregados e supervisores são contratados, passando a 
estrutura a ter um número maior de níveis. Isto acontece porque existe um limite relativo ao número de pessoas que o chefe pode supervisionar eficientemente. Esse número é chamado de amplitude administrativa e pode variar caso a caso.

Oliveira (2000:200) concorda com Vasconcellos e afirma ainda que à medida que uma pessoa sobe numa estrutura organizacional, sua amplitude de controle torna-se menor. Ocorre também que, no mesmo nível hierárquico haverá uma considerável variação na amplitude administrativa. De qualquer forma existe relação entre amplitude administrativa e níveis hierárquicos, pois, quanto maior o número de subordinados do chefe, menor será o número de níveis hierárquicos, e vice-versa.

Níveis Hierárquicos. Segundo Oliveira (2000:203) os níveis hierárquicos representam o conjunto de cargos na empresa com o mesmo nível de autoridade. No delineamento dos níveis hierárquicos, deve-se partir do topo da pirâmide e parar no momento em que as linhas hierárquicas atingirem o nível das unidades organizacionais, que têm apenas sua vinculação eventualmente modificada, permanecendo inalteradas suas atribuições fundamentais.

\subsubsection{Atribuições}

Os principais aspectos deste subsistema são as Atividades, os Níveis de Decisão, Delegação, Atribuições das Unidades Administrativas e o Sistema de Comunicações. O subsistema de atribuições está intimamente ligado à distribuição de poder na organização. Os produtos da definição de atribuições são a lista de atribuições e o organograma linear. Para maiores detalhes sobre o organograma linear ver Vasconcellos, Kruglianskas e Sbragia (1981), Vasconcellos (1989:189) e Oliveira (2000:120).

Atividades. Pode-se classificar as atividades em dois grupos principais: atividades de linha e atividades de assessoria. Oliveira (2000:148) afirma existirem duas formas de diferenciar as atividades de linha e assessoria nas empresas. Na primeira forma considera-se que as unidades organizacionais de linha têm ações de comando, enquanto as unidades organizacionais de assessoria não têm ação de comando, pois apenas aconselham as unidades de 
linha no desempenho de suas atividades. A outra forma de apresentar a diferenciação é considerar as unidades organizacionais de linha como ligadas às atividades-fim da empresa, enquanto as unidades organizacionais de assessoria como ligadas às atividades-meio da empresa.

Para Engeström (citado em Choo, 2003:352) uma característica fundamental do sistema de atividades é a maneira como múltiplas mediações regulam as interações entre os elementos: ferramentas e conceitos mediam as interações entre o indivíduo e o seu contexto; tradições, rituais e regras fazem a mediação entre o indivíduo e sua comunidade; e uma divisão do trabalho faz a mediação entre a comunidade e as ações de seus membros.

Para Choo (2003:381) as organizações são sistemas de atividades socialmente distribuídas e atividades que interagem de acordo com as teorias de ação comuns. As interações entre indivíduos, grupos e padrões de ação são mediadas por regras, papéis e ferramentas definidos em parte pela organização, mas que também surgem naturalmente das práticas sociais e técnicas do sistema de atividade.

Níveis de Decisão. Robbins (2002:127) define decisão de maneira simples e direta: a escolha feita entre duas ou mais alternativas.

Drucker (citado por Oliveira, 2000:94) apresenta duas regras relacionadas ao nível hierárquico onde deve ser tomada a decisão:

A decisão deve ser tomada sempre no nível mais baixo possível e o mais perto possível da cena de ação;

A decisão deve ocorrer sempre em um nível que assegure a consideração plena de todos os objetivos e atividades afetados.

Neste ponto torna-se interessante relacionar os direitos de decisão com o conhecimento. Ou seja, quais seriam as dificuldades e efeitos para performance da empresa quando o poder de decisão está distante daqueles que têm o domínio do conhecimento. 
Para Vasconcellos (1989:4), quando as decisões estão excessivamente centralizadas no topo da hierarquia tem-se demora nas decisões e frustrações, sobrecarga na alta administração e decisões desvinculadas da realidade. Por outro lado, se as decisões estão excessivamente descentralizadas tem-se falta de coordenação e dificuldade de controle.

Ao abordar a importância do conhecimento na questão da definição da autoridade, Jensen e Meckling (1996:19) colocam que quando o conhecimento é valioso no momento da decisão, existem benefícios em posicionar o poder de decisão próximo ao conhecimento que é valioso para esta decisão. Existem 2 maneiras de resolver a questão. A primeira é levando o conhecimento para aqueles com poder de decisão, a outra é levar o poder de decisão para aqueles com conhecimento. A segunda recebeu sempre menos atenção dos pesquisadores que a primeira.

A questão pode também ser resolvida em termos de custos. O que é mais caro, levar o conhecimento ou o poder de decisão?

Delegação. Para Sisk (citado por Vasconcellos, 1972:147), delegação é um processo administrativo que permite a transferência de autoridade do superior para o subordinado. Vasconcellos (1972:147) prossegue afirmando que ao delegar, o chefe transfere parte de sua autoridade aos subordinados. É fundamental que ele tenha capacidade de delegar sem perder o poder, caso contrário ele despenderá tantas energias disputando a liderança com os subordinados que terá dificuldade em supervisionar um grande número deles.

Oliveira (2000:182) concorda com Vasconcellos e acrescenta que na atribuição de tarefas aos indivíduos, deve-se tomar medidas para a continuidade do desempenho das tarefas assim delegadas e que no processo de delegação deve ser considerada a capacidade real e percebida do chefe, assim como de seus subordinados; o fator dominante da decisão da delegação, porém, deve ser a determinação da maneira como se pode conseguir melhor o desempenho total da empresa. 
Gates (1999:392) acredita firmemente que se as empresas atribuírem poder aos seus empregados na solução de problemas e lhes derem ferramentas potentes para isto, elas irão admirar-se com a criatividade e a iniciativa que florescerão destas medidas.

Atribuições das Unidades Administrativas. Segundo Oliveira (2000:161), que denomina as unidades administrativas como unidades organizacionais, elas representam uma forma de consolidar e representar formalmente todas as responsabilidades da unidade considerada. As atribuições das unidades organizacionais da empresa têm como base a especialização do trabalho.

Sistema de Comunicação. Para Litterer (citado por Vasconcellos, 1986:8), comunicação é o processo através do qual uma mensagem é transmitida de um ponto chamado emissor para outro chamado receptor, através de um determinado canal.

Conforme Simeray (1974:49), o funcionamento de uma empresa requer trocas e informações freqüentes e de diversos tipos entre os órgãos que a constituem. Uma ligação estrutural entre dois órgãos é estabelecida basicamente pela comunicação de uma informação.

Segundo Pinto (2002:57), para o sistema de comunicação devem ser definidos os meios e os tipos de comunicação.

Meios de Comunicação: Para Maximiano (citado por Pinto, 2002:61) os meios de comunicação se classificam em três categorias: comunicação pessoal, comunicação escrita e impressa e comunicação por meio de equipamento. A escolha dos meios deve se pautar pela velocidade de resposta e pela possibilidade de registrar e recuperar a informação.

Oliveira (2000:95) afirma existirem dois tipos diferentes de formação de esquemas de comunicação numa empresa:

$>$ O formal, que é conscientemente planejado, facilitado e controlado. Ele segue a corrente de comando em uma escala hierárquica; e 
O informal, que surge espontaneamente na empresa, em reação às necessidades de seus membros.

Tipos de Comunicação: Segundo Maximiano (citado por Pinto 2002:284) os tipos de comunicação referem-se à direção em que se dá a comunicação: para baixo, para cima, ou lateralmente.

Para Oliveira (2000:96), cujas afirmações convergem com as de Maximiano, as comunicações na empresa podem ser:

Horizontal, realizado entre as unidades organizacionais diferentes, mas do mesmo nível hierárquico;

Diagonal ou transversal, realizado entre unidades organizacionais e níveis diferentes; e

Vertical, realizado entre níveis diferentes, mas de mesma área de atuação.

Para Vasconcellos (1986:27), em ambientes dinâmicos o processo de comunicação vertical pode levar a organização ao fracasso porque:

A freqüência com que estas comunicações são necessárias é muito maior, levando a uma sobrecarga da Alta Administração, que se transformará em uma rede de canais de comunicações;

> Quanto maior a organização, maior o número de níveis através dos quais a comunicação passará, aumentando o nível de distorção da mesma;

> Quanto maior a organização, maior o tempo gasto para que a comunicação seja completada.

As principais vantagens de melhores comunicações para os projetos organizacionais, conforme Gerstein (1993:17) são:

Funcionamento organizacional independente do tempo e distância; 
> Maior disseminação da informação e do conhecimento, particularmente às pessoas localizadas em áreas remotas;

$>$ Criação de grupos e organizações ligados eletronicamente;

> Melhoria da comunicação, em proximidade física e distância.

A preocupação com a comunicação e o processamento das informações também foi alvo de um estudo feito por Galbraith (1977:49). Para o autor a capacidade de uma organização em utilizar com sucesso a coordenação do estabelecimento dos objetivos, hierarquia e regras depende da combinação de freqüência de exceções e da capacidade da hierarquia em lidar com elas. Afirma ainda que para o desenho de uma estrutura organizacional pode-se optar por duas formas, ou ambas combinadas:

Reduzir a necessidade de processamento de informação; Aumentar a capacidade de processar informação.

\subsection{CONDICIONANTES DA ESTRUTURA ORGANIZACIONAL}

Vasconcellos (1972:2) propõe um modelo no qual o conjunto de variáveis condicionantes da estrutura organizacional é composto por um fator tecnológico, um fator ecológico, os objetivos organizacionais, o fator estrutura e o fator humano.

Segundo Oliveira (2000:100) os vários fatores que condicionam o estabelecimento de uma estrutura organizacional são: fator humano, fator ambiente externo, fator sistema de objetivos e estratégias e fator tecnologia.

Grau de diversificação de produtos e clientes, ênfase nos planos e objetivos e alocação de recursos são os fatores que influenciam a estrutura para Maximiano (1986:171). 
Pinto (2002:46), baseado em diversos autores, afirma que estes fatores recebem a denominação de fatores condicionantes do processo de organizar e são quatro: meio ambiente, estratégia, tecnologia e recursos humanos.

Já Robbins (2002:418) cita as principais forças identificadas como causas ou determinantes de uma estrutura organizacional a estratégia, o tamanho da organização, a tecnologia e o ambiente.

Os diversos autores pesquisados divergem em alguns pontos mas predominantemente foram citados pela esmagadora maioria dos trabalhos os seguintes condicionantes da estrutura organizacional:

\subsubsection{Fator Humano}

De acordo com Vasconcellos (1986:93), o fator humano deve ser entendido como as características dos indivíduos e grupos que formam a organização, assim como o clima organizacional existente.

Vasconcellos (1972:94), ressalta ser fundamental para o alcance dos objetivos da organização, a existência de compatibilidade entre a estrutura administrativa e o tipo de pessoas que a compõe. O fato do indivíduo não ficar isolado, mas sim fazer parte de um ou mais grupos dentro da organização, sugere a abordagem ao problema sob dois ângulos: características individuais e características do grupo.

Para Oliveira (2000:100), todo executivo deve trabalhar com e por meio de pessoas. E estas pessoas realizam os trabalhos que permitem que os objetivos sejam alcançados. A eficiência da estrutura depende de sua qualidade intrínseca e do valor e da integração dos homens que ela organiza. Portanto, no desenvolvimento de uma estrutura organizacional eficiente deve-se levar em consideração o comportamento e o conhecimento das pessoas que terão de desempenhar as funções que Ihes serão atribuídas. 


\subsubsection{Fator Tecnológico}

Vasconcellos (1972:107) afirma ser a tecnologia um fator fundamental na composição da estrutura administrativa. Ela influencia o tipo de elemento humano que forma a organização, a interação social que ele tem, as tarefas que são executadas, a taxa de mudanças na organização, etc...

Harvey (citado por Vasconcellos, 1972:107) define tecnologia organizacional como sendo os mecanismos ou processos através dos quais uma organização elabora seus produtos ou serviços. Kazt e Rosenzweig (citados em Vasconcellos, 1972:107) por sua vez definem tecnologia como o conjunto de conhecimentos sobre o desempenho de certa tarefa ou atividade. A partir destas definições Vasconcellos formula um conceito para tecnologia organizacional como um conjunto de conhecimentos sobre o desempenho das atividades que levam a organização para seus objetivos.

\subsubsection{Fator Objetivos/Estratégia}

Para Vasconcellos (1972:25) os objetivos da organização e a forma como estes objetivos são atingidos, constituem um importante fator de influência para o desenho da estrutura administrativa. Por objetivo da organização entende-se não apenas um objetivo, mas sim um conjunto de metas globais (lucro, crescimento, filosofia para com o público, ...), numa hierarquia de prioridades.

Oliveira (2000:101) cita que o fator objetivos e estratégias tem influência na estrutura organizacional à medida que, quando os objetivos e estratégias estão bem definidos e claros, é mais fácil organizar, pois se sabe o que esperar de cada membro do grupo que compõe a empresa.

\subsubsection{Fator Ecológico (Ambiente)}

Chiavenatto (1999:599) afirma ser ambiente tudo aquilo que envolve externamente uma organização (ou um sistema). É o contexto em que a organização está inserida. Como a organização é um sistema aberto, ela mantém transações e intercâmbio com seu ambiente. Isto faz com que tudo o que ocorre externamente no ambiente passe a influenciar o que ocorre na organização. 
Oliveira (2000:191) afirma que este aspecto não está relacionado apenas a uma estratégia inicial à época do nascimento da empresa, mas também à avaliação contínua das constantes mudanças no ambiente relevante da empresa e o efeito destas em sua estrutura organizacional.

A título de ilustração e resumo do conteúdo descrito nos itens 2.3 e 2.4, é apresentada na Figura 5 a estrutura organizacional, com seus componentes e condicionantes.

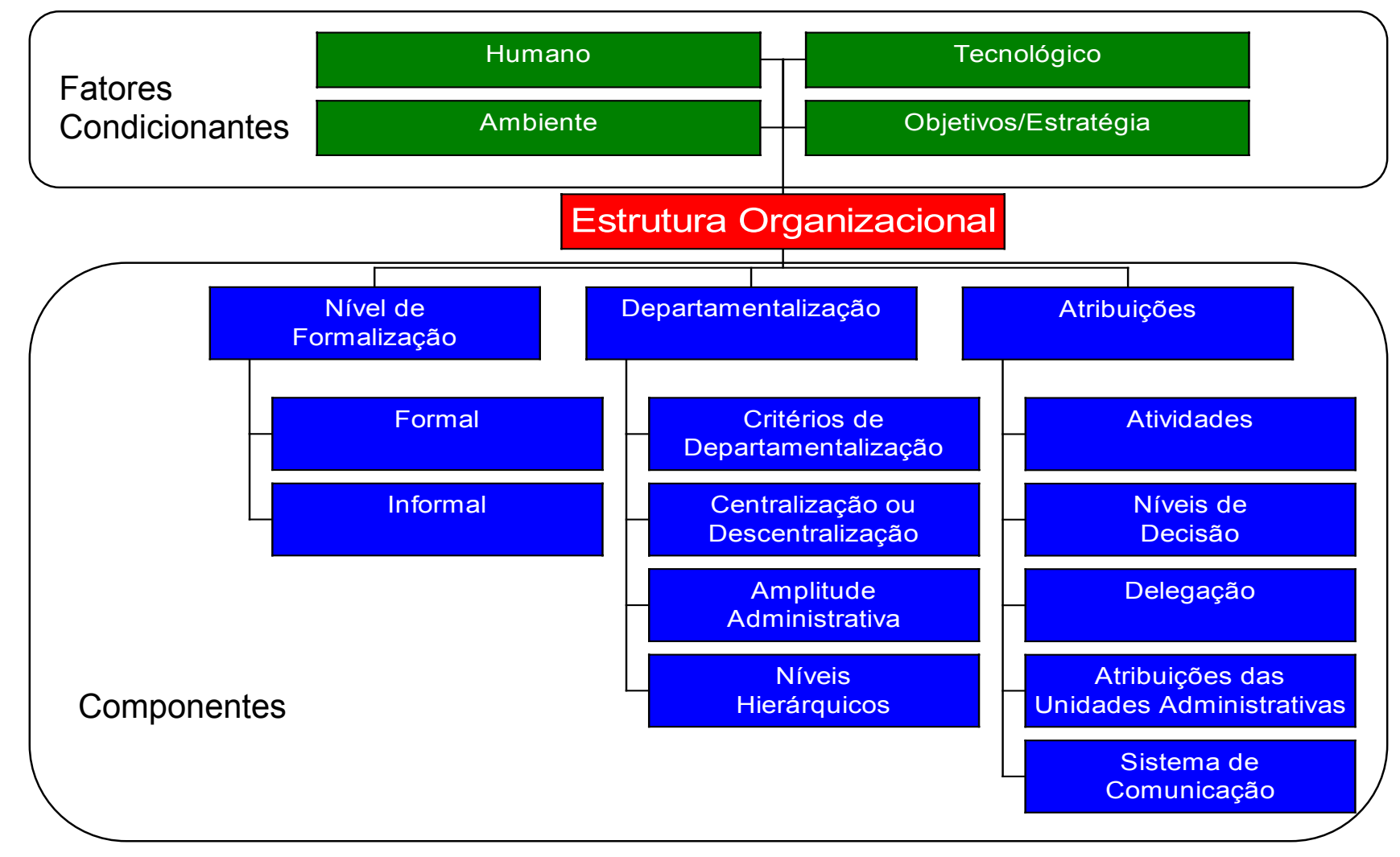

Figura 5. Componentes e Condicionantes da Estrutura Organizacional Fonte : Elaborado pelo autor

\subsection{ABORDAGENS PARA ESTRUTURAS ORGANIZACIONAIS}

Os autores também divergem consideravelmente na definição dos tipos de estruturas organizacionais. Na realidade não se trata especificamente de uma divergência mas formas diferentes de abordar o mesmo tema. 
A estrutura deve ser moldada para tornar-se um meio facilitador da consecução dos objetivos organizacionais. Visto que estes objetivos variam entre organizações, é natural encontrarmos estruturas diferentes. Mas principalmente, mesmo entre organizações que compartilham dos mesmos objetivos, a crença de como alcançá-los de maneira mais eficaz pode variar bastante.

Neste tópico apresentaremos as diversas abordagens para estruturas, cunhadas sob os mais diversos pontos de vista por autores nacionais e internacionais, antigos ou novos, tradicionais ou modernos.

Nesta dissertação optou-se por dividir as estruturas organizacionais em três categorias: Tradicionais, Inovativas e Específicas. As estruturas Tradicionais e Inovativas serão tratadas neste capítulo. As estruturas Específicas - aquelas cunhadas para uma determinada aplicação - serão tratadas no capítulo 4, quando serão abordadas somente aquelas voltadas para as organizações do conhecimento.

Primeiramente apresenta-se o modelo desenvolvido por Burns e Stalker que embora pudesse ser dividido e abordado diretamente dentro dos tópicos de Estruturas Tradicionais e Estruturas Inovadoras, preferiu-se, devido à sua importância histórica, descrevê-lo separadamente.

\subsubsection{Estruturas Mecanicistas e Orgânicas: O modelo de Burns e Stalker}

O modelo desenvolvido por Burns e Stalker é citado pela grande maioria dos autores que trata do item Estrutura Organizacional.

Segundo Vasconcellos (1989:21), em um estudo sobre a indústria eletrônica na Escócia, Burns e Stalker (1961) propuseram duas categorias de organizações: mecanicistas e orgânicas. O grau de inovação, crescimento e satisfação das pessoas foi muito maior nas organizações do tipo orgânico quando elas estavam envolvidas com inovação. Por outro lado, as organizações voltadas para a produção em massa e com ambientes estáveis eram mais bem sucedidas quando apresentavam características do tipo mecanicista. 
Robbins (2002:411) descreve um modelo que ele batizou como "burocracia" que seria similar ao mecanicista. A burocracia é caracterizada por tarefas operacionais altamente rotineiras, realizadas através da especialização, regras e regulamentos muito formalizados, tarefas que são agrupadas em departamentos funcionais, autoridade centralizada, pequena amplitude de controle e processo decisório que acompanha a cadeia de comando.

Para Robbins (2002:417), os modelos de Burns e Stalker são dois extremos de estrutura organizacional. O modelo mecanicista geralmente é sinônimo de burocracia, com extensa departamentalização, alta formalização, rede limitada de informações (basicamente comunicação descendente) e pouca participação dos baixos escalões no processo decisório. No outro extremo está o modelo orgânico. Este lembra bastante a organização sem fronteiras. Ele é "achatado", utiliza equipes multifuncionais e multiierárquicas, tem baixa formalização, possui uma ampla rede de informações (utilizando a comunicação lateral e ascendente, além da descendente) e envolve grande participação no processo decisório.

Souza (1982:41) cita que o modelo mecânico tem como características a maior ênfase na especialização, coordenação entre sucessivos níveis hierárquicos por parte de um escalão superior, escala hierárquica no que diz respeito ao controle, autoridade e comunicação, reforçada por um fluxo de informações que caminha dos níveis inferiores para o topo da hierarquia onde a coordenação final é realizada. Seria basicamente hierárquica dentro dos padrões da escola clássica, sendo adequada às organizações tradicionais, inseridas em ambiente estável, com tarefas relativamente rotineiras e definidas, onde o elemento humano, por pressuposto, prefere executar tarefas previamente programadas do que aquelas que exijam maior criatividade.

O padrão orgânico, em contraposição, ajustar-se-ia melhor a empresas inseridas em um ambiente dinâmico, onde as tarefas não podem ser programadas com muita antecedência, exigindo por parte dos dirigentes maior flexibilidade e criatividade no processo de administração da empresa. Assim, a unidade de comando é substituída por uma estrutura reticular de controle, autoridade e 
comunicação. Isto é, a direção da comunicação ao invés de vertical é lateral, consistindo mais de conselhos e consultas do que ordens. $\mathrm{O}$ centro da autoridade não é único e pode estar localizado em qualquer ponto da estrutura, dado que se pressupõe que a autoridade emana não necessariamente da cúpula administrativa exclusivamente, mas sim de quem detém o conhecimento relevante de determinada função. É pressuposto, por outro lado, que as pessoas, neste padrão de estrutura, preferem trabalhar levando em conta o risco e grau de incerteza do ambiente, o que delas exige maior criatividade na execução das funções, dado que estas não são rotineiras. O padrão orgânico, portanto, apresentaria maior flexibilidade, em relação ao mecânico, no processo de tomada de decisões, uma vez que necessitaria estar mais voltado ao ambiente e suas possíveis mudanças.

Galbraith (1977:28) cita que Burns e Stalker realizaram um dos primeiros estudos sobre a natureza das atividades da organização. Ao observar 20 empresas inglesas e escocesas, eles identificaram dois tipos de organizações: mecânica e orgânica. Mais importante, eles deram a entender que ambos eram eficazes. A forma mecânica, o tipo sugerido pelos teóricos clássicos, era eficaz em mercados estáveis enquanto que o orgânico, tipo sugerido pelos teóricos das relações humanas, era eficaz em mercados e tecnologias que mudam rapidamente.

Terra (2001:128) relata ser amplamente aceito o fato de que o modelo estritamente burocrático de organização está se tornando cada vez mais inadequado para enfrentar os desafios atuais impostos às empresas. As empresas burocráticas (ou mecanicistas) são encontradas, em geral, em ambientes relativamente estáveis enquanto que aquelas que estão rompendo com o paradigma burocrático (as empresas orgânicas ou pós-empreendedoras) são, invariavelmente, encontradas nos setores mais dinâmicos e intensivos em conhecimento.

O modelo de Burns e Stalker foi amplamente utilizado por vários autores que, embora apontando eventuais restrições, fizeram dele a base de suas próprias pesquisas. 
Fazendo uma relação com a classificação feita nesta dissertação nos itens seguintes, a estrutura Mecanicista poderia ser enquadrada como uma estrutura Tradicional e a Orgânica como Inovativa.

\subsubsection{Estruturas Tradicionais}

Vasconcellos (1989:6) argumenta que a estrutura de uma organização deve estar em sintonia com a natureza da atividade e seu ambiente. Atividades repetitivas e ambientes estáveis favorecem as chamadas estruturas tradicionais, que possuem as seguintes características:

Alto nível de formalização;

Unidade de comando;

Especialização elevada;

Comunicação vertical;

Utilização de formas tradicionais de departamentalização.

Robbins (2002:410) utiliza o conceito de "estrutura simples" para caracterizar esta abordagem mais primitiva de organização. Possui baixo grau de departamentalização, grande amplitude de controle, autoridade centralizada em uma única pessoa e pouca formalização. A estrutura simples é uma organização "achatada": possui geralmente apenas dois ou três níveis verticais, um grupo pouco ordenado de empregados e um indivíduo que concentra toda a autoridade do processo decisório.

O principal ponto forte da estrutura simples está exatamente na sua simplicidade. Ela é ágil, flexível, de manutenção barata e torna claras as responsabilidades. Seu principal ponto fraco é que dificilmente pode ser adotada senão pelas pequenas empresas. 


\subsubsection{Estruturas Inovativas}

Ao abordar as mudanças ocorridas nas últimas décadas, Vasconcellos (1989:23) mostra que com o aumento da complexidade do ambiente tornou-se necessária, em alguns setores, a existência de organizações inovativas que pudessem responder de forma eficaz a estas mudanças. As características estruturais destas organizações são inversas àquelas apresentadas pelas organizações tradicionais:

\section{Baixo nível de formalização;}

Utilização de formas avançadas de departamentalização;

Multiplicidade de comando;

Diversificação elevada;

Comunicação horizontal e diagonal.

Estrutura Matricial. Uma das formas mais utilizadas de Estrutura Inovativa é a Estrutura Matricial.

De acordo com Vasconcellos (1989:51) quando duas ou mais formas de estrutura são utilizadas simultaneamente sobre os membros de uma organização, a estrutura resultante chama-se matricial. Um aspecto particular da estrutura matricial é a dupla ou múltipla subordinação. Um determinado especialista responde simultaneamente a um gerente funcional e a um gerente de projetos, por exemplo.

A forma matricial apareceu como uma solução devido à inadequação da estrutura funcional para as atividades integradas, isto é, aquelas que para serem realizadas exigem interação entre as áreas funcionais. A Matriz é uma forma de manter as unidades funcionais mantendo relações horizontais entre elas.

Para Maximiano (1986:168), neste modelo ideal, o especialista tem compromissos funcionais em seu departamento e ao mesmo tempo está 
envolvido em um ou mais projetos, ou seja, cada departamento oferece, por meio de seus especialistas, determinada contribuição técnica para a realização dos projetos. Estes especialistas, portanto, ficam numa posição de dupla subordinação: estão subordinados ao gerente de seu departamento e, simultaneamente, ao coordenador do projeto, conforme mostra a figura abaixo.

\section{Gerente de Engenharia}

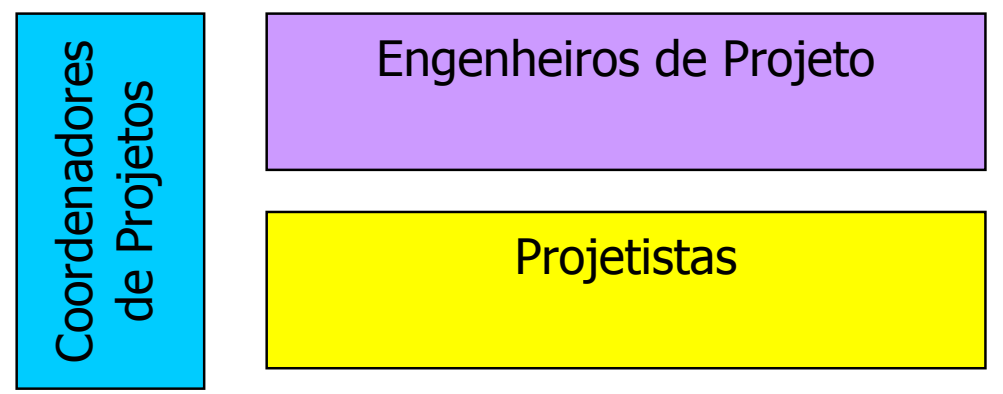

Figura 6. Exemplo de Estrutura Matricial

Fonte : Elaborado pelo autor

A grande vantagem apresentada pela estrutura matricial decorre exatamente do fato de ela combinar dois outros tipos de estrutura. Enquanto a organização funcional favorece a especialização e a acumulação de conhecimentos, a organização por projetos favorece a orientação para algum tipo de resultado ou problema a ser resolvido. A estrutura matricial equilibra estes dois tipos de vantagens, combinando o potencial de ação (estrutura funcional) com a ação propriamente dita, direcionada para o resultado (estrutura por projetos).

Nesta mesma linha, Vasconcellos (1978:6) afirma que a solução de problemas práticos depende cada vez mais da colaboração de um maior número de especializações. A execução de projetos multidisciplinares só pode ser bem sucedida com a necessária adaptação da estrutura administrativa para este tipo de atividade.

Robbins (2002:411) define estrutura matricial como a estrutura que cria uma dupla linha de autoridade; combina a departamentalização funcional com a departamentalização de produtos. A característica mais óbvia da estrutura 
matricial é que ela rompe com o conceito de unidade de comando. Os funcionários destas organizações têm dois chefes - o gerente do departamento funcional e o gerente do departamento de produto. Portanto a estrutura matricial possui uma dupla cadeia de comando.

O principal ponto forte da departamentalização funcional é agrupar especialistas, o que minimiza o número necessário deles, ao mesmo tempo que permite o compartilhamento dos recursos especializados entre os diversos produtos. Seu principal ponto fraco é a dificuldade de coordenação das tarefas dos diversos especialistas funcionais, de modo que as atividades sejam concluídas dentro do orçamento e prazos.

A departamentalização por produtos, por seu lado, oferece exatamente o contrário. Ela facilita a coordenação entre os especialistas para o atendimento dos prazos e limitações orçamentárias. Além disto proporciona uma clara responsabilidade pelas tarefas relacionadas com cada produto, mas com duplicação de atividades e de custos.

A estrutura matricial tenta aproveitar os pontos fortes de cada uma e evitar suas desvantagens. O ponto forte da estrutura matricial está em sua capacidade de facilitar a coordenação quando a organização realiza uma multiplicidade de tarefas complexas e independentes.

Segundo Oliveira Jr. (1999:162) a estrutura matricial é uma boa forma de colocar as pessoas para trocar diferentes experiências, multiplicando as possibilidades de aprendizagem mútua.

Para Chiavenato (1999:679), o desenho matricial permite satisfazer duas necessidades da organização: especialização e coordenação. Por outro lado o autor apresenta algumas limitações. Embora muito utilizada pelas grandes organizações, como meio de trazer a inovação e a flexibilidade, a estrutura em matriz viola a unidade de comando e introduz conflitos inevitáveis de duplicidade de supervisão, enfraquecendo a cadeia de comando e a coordenação lateral. A 
rigor, o desenho matricial impõe uma nova cultura organizacional, uma nova mentalidade e um novo tipo de comportamento à organização. 


\section{CAPÍTULO 3}

Gestão do

\section{Conhecimento}

"O que anda nas cabeças, anda nas bocas." 


\section{CAPÍTULO 3: Gestão do Conhecimento}

\subsection{INTRODUÇÃO}

Na última década, o interesse pelo tema Gestão do Conhecimento cresceu exponencialmente a ponto de colocá-lo em posição de destaque entre os novos títulos bibliográficos de gestão empresarial, entre os novos cursos para administradores - inclusive de nível de pós-graduação - e também dentro das empresas, com a criação de cargos específicos ou de grupos de trabalho para implantação de alguma prática relativa ao assunto.

Por ser um conceito relativamente recente - pode-se ainda afirmar ser um conceito em construção - diversos pontos de vista surgiram e foram apresentados em livros, artigos ou seminários por autores das mais variadas nacionalidades, tendências e formações acadêmicas. O tema já foi tratado na administração, na engenharia de produção, na psicologia, na ciência da computação, na educação. É, sem dúvida, um dos chamados temas transversais.

A própria definição de conhecimento é controversa, apesar dos estudos nesta área terem iniciado há séculos.

O interesse pela Gestão do Conhecimento provavelmente intensificou-se quando a sociedade percebeu que a produção intelectual estava conseguindo gerar mais riqueza, em comparação com a produção industrial. Outro indicador importante foi a constatação que empresas como a Microsoft chegaram a valer vinte vezes mais que seus ativos financeiros. Para Stewart (1998:xvi), os ativos intelectuais sempre tiveram sua importância, embora nunca tanto quanto agora.

Para Nonaka (1997:27), numa economia onde a única certeza é a incerteza, a única fonte garantida de vantagem competitiva é o conhecimento.

Por outro lado a evolução da tecnologia da informação e os novos sistemas de comunicação também podem ser apontados como marcos importantes nesta 
história, pois facilitaram aos gestores e aos especialistas compartilhar e administrar o conhecimento nas organizações.

A Gestão do Conhecimento é uma forma de tornar o ambiente favorável para que a organização identifique suas competências, encontre os conhecimentos que ela já possui, aprenda o que precisa, compartilhe e use estes conhecimentos na velocidade necessária ao desenvolvimento dos seus negócios.

Tipos, formas, características e o ciclo do conhecimento, bem como abordagens para sua gestão em organizações, são alguns dos temas desenvolvidos no presente capítulo.

\subsection{CONHECIMENTO: INTERPRETAÇÕES, CONCEITOS E DEFINIÇÕES}

Depois dos filósofos e estudiosos passarem séculos buscando uma definição de consenso sobre o conhecimento, parece óbvio afirmar-se que este tópico não pretende, em hipótese alguma, exaurir o assunto - nem de perto mas apenas realizar um sobrevôo superficial por diversos autores, de base filosófica ou contemporânea, para ter-se uma idéia da diversidade de interpretações e da vastidão do tema.

\subsubsection{Teoria Filosófica}

Para Hensen (1964:26) no conhecimento encontram-se frente a frente a consciência e o objeto, o sujeito e o objeto. O conhecimento apresenta-se como uma relação entre os dois elementos, que nela permanecem eternamente separados um do outro. $\mathrm{O}$ dualismo sujeito e objeto pertencem à essência do conhecimento. Não no objeto, mas sim no sujeito alguma coisa se altera em resultado da função do conhecimento. O conhecimento pode definir-se como uma determinação do sujeito pelo objeto. $O$ conhecimento diz-se verdadeiro se o seu conteúdo concorda com o objeto designado. 
Segundo Teles (1974:85), o sujeito cognoscente é sujeito apenas enquanto há um objeto que apreender e vice-versa, o objeto é objeto do conhecimento apenas enquanto é apreendido pelo sujeito.

Hensen (1964:21) afirma que a teoria do conhecimento pergunta pela verdade do pensamento, isto é, pela sua concordância com o objeto. Para Teles (1974:82), por outro lado, a teoria do conhecimento vem a ser o estado reflexivo e crítico da origem, da natureza, dos limites e do valor do conhecimento.

Segundo Oliveira (2001:56) a teoria do conhecimento preocupa-se em estudar os problemas fundamentais do conhecimento e pode ser dividida em três áreas:

> Gnosiologia. Preocupa-se em estudar a essência do conhecimento, uma forma de conhecer a realidade, as origens ou fontes do conhecimento, as formas ou espécies da qual se veste o conhecimento, a validade do conhecimento em geral, ou seja, a verdade, e qual o seu critério.

$>$ Epistemologia. Estuda a validade do conhecimento científico, das ciências particulares.

Metodologia. Estuda os meios ou métodos de investigação do pensamento correto e do pensamento verdadeiro que visa delimitar um determinado problema, analisar e desenvolver observações, criticá-los e interpretá-los a partir das relações de causa e efeito.

Para o autor (2001:52) do ponto de vista científico - gnosiologia - o conhecimento é o reflexo e a reprodução do objeto na nossa mente. Desta forma, no processo do conhecimento participam os sentidos, a razão e a intuição.

\subsubsection{Teoria Contemporânea}

Davenport e Prusak (1998:6) lembram que os epistemólogos passaram a vida tentando entender o que significa conhecer, para salientar a dificuldade de definição do tema. Entretanto sugerem uma definição funcional de conhecimento: 
Conhecimento é uma mistura fluida de experiência condensada, valores, informação contextual e insight experimentado, a qual proporciona uma estrutura para a avaliação e incorporação de novas experiências e informações.

Senge e outros (1999:487) definem conhecimento como a capacidade para ação eficaz.

Oliveira Jr. (1999:206) entende que o conhecimento da empresa é o resultado de interações específicas que ocorrem entre indivíduos em uma organização e é portanto um ativo socialmente construído.

\subsection{CLASSIFICAÇÃO DO CONHECIMENTO ORGANIZACIONAL}

Manuel Kant (citado por Hensen, 1964:79), fundador do apriorismo, em seu livro Crítica da Razão Pura (1781), indica ter o conhecimento dois tipos de elementos: a priori e a posteriori. A priori seria o conhecimento adquirido absolutamente independente da experiência e de todas a impressões dos sentidos. A posteriori seria o conhecimento que só pode ser adquirido por meio da experiência, o conhecimento empírico.

Lakatos \& Marconi (2000:16) apontam a existência de dois tipos de conhecimento: o popular e o científico. Para as autoras o que os diferencia é a forma, o modo ou o método e os instrumentos do "conhecer".

Trujillo (citado por Lakatos \& Marconi, 2000:18), por sua vez, registra a existência de quatro tipos de conhecimento: o popular, o científico, o filosófico e o religioso.

Para Oliveira (2001:70), de acordo com a sua profundidade e aproximação da verdade, pode-se distinguir, cinco graus de conhecimento:

> Empírico: fundamentado apenas na experiência; 
> Científico: exige demonstrações, submete-se à comprovação, ao teste.

$>$ Filosófico: procura conhecer as causas reais dos fenômenos, não as causas próximas como as ciências particulares, mas as causas profundas e remotas de todas as coisas, a origem das coisas e suas respostas.

Vulgar: é um conhecimento superficial, sem nenhuma base científica.

Teológico-Religioso: fundamentado em dogmas e ritos, que são aceitos pela fé, não podem ser provados e sobre os quais não se admite crítica, porque é a única fonte da verdade.

Boisot (citado em Choo, 2003:186) classifica os tipos de conhecimento com base na eventualidade de ele ser codificado ou imediatamente difundido:

Público: é codificado e divulgável.

De senso comum: é disseminado mas muito menos codificado.

Pessoal: idiossincrático, difícil de articular.

Privado: conhecimento que pessoa ou grupo desenvolve e codifica a fim de dar sentido a determinada situação.

Por diversos autores, o conhecimento foi classificado em tácito e explícito. Esta será a classificação adotada neste trabalho por ter sido considerada a mais adequada para o estudo da gestão do conhecimento nas organizações.

\subsubsection{Conhecimento Tácito e Conhecimento Explícito}

Polanyi (citado por Nonaka e Takeuchi, 1997:65), caracteriza o conhecimento tácito como pessoal e específico ao contexto, portanto, difícil de ser 
formulado ou comunicado. Já o conhecimento explícito é transmissível em linguagem formal e sistemática.

Segundo Choo (2003:188 e 365) o conhecimento tácito é o conhecimento implícito usado pelos membros da organização para realizar seu trabalho e dar sentido ao seu mundo. É aprendido durante longos períodos de experiência e de execução de uma tarefa, durante os quais o indivíduo desenvolve uma capacidade para fazer julgamentos intuitivos sobre a realização bem sucedida da atividade. O conhecimento explícito é aquele que pode ser expresso formalmente com a utilização de um sistema de símbolos, podendo ser facilmente codificado e difundido. Choo propõe ainda a definição de conhecimento cultural, expresso pelas pressuposições, crenças e normas usadas pelos membros da organização para atribuir valor e significado a novos conhecimentos e informações.

Spender (citado por Nonaka e Takeuchi, 1997:95) classifica o conhecimento tácito em três categorias: consciente, automático e comunal, cada uma com diferentes implicações estratégicas.

Nonaka e Takeuchi (1997:67) apresentam um modelo no qual a criação do conhecimento está amarrada no pressuposto crítico de que o conhecimento humano é criado e expandido através da interação social entre o conhecimento tácito e o conhecimento explícito. Neste modelo são postulados quatro modos diferentes de conversão do conhecimento: Socialização (do conhecimento tácito em tácito), Externalização (do conhecimento tácito em explícito), Combinação (do conhecimento explícito em explícito) e Internalização (do conhecimento explícito em tácito).

Senge (1999:489), em contrapartida, afirma ser importante entender que o conhecimento tácito nunca pode ser reduzido a conhecimento explícito. $\mathrm{Na}$ verdade, falar sobre "conversão de conhecimento tácito em explícito" reflete uma compreensão superficial da própria noção de tácito. Em última análise, contemplar o significado mais profundo do conhecimento tácito leva a reconhecer as sutilezas do que significa "saber" para os humanos. 
Terra e Angeloni (2003c) afirmam não serem os conhecimentos tácito e explícito o mesmo conhecimento em diferentes estágios. $\mathrm{O}$ ato de escrever e tornar o conhecimento de um disponível para outros é, em si mesmo, um ato de aprendizagem e transformação da natureza do conhecimento.

Segundo Moingeon \& Edmondson (1996:29) recursos intangíveis, como o conhecimento organizacional, são fontes de vantagem competitiva pois dificilmente podem ser copiados. Se recursos intangíveis, como o conhecimento tácito, podem ser postos em uso para prover vantagem competitiva, estes recursos são considerados estratégicos e devem ser considerados um capital da empresa.

Para Polanyi (1958:264) os nossos poderes tácitos decidem nossa aderência a uma certa cultura e sustenta nosso desenvolvimento intelectual, artístico, cívico e religioso dentro do seu modelo.

Clemes (2002:142) afirma que, como existem conhecimentos difusos e desorganizados na mente, os quais dificilmente podem ser expressos ao longo de uma cadeia lógica de signos (palavras, frases, discursos), também o conhecimento intuitivo tem caráter tácito. O que ocorre é que a intuição ocupa um nível mais profundo da psique humana: o inconsciente. A intuição é um conhecimento implícito não revelado nem mesmo a seu detentor, o qual não tem acesso deliberado a seu conteúdo.

Segundo Choo (2003:390) a dicotomia entre o tácito e o explícito tem sido enfatizada com tanta freqüência que precisamos nos lembrar não só de que ambos são complementares, mas interdependentes. Numa organização, o exercício de uma forma de conhecimento quase sempre requer a presença e utilização da outra forma. Por trás de cada sistema de conhecimento formal existe uma estrutura de apoio informal igualmente importante e necessária para que a organização possa funcionar bem.

Como exemplo, Gates (1999:188) cita que os custos de treinamento para recepcionistas de hotel - um posto com $100 \%$ de rotatividade anual - caíram de 
11 mil para 3 mil dólares por empregado na empresa Promus. Em vez de gastar duas semanas de treinamento formal dentro de uma sala de aula, os novos recepcionistas passam apenas duas ou três horas em treinamento nos próprios hotéis, aproximando a empresa do seu objetivo de "Desempenho no Primeiro Dia”.

\subsection{CARACTERÍSTICAS DO CONHECIMENTO}

Para administrar o conhecimento empresarial faz-se necessária a identificação antecipada de suas características. Somente de posse do entendimento destas características poderá o gestor definir a estratégia de atuação da organização.

Visando esclarecer melhor o tema, inicia-se contrapondo diversos pontos de vista sobre as definições de termos muitas vezes confundidos entre si, como dado, informação, conhecimento - este último visto em mais profundidade nos tópicos 3.2 e 3.3 - e competência.

\subsubsection{Dado x Informação x Conhecimento x Competência}

A vontade de diferenciar estas grandezas foi, e ainda é, alvo de intermináveis capítulos de diversos autores. O consenso está ainda longe de ser alcançado. O presente item não tem a pretensão de exaurir o tema, nem dar uma definição definitiva para cada um dos conceitos, mas apresentar os pensamentos de uma seleção de autores.

Para Davenport e Prusak (1998:2) dados são um conjunto de fatos distintos e objetivos, relativos a eventos. Num contexto organizacional, dados são utilitariamente descritos como registros estruturados de transações. Organizações modernas normalmente armazenam dados em algum tipo de sistema tecnológico. Até recentemente, eles eram administrados por centros de processamento de dados, os CPDs, que atendiam solicitações de dados feitas pela diretoria e por outros departamentos da empresa. A tendência atual é a relativa descentralização dos dados e sua disponibilidade a partir de pedidos oriundos de computadores pessoais. 
Dados não têm significado inerente. Dados descrevem apenas parte do que aconteceu; não fornecem julgamento nem interpretação e nem qualquer base sustentável para tomada de decisão. Porém, os dados são importantes para as organizações - em grande medida, certamente, porque são matéria-prima essencial para a criação da informação.

Davenport e Prusak (1998:4) descrevem informação como uma mensagem, geralmente na forma de um documento ou uma comunicação audível ou visível. Como acontece com qualquer mensagem, ela tem um emitente e um receptor. A informação tem por finalidade mudar o modo como o destinatário vê algo, exercer algum impacto sobre seu julgamento e comportamento. $O$ significado original da palavra "informar" é "dar forma a", sendo que a informação visa a modelar a pessoa que recebe no sentido de fazer alguma diferença em sua perspectiva. Diferentemente do dado, a informação tem significado.

Para Senge e outros (1999:487), informações são dados com relevância à situação do receptor. Os autores afirmam que grande parte da confusão e desapontamento atuais, em relação à gestão do conhecimento, por exemplo, vem da falta de clareza na distinção entre informação e conhecimento. As pessoas investem em sistemas para captar, organizar e disseminar informações, e depois chamam isto de "conhecimento". Como citado anteriormente, estes autores definem conhecimento como, simplesmente, a capacidade para ação eficaz.

Sveiby (1997:37), de mesma opinião, define conhecimento como uma capacidade para agir.

Para Davenport e Prusak (1998:6) o conhecimento tem origem e é aplicado na mente dos conhecedores. Nas organizações ele costuma estar embutido não só em documentos ou repositórios, mas também em rotinas, processos, práticas e normas organizacionais.

O conhecimento deriva da informação da mesma forma que a informação deriva de dados. Para que a informação se torne conhecimento, os seres humanos precisam fazer virtualmente todo o trabalho. O conhecimento é entregue 
através de meios estruturados, tais como livros e documentos, e de contatos pessoa a pessoa que vão desde conversas até relações de aprendizado. Uma das razões pela qual achamos o conhecimento valioso é que ele está próximo mais do que dados e informações - da ação.

Teixeira (2000:87) distingue "dado" (valor sem significado), "informação" (dado com significado) e "conhecimento" (informação estruturada e contextualizada). Para o autor, o conhecimento é o elemento habilitador da decisão.

Terra e Angeloni (2003c) estudaram diversos autores e consideraram as definições de "informação" bastante similares, no sentido de que a "informação" incluiria a participação humana na propositada organização de dados. Já a definição de "conhecimento" constituiu-se em uma tarefa bem mais complexa. A pesquisa de diversos escritores permitiu aos autores citados entender que "conhecimento" somente pode residir na mente de um indivíduo e é o resultado das experiências e das reflexões humanas baseadas em um conjunto de crenças que são, ao mesmo tempo, individuais e coletivas.

A próxima dimensão, a competência, é definida por Le Boterf (1995:18) como um saber-fazer operacional validado. Descrever a competência não pode se limitar a estabelecer uma lista de conhecimentos ou de saber-fazer, nem mesmo a constatar sua aplicação. A competência pode ser comparada a um ato de enunciar que não pode ser cumprido sem referência ao sujeito que o emite, nem ao contexto no qual ela se situa.

Por outro lado, para Hamel \& Prahalad (1995:233) uma competência é um conjunto de habilidades, aptidões e tecnologias, e não uma única habilidade ou tecnologia isolada. Um fator chave de sucesso reside na integração destas habilidades. Uma competência específica de uma organização representa a soma do aprendizado de todos os conjuntos de habilidades. Portanto, é muito pouco provável que uma competência essencial se baseie inteiramente em um indivíduo ou uma pequena equipe. Para ser considerada uma competência específica da 
organização, uma habilidade precisa passar em três testes: valor percebido pelo cliente, diferenciação entre concorrentes e capacidade de expansão.

Uma competência essencial é uma fonte de vantagem competitiva, pois é competitivamente única e contribui para o valor percebido pelo cliente ou para o custo. Entretanto, nem todas as vantagens competitivas são competências essenciais. Uma competência essencial é também, provavelmente, um fator crítico de sucesso. O conceito de competência essencial também pode variar no tempo. O que é uma competência essencial hoje, pode não ser mais amanhã.

Leonard-Barton (1995:4), define capacidade essencial como o conjunto de conhecimentos que distingue e proporciona vantagem competitiva. Argumenta (1995:19) ainda que um conjunto de conhecimentos tem quatro dimensões: (1) conhecimento e habilidades do funcionário, (2) sistemas técnicos, (3) sistemas gerenciais; e (4) valores e normas.

\subsubsection{O Ciclo do Conhecimento}

Para entender o ciclo do conhecimento e as suas diversas fases optamos por adaptar o modelo sugerido pela empresa de consultoria Arthur D. Little, conforme mostrado na Figura 7. Este modelo divide o ciclo do conhecimento em quatro grandes fases:

> Geração;

> Captura e Análise;

> Síntese e Arquivo;

> Disseminação e Uso 


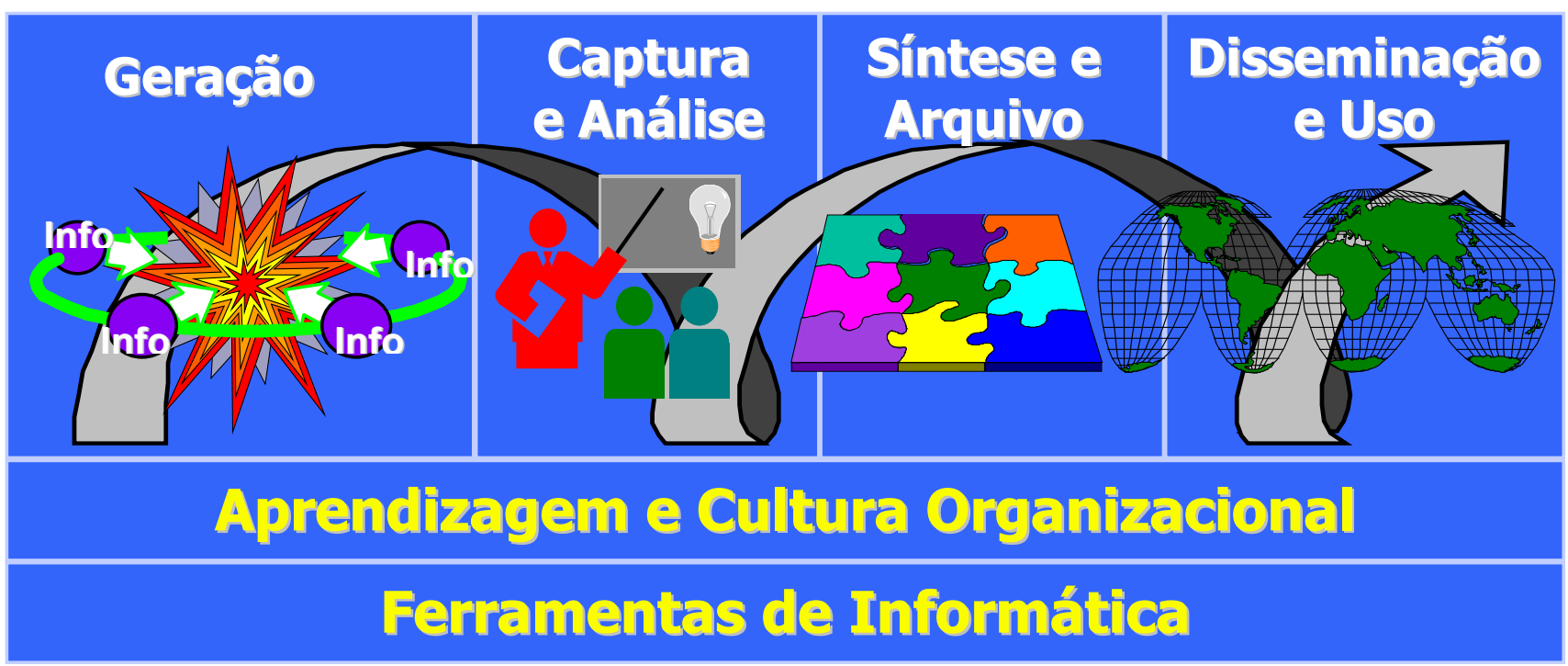

Figura 7. O Ciclo do Conhecimento: Processo

Fonte : Adaptado a partir do modelo de consultoria da Arthur D. Little Inc.

Diversos autores estudaram também este ciclo. Davenport e Prusak (1998:61) citam que o processo de gestão do conhecimento pode ser dividido em 3 fases: geração, codificação e transferência do conhecimento.

Usando a mesma nomenclatura porém partindo de outro foco e com outro objetivo, de ampla abrangência, Choo (2003:51) denominou ciclo do conhecimento à conexão dos três processos de uso estratégico da informação: a criação de significado, a construção do conhecimento e a tomada de decisões.

Kahaner (1996:21), que citou inteligência como um outro termo para conhecimento, apresenta um ciclo de quatro fases: planejamento e direção, captura, análise e disseminação.

A primeira fase, geração, pode ser entendida de maneira abrangente como a forma do conhecimento entrar na organização. Seja através de geração interna ou através de algum outro mecanismo externo. Davenport e Prusak (1998:64) consideraram cinco modos de gerar o conhecimento: aquisição, recursos dedicados (grupos de trabalho), fusão (reunir pessoas com conhecimentos e experiências diferentes), adaptação e redes do conhecimento (incluindo as informais e as auto-organizadas). 
Choo (2003:366) entende que na construção (geração) do conhecimento, a organização identifica e fomenta atividades que criem conhecimentos capazes de fortalecer suas atividades essenciais. Estas atividades criadoras de conhecimento são: resolução compartilhada de problemas, experimentação e prototipagem, implementação e integração de novos processos e ferramentas, e importação do conhecimento.

Na segunda fase, captura e análise, o conhecimento gerado independente da fonte - é internalizado e analisado. A análise consiste basicamente em determinar se aquele conhecimento é útil para a empresa. Ou seja, se ele segue o processo. Uma vez encontrado este conhecimento precisa ser avaliado para verificar sua relevância, utilidade e importância para a organização.

A terceira fase, síntese e arquivo, é a etapa de codificação e coordenação do conhecimento. Segundo Davenport e Prusak (1998:83), o objetivo da codificação é apresentar o conhecimento numa forma que o torne acessível àqueles que precisam dele. Ela literalmente transforma o conhecimento em código para torná-lo inteligível e o mais claro, portátil e organizado possível.

Para definir de que maneira deve-se estruturar um determinado conhecimento é necessário, primeiramente, definir a qual tipo ele pertence: tácito ou explícito, considerando suas variáveis.

Esta etapa contempla também aspectos de segurança da informação e do conhecimento. Tema que cresce em importância a cada dia. Ou seja, formas de arquivar, reter e proteger o conhecimento.

Para Thurow (2001:110) nesta nova era, qualificações e conhecimentos tornaram-se as únicas fontes de vantagem competitiva sustentável a longo prazo. A propriedade intelectual está no centro do sucesso ou do fracasso da empresa moderna. O conhecimento - que costumava vir em terceiro lugar, depois de matéria-prima e capital, na determinação do sucesso econômico - hoje está em 
primeiro. A crescente importância da propriedade intelectual pode ser vista de forma mais direta nos ganhos obtidos com o licenciamento da tecnologia.

O mesmo autor segue afirmando (2001:224) que assim como a revolução industrial começou com um movimento na Inglaterra que aboliu as terras comunais e criou as terras privadas, o mundo precisa agora de um movimento organizado pelos direitos de propriedade intelectual.

Faz parte da terceira fase também o mapeamento do conhecimento e competências. Este é outro dos pilares do modelo conceitual de gestão do conhecimento e será detalhado posteriormente.

A quarta fase, disseminação e uso, também chamada de transferência por alguns autores, é a etapa de transmitir o conhecimento para aqueles que ainda não o possuem e precisam para sua tarefas diárias. Para disseminar um conhecimento específico, assim como na etapa anterior, também é necessário identificar a que tipo ele pertence. $O$ conhecimento mais explícito pode ser melhor codificado e conseqüentemente transferido e disseminado com maior eficácia. Já o conhecimento tácito exige maior contato humano, interação social.

De acordo com Davenport e Prusak (1998:108), a transferência espontânea e não estruturada do conhecimento é vital para o sucesso da empresa. Embora o termo gestão do conhecimento possa supor a transferência formalizada, um dos seus elementos essenciais é o desenvolvimento de estratégias específicas para incentivar estas trocas espontâneas.

Para os autores as conversas que acontecem no bebedouro ou no restaurante da empresa costumam ser ocasiões para a transferência do conhecimento. Influenciados por teorias ultrapassadas sobre a natureza do trabalho, os gerentes por vezes presumem que as conversas são perda de tempo. Embora parte da conversa seja sobre esporte e sobre como anda o tempo, a maioria das conversas em torno do bebedouro é sobre trabalho: as pessoas se perguntam sobre os projetos em curso, trocam idéias e pedem conselho sobre como resolver problemas. 
O modelo descrito nos parágrafos anteriores prevê o apoio de ferramentas e informática ao longo de todo o processo, bem como enfatiza que a diretriz é dada pela cultura organizacional e pela capacidade de aprendizagem da empresa.

\subsection{GESTÃO DO CONHECIMENTO}

A definição de Gestão do Conhecimento ainda gera controvérsias entre os autores. Alguns, no afã de dar a devida importância ao tema, colocam a gestão do conhecimento quase como um sinônimo da própria ciência da Administração:

Bukowitz e Williams (2002:17) definem gestão do conhecimento como sendo o processo pelo qual a organização gera riqueza, a partir do seu conhecimento ou capital intelectual.

Por sua vez, Teixeira (1999:11), com um posicionamento mais pragmático, define gestão do conhecimento como uma certa forma de olhar a organização em busca de pontos dos processos de negócio em que o conhecimento possa ser usado como vantagem competitiva. Conhecimento útil, oriundo da experiência, da análise, da pesquisa, do estudo, da inovação, da criatividade. Conhecimento sobre mercado, concorrência, clientes, processos do negócio, tecnologia e tudo mais que possa trazer vantagem competitiva para a organização.

Para Rossato e Cavalcanti (2001:6), gestão do conhecimento é um processo estratégico que visa gerir o capital intangível da empresa e estimular a conversão do conhecimento. Sendo assim, é muito mais abrangente que a simples implantação de um modelo e a aplicação de uma metodologia.

Oliveira Jr (1999:130) entende por administração do conhecimento o processo de identificar, desenvolver, disseminar, atualizar e proteger o conhecimento estrategicamente relevante para a empresa, seja a partir de esforços internos à organização, seja a partir de processos que extrapolam suas fronteiras. 
O processo de gestão do conhecimento, por ser complexo e dinâmico, torna necessária a utilização de uma metodologia estratégica de gestão do conhecimento que estabeleça um conjunto de etapas a serem cumpridas, facilitando, direcionando, acompanhando e otimizando todo o processo de modo que seus elementos fundamentais sejam implantados com sucesso (Rossato e Cavalcanti, 2001:4).

A gestão do conhecimento compreende, entre tantas variantes, a busca pela resposta de algumas questões, como por exemplo:

O que a empresa sabe?

Como achar um conhecimento na organização?

Como não "reinventar a roda"?

Quais conhecimentos são vantagens competitivas?

Qual conhecimento vale a pena ser gerenciado?

Como gerenciar os diversos tipos de conhecimento? Explícito (patentes) ou tácito (gestão de recursos humanos, manutenção de talentos).

Como compartilhar, transferir, disseminar?

O que precisamos saber?

Como aprender o que ainda não sabemos e precisamos?

Como aprender com os erros e não repeti-los?

Como utilizar o que se sabe para ser mais competitivo?

Como agir rapidamente na solução de problemas?

Como disseminar as melhores práticas? 
Estas perguntas relacionam-se com o entendimento das diversas fases do ciclo do conhecimento e dos seus condicionantes e direcionadores: ferramentas de informática, aprendizagem e cultura organizacional.

Para efeito deste trabalho entende-se gestão do conhecimento pelo processo de identificar quais conhecimentos são necessários para alavancar as competências essenciais (estratégia); mapear quais destes conhecimentos e competências a organização já dispõe (mapeamento de competências e conhecimentos); aprender os que a organização não sabe e precisa (aprendizagem organizacional); e, monitorar o ambiente (inteligência competitiva).

Nos próximos itens abordam-se as características consideradas fundamentais para o entendimento de gestão do conhecimento conforme descrito no parágrafo acima.

\subsubsection{Mapeamento de Competências e Conhecimentos}

Para Hamel \& Prahalad (1995:235) não é possível prestar atenção a tudo; deve haver alguma noção das atividades que realmente contribuem para a prosperidade da organização a longo prazo. Portanto, o objetivo é concentrar a atenção nas competências localizadas no centro, e não na periferia, do sucesso competitivo a longo prazo. Os autores seguem (1995:261) afirmando que a primeira tarefa na administração de competências essenciais é fazer um levantamento destas competências. Uma empresa não pode administrar ativamente as competências essenciais se os gerentes não compartilharem de uma visão de quais são estas competências.

Para Davenport e Prusak (1998:88), um mapa do conhecimento - seja ele um mapa real, páginas amarelas do conhecimento ou um banco de dados sofisticado - indica o conhecimento, porém não o contém. Trata-se de um guia e não um repositório. O desenvolvimento de um mapa do conhecimento envolve localizar conhecimentos importantes dentro da organização e depois publicar em algum tipo de lista ou quadro que mostre onde encontrá-los. Mapas do conhecimento apontam tipicamente para pessoas e também para documentos e banco de dados. 
A principal finalidade e o mais evidente benefício de um mapa do conhecimento é mostrar para as pessoas de dentro da empresa para onde ir quando necessitarem de conhecimento.

Identificar quais são os conhecimentos, habilidades, experiências e capacidades de cada colaborador. Mapear que pessoas na organização têm conhecimento sobre quais assuntos, processos, produtos, concorrentes, clientes, etc. Esta base de dados pode ser utilizada para o planejamento e alocação de recursos em projetos, para a substituição de pessoal, para a avaliação de desempenho das equipes, para o plano de treinamento. Como benefícios desta postura, a empresa reduz custos de treinamento, recrutamento e seleção, passando a usar as pessoas certas nas posições adequadas, investindo naqueles treinamentos realmente necessários (Teixeira, 2000:75).

Para Krogh e outros (2001:152) à medida que a organização aumenta de tamanho, os custos da procura de conhecimentos para a solução de um problema específico ou para a execução de tarefas repetitivas se tornam cada vez maiores. Um dos principais objetivos da abordagem da gestão do conhecimento é reduzir estes custos. Porém o custo total de pesquisa só será recuperado por meio da utilização do conhecimento na execução de uma tarefa criadora de valor.

Na pesquisa de Oliveira Jr. (1999:207) evidenciou-se o fato do novo conhecimento ser criado na empresa a partir da combinação ou integração de conhecimentos previamente existentes. Naquela pesquisa, as subsidiárias com menor nível de conhecimento prévio foram também aquelas que menos criaram conhecimento novo. O desenvolvimento de conhecimento novo em um tema específico, seja know-how ou informação; tácito ou explícito; individual ou coletivo, é fortemente estimulado pelo conhecimento previamente existente naquele tema específico ou em áreas relacionadas (Cohen e Levinthal, citados em Oliveira Jr., 1999:207).

O conhecimento existente para servir de base para a criação coletiva de conhecimento novo precisa estar suficientemente estruturado e codificado quando possível - ou, pelo menos, mapeado. 
Teixeira (2000:144) cita duas estratégias distintas: codificação e personificação. O cerne da estratégia de codificação é o sistema de informação que permite a reutilização do conhecimento. Já a estratégia de personificação foca os canais de comunicação da empresa que levam às áreas de expertise.

Um dos possíveis projetos na área de mapeamento de competências e conhecimentos seria o de desenvolvimento de uma memória organizacional. Segundo Teixeira (2000:147), este projeto englobaria rever os processos organizacionais, mídias usadas, responsabilidades e tecnologias empregadas, visando registrar de forma acessível o acervo de conhecimentos da organização.

\subsubsection{Aprendizagem Organizacional}

Analisadas as questões sobre o mapeamento de competências e conhecimentos, será concentrado o foco nas pesquisas que descrevem ou explicam os diversos modelos de aprendizagem organizacional.

Senge (1999:37) argumenta que não são raros os casos de confusão entre aprendizagem e treinamento. Aprender significa aumentar sua capacidade através da experiência ganha por seguir uma trilha ou disciplina. A aprendizagem ocorre sempre com o tempo e em contextos da "vida real", e não em salas de aula ou sessões de treinamento. Este tipo de aprendizagem pode ser difícil de controlar, mas gera conhecimento que perdura: maior capacidade de ação eficaz em contextos relevantes para aquele que aprendeu. A chave é ver a aprendizagem como inseparável do trabalho cotidiano. Treinamento, em oposição, é tipicamente episódico e separado do contexto no qual os resultados são produzidos.

Starkey (1997:9) define "organização que aprende" como uma metáfora, cujas raízes estão na visão e na busca de uma estratégia para promover o autodesenvolvimento individual dentro de uma organização em contínua autotransformação. 
Senge (1990:23), por sua vez, argumenta que o significado básico da organização de aprendizagem é uma organização que está continuamente expandindo sua capacidade de criar o futuro.

Segundo Argyris e Schön (1978:20), não existe aprendizagem organizacional sem aprendizagem individual, e aprendizagem individual é uma condição necessária mas insuficiente para o aprendizado organizacional. Senge (1990:135), concorda com eles, afirmando que as organizações só aprendem através de indivíduos que aprendem. $O$ aprendizado individual não garante, mas sem ele não há como ocorrer, o aprendizado organizacional.

Visão similar têm Shaw e Perkins (1993:158). Para estes autores a capacidade de adquirir conhecimentos com a experiência é a essência do aprendizado organizacional.

Segundo Choo (2003:390) existem dois modos complementares de aprendizagem organizacional: a investigação e a exploração. Investigar é aprender por meio da descoberta ou da experimentação, que leva a encontrar novos objetivos e oportunidades não aproveitadas. Explorar é aprender por meio da especialização e do acúmulo de experiências.

Para Terra (1999:36), as abordagens mais tradicionais sobre aprendizado e criatividade nas organizações advêm da psicologia e dos estudos sobre inovação. Ambas, por sua vez, são fundamentais para uma melhor apreensão das teorias sobre "organizações que aprendem" e para embasar teoricamente as práticas da "organizações inovadoras". No campo da pesquisa psicológica, incluem-se as relativas à psicologia experimental, psico-social e ocupacional entre outras. Já a pesquisa sobre inovação tem sido tratada primordialmente por estudiosos da teoria administrativa e, mais específica e originalmente, por pesquisadores ligados à administração de Pesquisa e Desenvolvimento.

Terra (1999:57) destaca algumas características comuns nas organizações de aprendizagem, citadas por diversos autores, como sendo as seguintes: 
Reconhecimento explícito do valor econômico do conhecimento;

Capacidade de desenvolver o know-why, além do know-how;

Capacidade de questionar valores, cultura e mudar o comportamento;

> Estímulo à experimentação e aprendizado através da detecção e correção de erros;

> Habilidade em compartilhar insights, experiências e informações individuais;

Habilidade criadora;

Capacidade em articular conhecimento conceituais sobre uma experiência;

Utilização da capacidade criativa de seus funcionários;

Busca ativa de informações do ambiente onde se inserem;

Sistemas de informação precisos e com formato que facilita o uso.

A aprendizagem é o único recurso infinitamente renovável. Os concorrentes podem ter acesso a outros recursos: capital, mão de obra e até tecnologia e conhecimento. Mas ninguém consegue comprar, copiar ou fazer engenharia reversa com a capacidade de uma empresa em aprender (Senge:1999, 35).

A aprendizagem organizacional, na realidade, é utilizada para suprir uma lacuna de conhecimento existente na empresa.

Segundo Crawford (1994:44) o único caminho para os trabalhadores da sociedade do conhecimento manterem suas habilidades e conhecimentos e atuarem efetivamente como capital humano é se comprometendo com um aprendizado contínuo e vitalício. 
Para Argyris e Schön (1978:29) a aprendizagem organizacional ocorre quando membros da organização atuam como agentes do aprendizado para a organização, respondendo às mudanças por meio de deteç̧ão e correção de erros, embutindo os resultados da sua pesquisa em imagens e mapas compartilhados da organização. Ou seja, quando os membros, reagindo às mudanças do ambiente, detectam e corrigem erros por meio de modificação de estratégias, suposições ou normas.

Os autores promovem alguns conceitos relativos à aprendizagem organizacional. No conceito de aprendizagem de ciclo único o critério de sucesso é a eficiência dentro das normas de desempenho vigentes. Os indivíduos respondem ao erro modificando estratégias e hipóteses, mas mantendo as normas organizacionais constantes. No aprendizado de ciclo duplo, a resposta aos erros detectados passa também pela averiguação das normas organizacionais, bem como resolver as inconsistências e elaborar novas normas mais eficazes. Quando a organização se engaja no aprendizado deutérico (de segunda ordem), seus membros aprendem sobre aprendizagem organizacional e decodificam seus resultados em imagens e mapas. A busca pela aprendizagem organizacional precisa, segundo os autores, tomar a forma do aprendizado deutérico.

Dixon e Ross (1999:504) propõe um ciclo de aprendizagem organizacional, conforme mostrado na Figura 8. 


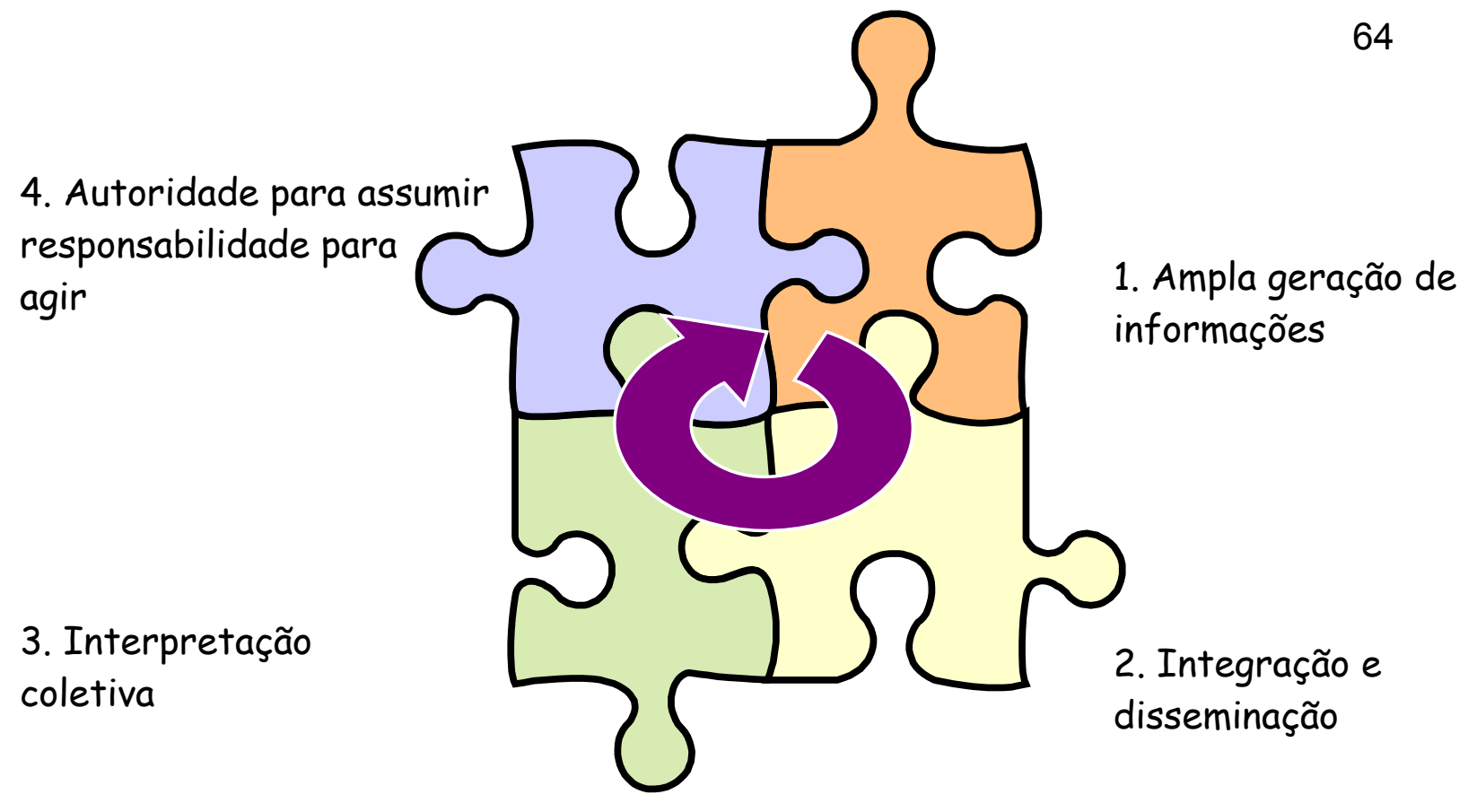

Figura 8. O Ciclo da Aprendizagem Organizacional Fonte : Adaptado de Dixon e Ross (1999:504)

Ampla geração de informações. É o estágio de reunião e criação do conhecimento. Para passar para a próxima fase, os autores entendem que a organização deve configurar sistemas para romper fronteiras, levando as informações através das barreiras organizacionais. Como exemplo são citadas a comunicação transfuncional, banco de dados das melhores práticas, videoconferência, consultoria interna de assistência aos pares, "regentes" do conhecimento.

Integração e disseminação. Cada indivíduo deve entender o seu papel, o papel da sua equipe e de seu trabalho para toda a organização. Nesta etapa é ressaltada pelos autores a importância de se construir pontes, desenvolvendo a estrutura para apoiar o diálogo por todo o sistema organizacional como instrumento para se alcançar a interpretação coletiva.

Interpretação coletiva. Trata-se do entendimento da equipe sobre a organização. Para atingir a próxima fase, os autores sugerem focar na descentralização da tomada de decisão para obter flexibilidade e velocidade, implantando autonomia local, responsabilidades locais por perdas e lucros, participação no sucesso da organização (plano de bônus e compartilhamento de lucros). 


\section{Autoridade para assumir responsabilidade para agir. É,} resumidamente, agir baseado em sua própria experiência. Para prosseguir e resultar em um novo conhecimento deve-se, segundo os autores, organizar a observação, desenvolvendo mecanismos para reunir informações sobre os resultados das ações. Podem ser, por exemplo, medições de resultados, "lições aprendidas", sistemas de informações gerenciais, reuniões de conclusão.

Aprender também faz parte do desenvolvimento de novas competências. Hamel e Prahalad (1995:269) exemplificam que podem ser necessários dez ou mais anos para desenvolver uma liderança mundial em uma área de competência essencial, portanto a consistência de esforços é fundamental. A consistência depende antes de tudo de um profundo consenso em relação às competências que serão desenvolvidas e sustentadas e à estabilidade das equipes de gerência encarregadas do desenvolvimento de competências.

Shaw e Perkins (1993:168) argumentam que cinco elementos são importantes na criação de uma empresa eficiente em aprender:

Limites abertos. Abrir os limites da organização às novas idéias e informação. Isto pode ser feito através de participação em seminários, contratação de pessoas de fora, ouvir constantemente clientes, fornecedores, ...

Motivação para correr riscos. O aprendizado não pode ocorrer sem experimentação. As organizações eficientes criam um ambiente no qual as pessoas se sentem ao mesmo tempo motivadas e capazes de experimentar.

> Experimentos estruturados para o aprendizado. As empresas que aprendem com eficiência reconhecem o valor do fracasso produtivo e as deficiências do sucesso improdutivo.

Ambientes que proporcionam e disseminam o aprendizado. Os que aprendem com eficiência dedicam muito tempo e esforço realizando 
encontros, sessões fora do local de trabalho, conferências e programas de treinamento para disseminar o aprendizado.

Estímulo à capacidade de agir. Um estímulo real ocorre com a aplicação do aprendizado por toda a organização. Isto requer a superação da síndrome do "não foi inventado aqui", que leva à resistência às idéias provenientes de outros lugares. As organizações precisam motivar as pessoas a usarem o que outras aprenderam. Parte disto vem da recompensa às pessoas que aplicam conhecimento dos outros, em oposição à recompensa apenas aos que têm idéias.

Stata (1997:378) afirma que o ritmo em que indivíduos e organizações aprendem pode se tornar a única vantagem competitiva sustentável, especialmente em setores intensivos em conhecimento.

Para Leonard-Barton (1995:261), as características da organização em constante renovação são: 1) entusiasmo pelo conhecimento; 2) guiar-se e estar adiante em conhecimento; 3) acoplamento firme de conjuntos de habilidades complementares; 4) iteração em atividades; 5) aprendizagem de alta ordem; 6) líderes que ouvem e aprendem.

A aprendizagem organizacional é um passo importante na busca da competitividade, cujo principal aliado é o sistema de inteligência competitiva.

\subsubsection{Inteligência Competitiva}

Segundo Kahaner (1996:16), inteligência competitiva é um programa sistemático de coleta e análise de informações sobre atividades e tendências dos negócios dos concorrentes para favorecer os objetivos da empresa.

Para Sammon e outros (1984:91) inteligência é o processo analítico que transforma dados desagregados sobre o competidor em conhecimento relevante, preciso e estrategicamente utilizável acerca da posição, desempenho, capacitações e intenções do concorrente. 
A observação da concorrência, ou a inteligência do concorrente é definida por Fuld (1985:9) como informação atual e altamente específica sobre uma corporação.

Fuld (citado em Teixeira, 2000:87) define inteligência competitiva como sendo o resultado da análise de informações e dados coletados, que irá embasar decisões. O processo de inteligência competitiva é que dá a visão geral consistente, a partir de informações. Três seriam os seus principais componentes: fonte, análise e sistema de inteligência. É diferente de "espionagem", pois são respeitados os aspectos éticos e legais da atividade.

Para Carvalho (1995:104) o sistema de inteligência competitiva é um subsistema do sistema de informação de marketing e tem como usuários os responsáveis pelas decisões de marketing da empresa. Com ele o diretor ou gerente de marketing e seus assessores adquirem conhecimento e desenvolvem sensibilidade acerca de seu ambiente competitivo.

Um exemplo de inteligência competitiva seria a criação de processos e ferramentas que permitam à empresa monitorar melhor seu mercado e a concorrência, com informações de apoio à decisão nos negócios, argumenta Teixeira (2000:148).

Weick (citado em Choo, 2003:363) afirma que a criação de significado é provocada por uma mudança no ambiente que gera descontinuidade no fluxo de experiências em que estão engajadas as pessoas e atividades de uma organização. Estas descontinuidades fornecem dados brutos do ambiente, aos quais será preciso dar significado. A função da criação de significado é interpretar o ambiente por meio de seqüências de interpretação, seleção e retenção.

De acordo com Kahaner (1996:23), inteligência competitiva não é uma função, é um processo. Um programa de inteligência competitiva tem como principais objetivos:

Antecipar as mudanças no mercado e as ações dos competidores; 
Descobrir novos ou potenciais competidores;

Aprender com o sucesso ou falhas dos outros;

Aprender sobre novas tecnologias, produtos e processos que afetam os negócios da empresa;

$>$ Entrar em novos negócios;

Ajudar a implantar as mais recentes ferramentas de gerenciamento.

Segundo Carvalho (1995:108) o sistema de inteligência competitiva, além da grande utilidade para análise e formulação da estratégia e para elaboração e execução do planejamento de marketing, tem pelo menos outros dois benefícios:

> Parâmetros para a formulação e ajustes dos programas de ação mercadológicos e das práticas operacionais de outras áreas da empresa;

Impacto na motivação dos colaboradores, proporcionado pela difusão de informações comparativas do desempenho da empresa com os concorrentes.

Para Sammon e outros (1994:96) se as necessidades de inteligência competitiva não forem primeiro cuidadosamente definidas e ordenadas por importância de acordo com a orientação da alta administração, as prioridades serão estabelecidas pelos que produzem a inteligência ao invés de o serem por quem as usa - os dirigentes que tomam as decisões chave.

Para Krogh e outros (2001:127) um dos principais desafios para os gerentes na economia do conhecimento será descobrir o que as empresas precisam saber no futuro.

Uma das possibilidades para descobrir o que a empresa precisa saber é adotar técnicas de inteligência competitiva. De posse destes dados a empresa pode partir para o desenvolvimento de uma agenda de aquisição de competências. 
Segundo Hamel e Prahalad (1995:264), a agenda de aquisição de competências de uma empresa deve ser determinada pela sua arquitetura estratégica. Uma matriz competência-mercado, como a exemplificada abaixo, pode ser útil para definir a aquisição e as metas de distribuição.

\begin{tabular}{|c|c|c|c|}
\hline \multirow{2}{*}{$\begin{array}{c}\text { Competência } \\
\text { Essencial }\end{array}$} & Nova & $\begin{array}{c}\text { Para criar, proteger e } \\
\text { ampliar a participação } \\
\text { nos mercados atuais }\end{array}$ & $\begin{array}{c}\text { Para participar de } \\
\text { mercados mais } \\
\text { interessantes no } \\
\text { futuro }\end{array}$ \\
\hline & \multirow[t]{3}{*}{ Existente } & $\begin{array}{l}\text { Alavancar melhor as } \\
\text { competências } \\
\text { essenciais atuais }\end{array}$ & $\begin{array}{l}\text { Criar novos produtos } \\
\text { ou serviços } \\
\text { redistribuindo ou } \\
\text { recombinando } \\
\text { competências } \\
\text { essenciais existentes }\end{array}$ \\
\hline & & Existente & Novo \\
\hline & & \multicolumn{2}{|c|}{ Mercado } \\
\hline
\end{tabular}

Figura 9. Definição da Agenda de Competências Essenciais

Fonte : Adaptado de Hamel e Prahalad (1995:264)

\subsection{GESTÃO DO CONHECIMENTO: MODISMO, IDEALISMO OU REALIDADE?}

Sempre que um novo termo aparece no horizonte do administrador, invariavelmente surge a dúvida: será esta inovação gerencial um modismo, idealismo ou realidade? Sendo também uma inovação gerencial, a gestão do conhecimento, muito provavelmente suscitou este questionamento ou discussão na alta cúpula das organizações. Este item visa contribuir para a discussão, apresentando a perspectiva de diversos autores.

Abrahamson (citado por Caldas e Wood, 1999:70) afirma não serem as organizações totalmente independentes para escolher que inovações administrativas devem adotar ou rejeitar: alguns agentes externos e/ou organizações podem ser suficientemente poderosos para impor a adoção ou a rejeição de inovações gerenciais entre as organizações menos poderosas. O 
autor continua explicando que sob condições de incerteza, as organizações tendem a imitar as decisões de adoção de outras.

Prusak (1996:ix), afirma que muitos de nós, fazendo pesquisa neste tema, temos visto a ascensão e queda de muitos destes procedimentos - todos os quais tentando oferecer às empresas uma nova estrada para atingir uma vantagem competitiva sustentável. Entretanto quando muitos destes tiros perdem a força, nós concluímos que, excluindo-se as políticas monopolísticas e outras irregularidades de mercado, não existe nenhuma outra vantagem sustentável senão o que a empresa sabe, como ela pode utilizar o que ela sabe e o quão rápido ela pode aprender algo novo!

Takahashi (2000:5) é taxativo: a Sociedade da Informação não é modismo.

Em seu trabalho, Damiani (2001) oferece uma revisão das mais importantes e recentes contribuições feitas à literatura da gestão do conhecimento e apresenta os resultados da pesquisa sobre gestão do conhecimento, realizada entre 1999 e 2000, que abrangeu as 500 maiores empresas brasileiras segundo a revista Exame e as 500 maiores empresas americanas segundo a revista Fortune. Os resultados refletem a atitude dos administradores frente à gestão do conhecimento, assim como as expectativas e as barreiras que permeiam a implementação desses projetos.

O autor demonstra em sua pesquisa descrita no artigo "Gestão do Conhecimento: Um estudo comparativo Brasil x Estados Unidos" não ser este tema um modismo passageiro pois de acordo com a percepção da grande maioria dos respondentes ( $81 \%$ dos brasileiros e $92 \%$ dos americanos) a Gestão do Conhecimento é importante para o futuro dos negócios.

As conclusões do trabalho de Terra (1999) sugerem que as práticas gerenciais que foram relacionadas a uma efetiva Gestão do Conhecimento e, conseqüentemente, ao estímulo ao aprendizado, à criatividade e à inovação no contexto organizacional, estão fortemente associadas a melhores desempenhos empresariais. 
Davenport e Prusak (1998:196), argumentam ainda que gestão do conhecimento não é algo totalmente novo. Ela baseia-se em recursos existentes, com os quais a organização já está contando - uma boa gestão de sistemas de informação, uma gestão de mudança organizacional e boas práticas de recursos humanos.

Teixeira (2000:12) concorda com Davenport e Prusak: "Gestão do Conhecimento não é novidade. É um novo nome para uma preocupação antiga".

Ao que parece, a Gestão do Conhecimento é uma forma necessária de abordar a Administração de Empresas na era do conhecimento. Como citado por diversos autores, não é nada novo mas intensificou-se a preocupação pelo ser humano e pelo que ele sabe, já que nesta nova sociedade valoriza-se o conhecimento. É uma realidade pois diversos estudos, conforme citado nos parágrafos anteriores, mostraram que neste novo contexto as empresas administradas sob uma ótica mais focada em aprendizagem e inovação tendem a ter mais sucesso que as demais. 


\section{CAPÍtULO 4}

\section{A Estrutura}

\section{Organizacional}

\section{Como Elemento}

Facilitador da Gestão do

Conhecimento

"O modo como você reúne, administra e usa a informação determina se vencerá ou perderá."

Bill Gates 


\section{CAPÍTULO 4: A Estrutura Organizacional Como Elemento Facilitador da Gestão do Conhecimento}

\subsection{INTRODUÇÃO}

Drucker (1995:28) afirma ser função das organizações tornar produtivos os conhecimentos. Os conhecimentos por si mesmos são estéreis. Eles somente se tornam produtivos se forem soldados em um só conhecimento unificado. Tornar isto possível é a tarefa da organização, a razão para a sua existência, a sua função.

Segundo Kogut e Zander (citados em Oliveira Jr., 1999:22), as empresas são meios eficientes pelos quais o conhecimento é criado e transferido. A empresa é entendida então como um estoque de conhecimento que consiste basicamente em como a informação é codificada e disponibilizada para aplicação, assim como no conhecimento relacionado à coordenação das ações da organização. O que vai determinar o sucesso da empresa é a sua eficiência neste processo de transformação de conhecimento existente no plano das idéias para conhecimento aplicado no plano das ações, em comparação com a eficiência de outras empresas. Cabe à organização, portanto, atuar como agente organizador do conhecimento existente, tornando-o aplicável e gerando novo conhecimento.

Para Nadler (1993:236) Projeto Organizacional e Aprendizagem Organizacional são - ao lado de Estratégia e Qualidade - os fatores críticos para o sucesso na competitividade. Isto reforça a importância dos temas, principalmente se tratados em conjunto.

Mohrman (citado por Myers, 1996:3) afirma que um desenho organizacional apropriado habilita a organização a executar melhor, aprender mais rápido e mudar mais facilmente. 
Nosso propósito neste capítulo é entender os aspectos de relacionamento entre os dois temas principais da dissertação: Estrutura Organizacional e Gestão do Conhecimento. Os tópicos a serem apresentados exercem grande influência em ambos.

A análise envolverá a abordagem de agentes facilitadores e eventuais obstáculos à gestão do conhecimento dentro das empresas que atuam no cenário contemporâneo.

\subsection{CULTURA ORGANIZACIONAL}

Segundo Srour (1998:xx), nos últimos tempos as relações de trabalho passaram por radicais mudanças: os trabalhadores deixaram de ser descartáveis e desqualificados (meras engrenagens das linhas de produção) para tornarem-se trabalhadores qualificados e polivalentes (profissionais organizados em ilhas de trabalho).

Na realidade o autor pretende a conscientização de que o modelo taylorista-fordista da gestão dos processos de trabalho, fragmentado em tarefas repetitivas e simplificadas, perdeu vigência. Isto aconteceu na medida em que, no seio das organizações, ao operário padrão clássico indistinto em seu macacão sujo, oprimido e discriminado se contrapôs um novo tipo de profissional, escolarizado e capacitado, portador de qualificações técnicas sujeitas à permanente reciclagem.

As organizações são a expressão de uma realidade cultural, e essa realidade cultural reflete os valores, as crenças, as idéias, os sentimentos e as vontades da comunidade institucional.

Segundo Schein (1985:9 e 1987:262) cultura significa um modelo de suposições básicas que um dado grupo inventou, descobriu ou desenvolveu em aprendizagem para enfrentar seus problemas de adaptação externa e integração interna, e que trabalhou bem o suficiente para ser considerado válido e, por isto, para ser dito para novos membros como a maneira correta de perceber, pensar e sentir em relação a estes problemas. 
Para Robbins (2002:503) a cultura cumpre varias funções no seio de uma organização:

> Cumpre a função de definir os limites; ou seja, os comportamentos que diferenciam uns de outros;

> Transmite um sentido de identidade a seus membros;

$>$ Facilita a criação de um comprometimento pessoal com algo mais amplo que os interesses egoístas do indivíduo;

D Estimula a estabilidade do sistema social.

A cultura é o vínculo social que ajuda a manter a organização unida ao proporcionar normas adequadas do que devem fazer e dizer os empregados.

Para Schein (1985:44) cultura é um termo largamente utilizado como explicação para muitas coisas que acontecem na organização. O que nem sempre é verdadeiro.

A abrangência da cultura organizacional é mais ampla do que se pode supor. A cultura organizacional exprime a identidade da organização, resultante de um sistema de significações que atua como elo de ligação de todos os membros, em torno de objetivos comuns.

Nos processos de transformação organizacional, não devem ser esquecidos os elementos da cultura organizacional. Ignorá-los é ignorar como é importante e estratégico o fato de que: se não existir uma visão compartilhada, nunca se poderão gerar energia e significados suficientes para mobilizar a organização e seus recursos humanos no processo de mudança.

Uma das maneiras de se conhecer ou inferir sobre a cultura de uma organização é estudando a sua estrutura, seus sistemas de informação e controle, sua missão, objetivos e história. 
Schein (1985:121) esclarece, entretanto, que o problema de se inferir a cultura através da estrutura existente é que não se pode decifrar quais suposições implícitas iniciais conduziram a esta estrutura. A mesma estrutura pode ser resultante de diferentes suposições implícitas.

Por exemplo, no caso de uma organização muito centralizada, pode-se inferir que seus líderes consideraram não ser possível confiar nas pessoas ou que a estrutura é assim por uma tradição histórica. Ou seja, duas organizações com a mesma estrutura podem não ter culturas similares. A estrutura pode ser uma das variáveis no estudo da cultura, assim como a cultura também exerce influência na estrutura mas não é seu único determinante.

Segundo Schein (1985:183) cultura foi definida como o resultado da aprendizagem em grupo. Quando pessoas se deparam com um problema simultaneamente, e têm que achar a solução juntos, tem-se a situação básica da formação da cultura.

Atualmente é necessário que as organizações desenhem estruturas mais flexíveis à mudança, e que esta mudança se produza como conseqüência da aprendizagem de seus membros.

Para Choo (2003:150) a existência de crenças e comportamentos consensualmente aceitos pelo grupo é a essência da cultura.

Pessoas podem ter comportamentos diversos em relação aos mais variados temas. Um dos comportamentos mais interessantes para o presente estudo é o comportamento informacional que, segundo Davenport (2000:110), se refere ao modo como os indivíduos lidam com a informação. Há três espécies fundamentais de comportamentos ligados à informação que melhoram o ambiente informacional de uma empresa:

> Compartilhamento de informações, a ser tratado no item 4.4;

Administração de sobrecarga de informações, e; 
Redução de significados múltiplos.

Os resultados de pesquisas até agora empreendidas sobre a prática das empresas mostram que alguns fatores podem facilitar ou dificultar a implantação de processos de gestão do conhecimento. Davenport e Prusak (1998:191) apontam a necessidade de se ter uma estrutura técnica e organizacional adequada - utilização de programas de computador como Lotus Notes e a Internet, por exemplo, uma estrutura de conhecimento padrão flexível (equilíbrio entre a necessidade de flexibilidade - porque o conhecimento muda - e a padronização, para que possa ser utilizado por diversas pessoas) e múltiplos canais para transferência do conhecimento. Ressaltam, ainda, a necessidade de se ligar ao desempenho econômico ou valor da indústria (quanto se ganha ou se economiza com o projeto). Mas argumentam ser necessário desenvolver, além de uma cultura amigável ao conhecimento (pessoas com orientação positiva em relação ao conhecimento, que queriam compartilhar conhecimento e que os projetos sejam adequados à cultura), políticas e práticas que possam motivar as pessoas a participar efetivamente do programa.

Nesta perspectiva, Terra (2001:114) destaca entre as dimensões da prática gerencial a serem adotadas pelas organizações na gestão do conhecimento, os aspectos da cultura organizacional. Segundo o autor uma das preocupações da alta administração deve ser o desenvolvimento de uma cultura organizacional voltada à inovação, à experimentação, ao aprendizado contínuo e comprometida com resultados de longo prazo.

Na Quinta Disciplina, Senge (1990) busca identificar um aporte pessoal e grupal que pode interferir na maneira como as organizações aprendem. $\mathrm{O}$ princípio é de idéias-guia que mantêm uma coesão no grupo, contaminando as pessoas, sem este direcionamento do propósito perde-se a capacidade dos grupos apoiarem as mudanças necessárias. Na verdade as idéias-guia são apoiadas pelas mudanças nas atitudes e crenças dos indivíduos. A visão de Senge baseia-se nos estudos de Argirys que apontam que mudanças pessoais profundas só ocorrem quando de fato as pessoas se perguntam "o que me levou a fazer isto ?". Parece haver uma clara relação de tempo entre a mudança das 
pessoas facilitando a mudança e instalação de uma gestão de conhecimento que, ao mesmo tempo que é criada, apóia a mudança dos indivíduos.

Do ponto de vista geral, pode-se dizer que as organizações comprometidas com o sucesso estão abertas a uma constante aprendizagem. Isto implica gerar condições para manter uma aprendizagem contínua e considerá-la como o ativo fundamental da organização.

Segundo Oliveira Jr. (2001:135), desde que a organização esteja empenhada em criar, transferir, disseminar e aplicar o conhecimento terá que se adaptar uma nova formatação. Para isto, necessita codificar e simplificar o conhecimento dos indivíduos e dos grupos e torná-los acessível a todos. Para o autor em um nível mais básico, "o processo de estabelecimento de uma linguagem comum é a forma desenvolvida e adotada por indivíduos e grupos nas empresas para expressar e articular crenças comuns, conectando crenças de indivíduos e criando uma estrutura para o conhecimento organizacional". Desta forma, a comunicação torna-se um processo fundamental para a transformação cultural em busca da gestão do conhecimento organizacional.

Diante desta necessidade de transformação ou mudança cultural, Schein (1999:394) destaca que o grande erro na mudança cultural está centrado na idéia de criar uma nova cultura. Para o autor, não há como criar uma nova cultura, pode-se sim estudá-la em sua profundidade, buscando compreendê-la para então propor valores, idéias e modos diferentes dos utilizados. Desta forma, prepara-se a organização para a evolução cultural, que dependerá da aceitação e da adoção dos novos comportamentos provenientes dos valores estabelecidos na transformação. Salienta ainda que este processo é demorado e incerto, requerendo um trabalho longo, incremental e fascinante.

Por outro lado, dada a própria natureza do conhecimento, criado a partir da interação, da ação, do momento e da troca, fica clara a importância das pessoas, do papel que desempenham e da sua percepção em relação ao processo como um todo. 


\subsection{GERAÇÃO DE CONHECIMENTO E CRIATIVIDADE}

Para Thurow (2001:100), qualquer sociedade que valoriza a ordem acima de tudo não será criativa, mas sem o correto grau de ordem a criatividade desaparece como se caísse em um buraco negro. Uma grande criatividade requer fatos, muita imaginação e saltos ilógicos para adiante, cuja correção é provada trabalhando-se de trás para diante até que se chegue a princípios conhecidos.

Mas a geração não depende só da criatividade e da curiosidade dos recursos humanos empresariais. Ela depende também dos investimentos em pesquisa e desenvolvimento.

A quantia a investir não é óbvia. Nas quatro maiores economias do mundo, os gastos com pesquisa e desenvolvimento em relação ao produto interno bruto são semelhantes: França e Alemanha, 2.3\%; Japão, 2.8\% e Estados Unidos, $2.5 \%$. Entre as empresas privadas as diferenças de gastos são grandes: Boeing, 4\%; Intel, 9\%; Lucent, 12\%; Microsoft, 17\% (Thurow, 2001:102).

A geração do conhecimento trilha caminhos paralelos ou, às vezes, até coincidentes com a inovação. Para Stewart (2001:183) inovação é uma máquina ou um jardim. Porque ela é uma máquina, as empresas têm que projetá-la, lubrificá-la e gerenciá-la. Porque é um jardim, as empresas devem criar condições sob as quais ela possa florescer.

Para Stewart (2001:184) inovação consome tempo do trabalho diário. Pessoas precisam permissão para fazer isto; mais que isto, elas precisam saber que é parte do trabalho delas fazer mais do que o trabalho delas.

Segundo Leonard-Barton (1995:117) idéias experimentais criam o futuro. Se experimentação é uma atividade importante para criar competências, é claro que gerentes precisam criar um clima organizacional que aceite e encoraje esta atividade. Uma idéia se torna realidade quando exposta por alguém sem receio de virar-se contra tecnologias predominantes ou a cultura da empresa. Quanto mais incerto é o futuro, mais essencial se torna o ambiente no qual qualquer um na empresa está livre para experimentar e aprender; onde fazer protótipos não é 
uma atividade técnica, especializada relegada a engenheiros, mas uma forma de pensar.

A mesma autora (1995:118) segue afirmando ser importante distinguir entre erros inerentes a empresas condenadas e erros resultantes de experimentos criativos. Os últimos são denominados pela autora como “inteligentes" e não são só benéficos como absolutamente necessários. Erros inteligentes são resultados de tomar risco. Se as pessoas não tomam o risco de dizer ou fazer algo ousado, não há espaço para a criatividade. Há uma tendência em se colocar um componente positivo em notícias negativas pois as pessoas são promovidas pelo sucesso, não pela falha.

Em tendo ocorrido a falha, todas as medidas devem ser tomadas para que o máximo de lições sejam extraídas do evento e não que a falha seja encoberta.

Leonard-Barton (1995:131) afirma que não faz sentido levar a cabo experimentos, a menos que os gerentes assegurem que a organização de fato aprenderá com estes exercícios.

Outra forma de gerar conhecimentos é buscar ajuda externa, principalmente com quem conhece bem a empresa, como clientes e fornecedores, ou de universidades, institutos de pesquisa, concorrentes.

Segundo Stewart (2001:195) o mais importante é considerar o fato que a criação de valor, cada vez mais, é a colaboração entre vendedor e comprador. 0 processo de aprendizagem com o cliente precisa ser integrado, abrangendo todas as funções, não somente marketing, vendas e assistência técnica.

Para Leonard-Barton (1995:175) criar uma competência com ajuda externa requer um conjunto de atividades habilidosas como conferir fronteiras porosas à organização, buscando larga e continuamente oportunidades de tecnologia, identificando e usando eficazmente aqueles colaboradores que servem como mantenedores da tecnologia e combatendo a síndrome do "não inventado aqui". 
Para Reisman (1992:19) uma outra abordagem para a geração de conhecimento é que ela pode ser rotulada como transferência de tecnologia.

Uma outra forma de se aprender externamente é através de alianças. Elas valem tanto para a geração de novos conhecimentos quanto para a transferência de conhecimentos existentes.

Para Bruno e Vasconcellos (1997:325) o sucesso da cooperação tecnológica entre empresas depende inicialmente de um alto grau de consistência entre as estratégias dos parceiros e dos objetivos da parceria. Um elemento igualmente essencial seria a abordagem positiva dos participantes. Alianças são implantadas e gerenciadas por pessoas e não por empresas. Por isto a qualidade do relacionamento pessoal determina o grau de confiança desenvolvido e o comprometimento dos indivíduos envolvidos com os objetivos da aliança.

\subsection{DISSEMINAÇÃO DO CONHECIMENTO E COMUNICAÇÃO}

Para Stewart (2001:199), trocar idéias, compartilhar experiências, pedir informações são atitudes naturais e bastante comuns no mundo atual. No trabalho, infelizmente, esta situação não se repete com freqüência. $O$ intuito deste item é discutir o tema, apresentando a visão e as propostas de diversos autores para estimular a disseminação do conhecimento e a comunicação entre a pessoas.

Para Davenport e Prusak (1998:107) a forma mais eficaz de se transmitir conhecimento é contratar pessoas perspicazes e deixar que elas conversem entre si.

Esta frase resume bem o tema. Grande parte das técnicas e estratégias apresentadas pelos autores para transferir conhecimento resume-se a maneiras eficazes de se comunicar, principalmente quando se trata de compartilhar conhecimento tácito que exige intenso contato pessoal. Já o conhecimento explícito pode, mais facilmente, ser transferido através de métodos menos sociais. O que denota a necessidade de observar-se o tipo de conhecimento a ser transferido no momento da escolha da estratégia. 
Conforme Dixon (2000:15), olhando para quem vai receber, qual o tipo de atividade está envolvida, que tipo de conhecimento tem que ser transferido, é possível para as organizações construir um sistema de disseminação do conhecimento para sua situação específica.

Segundo Nonaka (1997:30), o conhecimento novo começa sempre no indivíduo. Tornar o conhecimento pessoal disponível para os outros é a atividade central da empresa criadora do conhecimento.

Choo (2003:197) acredita que apesar de não ser codificável, o conhecimento tácito pode e é normalmente ensinado e compartilhado. $\mathrm{O}$ conhecimento tácito pode ser aprendido por meio de exemplo e compartilhado por meio de formas ricas de discurso, que incluem o uso de analogias, metáforas ou modelos, e mediante o compartilhamento de histórias.

Para Sveiby (1997:87) existem três estruturas não computadorizadas para transmitir conhecimento tácito:

Socialização através de escritórios com ambientes abertos;

Socialização através do acompanhamento dos iniciantes pelos mais experientes ou por equipes, e;

> Internalização via simulação ou jogos.

De acordo com Shaw e Perkins (1993:160), a capacidade de transferir e disseminar conhecimento é conseguida quando há um intercâmbio colaborativo de idéias no qual perspectivas diferentes são expostas e o conhecimento é partilhado. Sem intercâmbio, os conhecimentos obtidos com a ação e reflexão em níveis individual e de grupo não são plenamente compreendidos em nível organizacional. Em conseqüência, a organização repete erros e falhas para adaptar-se às mutáveis condições interna e externa.

Para Sveiby (1997:43), o conhecimento pode ser compartilhado de duas formas: 
Informação transfere o conhecimento indiretamente através da mídia, como leitura e apresentações audiovisuais;

> Tradição transfere o conhecimento diretamente, de pessoa para pessoa, através do aprender fazendo. Neste caso o receptor participa ativamente do processo de transferência.

Davenport e Prusak (1998:107) apontam as seguintes estratégias de transferência do conhecimento:

Conversas em bebedouros ou máquinas de café. Alguns ainda consideram perda de tempo, mas nelas as pessoas se perguntam sobre projetos em curso, trocam idéias e pedem conselho sobre como resolver problemas. Na economia regida pelo conhecimento, conversar é trabalhar.

> Feiras e fóruns do conhecimento. São outra forma de criar locais e ocasiões para funcionários interagirem informalmente. Incentivam a troca de conhecimento com espontaneidade. Normalmente funcionam por serem não-estruturados.

Além do tipo de conhecimento, deve-se levar em consideração a cultura empresarial na definição da estratégia. Algumas organizações ou povos não se sentem à vontade para explicitar seus conhecimentos, preferindo compartilhá-los face-a-face.

Na transferência do conhecimento, assim como na comunicação, é primordial que os interlocutores compartilhem da mesma linguagem.

Segundo Krogh e outros (2001:50), para que se desenvolva a comunicação aberta, direta e construtiva, todos os símbolos de status e de classe social devem ser eliminados. Os autores seguem afirmando que (2001:61) para compartilhar o conhecimento pessoal, os indivíduos devem confiar em que os outros estejam dispostos a ouvir e a reagir às suas idéias. A maneira como as pessoas interagem 
afeta com intensidade a distribuição do conhecimento tácito. O pré-requisito da convivência é a alta solicitude nos relacionamentos organizacionais (2001:76).

Seguindo a mesma linha de raciocínio, Davenport e Prusak (1998:121) afirmam ser o contato direto essencial para estabelecer convívio e eliminar um dos atritos básicos que impedem a efetiva transferência do conhecimento: a confiança mútua.

O processo de transferência do conhecimento nada mais é, do ponto de vista de quem está recebendo a transferência, do que uma aprendizagem.

Vários autores levantam a questão da colaboração entre as pessoas. Em geral, as novas formas desenhadas para gerar e utilizar conhecimento - redes, alianças, federações e o desenho celular - demandam comportamentos colaborativos. O processo de criação e disseminação do conhecimento requer, essencialmente, colaboração.

Trabalhar com colaboração, por sua vez, requer reconhecimento de que o trabalho de todos juntos e o compartilhamento de informação e conhecimento poderão resultar em nível de produtividade e inovação muito maior do que poderia ser alcançado por cada indivíduo separadamente. Requer que a distribuição dos resultados seja também eqüitativa. $E$ também requer que cada pessoa tenha um elevado grau de voluntarismo - o que significa liberdade e igualdade.

Se a geração e a disseminação de conhecimento são fenômenos predominantemente horizontais, ao invés de estruturas hierárquicas tradicionais, é preciso ter formas e conjuntos de processos que estimulam o fluxo e a transferência de conhecimento. O objetivo do gerente passa a ser, então, o desenvolvimento de uma infra-estrutura em que o conhecimento possa ser gerado e comunicado.

Segundo Choo (2003:356) regras, papéis e tecnologias podem ser definidos de antemão pela organização, mas também podem emergir da prática e de conversas entre os participantes. Novas formas de colaboração, comunicação 
e controle estão sendo formadas por novas estruturas organizacionais e pelo uso das tecnologias de informação e comunicação.

Para Stewart (1998:109) o trabalho do conhecimento raramente se movimenta para frente com uniformidade. É uma série aberta de colaborações e compromissos que vão e voltam. Neste contexto, o capital intelectual estruturado pode facilitar o fluxo do conhecimento.

A administração tem que refletir criticamente sobre o que é conhecimento e qual é o contexto compartilhado, além de permitir a discussão e o debate entre as pessoas, ajudar pessoas a descobrir papéis (atual e pretendido) do conhecimento e perguntar às pessoas sobre as implicações que o conhecimento tem sobre comportamentos e processos. Um outro problema delicado é ser preciso corrigir os erros no estoque de conhecimento e, dessa maneira, tem-se que expor o conteúdo continuamente ao escrutínio de todas as formas possíveis. Tudo isso precisa ser gerenciado para que as pessoas sintam que o compartilhamento do conhecimento é uma ação valorizada pela organização.

Para Choo (2003:185) o dilema para uma organização seria, portanto, exteriorizar o conhecimento que pode ser explicitado, para que ele possa ser compartilhado, mas sem comprometer o ímpeto de aprender e inovar.

Senge e outros (1999:487) argumentam que atingir o desafio da difusão depende eficazmente do desenvolvimento de culturas organizacionais que continuamente encorajam as pessoas a atravessar as fronteiras funcionais para indagar e chegar a níveis mais elevados de entendimento mútuo.

A capacidade de uma organização difundir práticas inovadoras depende de (Senge e outros, 1999:490):

Capacidade de orientação. A capacidade de orientação da organização reflete o número de pessoas bem informadas disponíveis para orientação, tutoriamento e ajuda;

Permeabilidade das fronteiras organizacionais; 
Infra-estrutura de informações. As pessoas na organização precisam saber quem procurar e o que perguntar antes que possam começar a aprender com as experiências dos outros. Elas precisam de canais de comunicação para tornar a indagação mais fácil;

Cultura de aprendizagem. Uma cultura organizacional que encoraje reciprocidade, curiosidade e reflexão além das fronteiras internas e externas, bem como uma infra-estrutura eficaz de aprendizagem.

Outra possibilidade para compartilhar e disseminar mais ampla e profundamente conhecimentos é a rotação de pessoal.

Segundo Hamel e Prahalad (1995:270), para alavancar uma competência essencial em vários negócios e novos mercados freqüentemente é necessário redistribuir internamente esta competência, de uma divisão ou unidade de negócios para a outra. Muitas empresas têm um estoque considerável de competências essenciais, mas uma capacidade pequena de redistribuir os indivíduos de acordo com a oportunidade dos novos mercados.

Krogh e outros (2001:243), na mesma linha, afirmam que o compartilhamento de conhecimento também é facilitado por meio da rotação de pessoal entre as unidades independentes.

Segundo Stewart (2001:202) a rotação de pessoal significa um baixo custo de recrutamento e treinamento mais rápido e barato que qualquer outro método. Cita o exemplo da HP, onde cerca de $10 \%$ dos colaboradores movem-se para um novo emprego dentro da empresa a cada ano.

Para Robbins (2002:447) o ponto forte da rotação de pessoal - também denominada rodízio de tarefas - é que ela reduz o tédio e aumenta a motivação através da diversificação das atividades dos funcionários. 


\subsection{COMUNIDADES DE PRÁTICA}

Adicionalmente pode-se citar as comunidades de prática, como uma técnica de geração de novos conhecimentos, bem como de transferência, principalmente, de conhecimento tácito. As comunidades de prática podem ser de assuntos ligados ao negócio ou não, podem ainda ser formais ou informais.

Segundo Wenger e Snyder (2000), comunidades de prática são grupos de pessoas reunidas informalmente para compartilhar experiências pela paixão por uma empresa unida.

Para Turner (1999:552), as comunidades de prática facilitam a movimentação horizontal de informações, além de construírem redes de relações, reunindo as pessoas através de meios que as encorajariam a conhecer umas às outras informalmente.

Stewart (1998:86) considera as comunidades de prática, grupos que aprendem. Surgem por consenso próprio, pessoas atraídas umas às outras por uma força que é tanto social como profissional; elas cooperam de forma direta, sondam-se mutuamente, ensinam umas às outras, exploram juntas um novo assunto. É voluntária, tem vida longa e não tem que gerar um produto específico, como um relatório ou um novo produto. Elas realizam dois trabalhos principais na formação do capital humano: transferência do conhecimento e inovação.

Para Rosenberg (2001:72) a troca de informações ocorre em todas as empresas, mesmo naquelas em que o clima é hostil ao compartilhamento do conhecimento. No entanto, um clima positivo torna o processo mais eficaz e mais confortável para todos. É aí que a comunidade agrega valor. Segundo o autor o gerenciamento do conhecimento estimula o crescimento das comunidades de prática.

Várias características definem as comunidades de prática e as distinguem de outros grupos. Segundo Wenger e Snyder (2000) elas têm o propósito de desenvolver as competências dos seus membros, que são escolhidos por eles mesmos. O que os mantêm juntos são a paixão, o comprometimento e a 
identificação com a experiência do grupo. Como resultado, com o tempo as comunidades desenvolvem costumes, cultura.

Rosenberg (2001:75) afirma que um dos grandes benefícios das comunidades é que elas tendem a ser incubadoras das melhores práticas do futuro. Os membros das comunidades experimentam novas metodologias e idéias e, em seguida, quando estas idéias são comprovadas, eles as inserem na base de conhecimento da empresa.

Terra (2003b) afirma ser a habilidade para organizar, capturar e disseminar o conhecimento de comunidades de prática por toda a organização uma das bases do sucesso da gestão do conhecimento.

Segundo Duguid e Brown (2001:75), o maior desafio está em intermediar o conhecimento entre as fronteiras que delimitam as práticas. $\mathrm{O}$ autor aponta três tipos diferentes de intermediação:

Por participação. Algumas pessoas podem pertencer a várias comunidades. Conseqüentemente, estão em posição de intermediar o conhecimento entre as diferentes comunidades a que pertencem.

> Por tradução. Tradutores organizacionais são aqueles que podem estruturar os interesses de uma comunidade em termos da visão de mundo moldada pela prática de outras comunidades.

Por objetos de fronteira. Os objetos de fronteira estão nas fronteiras de mais de uma comunidade. Eles são de interesse para as comunidades e podem ser objetos físicos, tecnologias, processos, técnicas. 


\subsection{O PAPEL DO LÍDER NA EMPRESA ESTRUTURADA PARA O CONHECIMENTO}

Para Romani e Dazzi (2002:47) um dos grandes desafios nas organizações do futuro é de saber usar o conhecimento de cada um, saber somá-los e saber criar um ambiente de sinergia para alavancar os negócios.

Leonard-Barton (1995:78), na mesma linha, afirma que os gestores precisam ser capazes e estar dispostos a intervir em interações entre grupos opositores - não para suavizar as diferenças mas para canalizar as energias na direção positiva. Gerentes multilinguais - que são capazes de operar em mais de um domínio de especialização em que utilizam mais de um estilo cognitivo administram estas intervenções encorajando os participantes a focar em ambos: no processo e no conteúdo da discussão.

Segundo Drucker (1992:76), a base para uma liderança eficaz na sociedade do conhecimento é compreender a missão da organização, defini-la e estabelecê-la de forma clara e visível. Outro requisito é ganhar a confiança, de outro modo não haverá seguidores, e a única definição de um líder é alguém que tem seguidores.

Nonaka (1997:40) afirma que os gerentes devem propiciar aos funcionários uma estrutura conceitual que os ajude a extrair significado de sua própria experiência. Isso ocorre no nível da alta administração, no topo da companhia e no nível da média gerência, nas equipes de trabalho. Os médios gerentes sintetizam o conhecimento implícito tanto dos funcionários como dos altos executivos, tornam este conhecimento explícito e o incorporam em novas tecnologias e produtos. Neste sentido, são verdadeiros 'engenheiros do conhecimento' da empresa criadora do conhecimento.

Para Senge (1997:345) o papel da liderança nas organizações de aprendizagem difere substancialmente daquele do carismático tomador de decisões. Os dirigentes têm as funções de projetista, guia e professor. Tais papéis envolvem novas habilidades: a capacidade de construir uma visão compartilhada, de trazer à superfície e questionar os modelos mentais vigentes e de incentivar 
padrões mais sistêmicos de pensamento. Eles têm a responsabilidade de construir organizações nas quais as pessoas expandam continuamente sua capacidade de entender a complexidade, definir objetivos, aperfeiçoar modelos mentais e criar o futuro. Ou seja, eles são responsáveis pela aprendizagem.

O mesmo autor segue ainda afirmando (1990:309) que a clareza e a persuasão das idéias, a profundidade de seu empenho, e a disposição para aprender distinguem o dirigente da organização que aprende dos demais.

Drucker (2001:12) defende que a sociedade do conhecimento é muito mais uma sociedade de juniores e seniores que uma sociedade de chefes e subordinados. Na relação com os trabalhadores do conhecimento, o líder deve entender que eles não se identificam como "trabalhadores" mas como "profissionais". Estes trabalhadores têm duas necessidades principais: educação formal, que os habilita a entrar em um trabalho do conhecimento em primeiro lugar e educação continuada através de toda sua vida de trabalho para manter seu conhecimento atualizado. $O$ autor afirma que o conhecimento é nãohierárquico, desta maneira os trabalhadores do conhecimento não se vêm como subordinados e esperam ser tratados como tais.

Raciocínio sistêmico, competência intercultural e treinamento intensivo e contínuo foram algumas das características citadas por Prahalad (1997:185) para descrever o gerente da nova era.

Para Krogh e outros (2001:91) numa empresa criadora de conhecimento, a responsabilidade da administração é dupla: a) identificar o que a organização sabe, qualquer que seja sua forma, e transformar o conhecimento tácito em algo acessível e utilizável; b) garantir a criação de conhecimentos exclusivos, suscetíveis de aproveitamento em atividades criadoras de valor, ou promover a melhor utilização de conhecimentos públicos, em geral disponíveis para a empresa e para seus concorrentes.

Crawford (1994:127) afirma que os gerentes na nova economia do conhecimento são orientadores e facilitadores que não controlam seus 
funcionários, mas sim liberam seu potencial. Tornar-se um treinador, orientador e mentor significa criar um ambiente fértil para o crescimento pessoal.

Clemes (2002:149) afirma que o papel fundamental de um líder em uma organização do conhecimento é criar um ambiente que favoreça a geração, externalização e compartilhamento das diversas formas de conhecimento que sustentam a ação humana.

Segundo Romani e Dazzi (2002:54), percebe-se, ao analisar o estilo gerencial condizente com as organizações do conhecimento, que há necessidade de uma série de características que conduzam a um ambiente participativo. $O$ líder deverá inspirar a confiança das pessoas por meio do desenvolvimento das competências de cada um e do envolvimento mútuo entre todo o grupo; deve ainda: desenvolver um processo contínuo de aprendizagem que possibilite a geração e o compartilhamento do conhecimento; ser capaz de ouvir seus colaboradores e ser comunicativo. Para tanto, é preciso propiciar um ambiente favorável ao diálogo, à liberdade de criação e expressão, respeitando a diferença entre as pessoas.

\subsection{O TRABALHADOR DO CONHECIMENTO}

Segundo Crawford (1994:34) a característica mais marcante da economia do conhecimento é o surgimento do capital humano como força dominante na economia. À medida que novos empregos surgem do processamento de informação e dos serviços do conhecimento, o trabalhador das informações cresce em importância relativa na força de trabalho total.

Sveiby (1997:19 e 57) acredita ser a maioria dos empregados em empresas intensivas em conhecimento composta por profissionais altamente qualificados e instruídos, o que significa que eles são trabalhadores do conhecimento. O trabalho deles consiste na conversão de informação em conhecimento, usando as suas próprias competências, às vezes com a assistência de fornecedores de informação ou conhecimento especializado. Estes profissionais gostam de problemas complexos, novos avanços na profissão deles, 
liberdade para buscar novas soluções, laboratórios bem equipados e reconhecimento público de suas realizações.

Para Drucker (1999:119 e 129) a liderança da economia mundial irá, daqui a 50 anos, para os países e indústrias que elevarem a produtividade dos trabalhadores do conhecimento de forma mais sistemática e bem sucedida. $O$ primeiro requisito em se tratando de trabalho do conhecimento é descobrir qual a tarefa, de forma a possibilitar a concentração nela de trabalhadores do conhecimento. Por outro lado, definir a qualidade em trabalho do conhecimento e converter a definição em produtividade do trabalhador do conhecimento é, em grande parte, uma questão de definir a tarefa. Isto requer a definição do que são "resultados" para uma dada organização e atividade.

Crawford (1994:127) acredita que a habilidade crucial que se deseja nos trabalhadores na economia do conhecimento é a habilidade para pensar: sintetizar, fazer generalizações, dividir em categorias, fazer referências, discernimento de fatos e opiniões e organização de fatos na análise dos problemas.

Segundo Drucker (1998:116) os trabalhadores do conhecimento só podem trabalhar porque existe uma organização; assim, também eles são dependentes. Ao mesmo tempo, porém, eles possuem os "meios de produção": seus conhecimentos. A este respeito, eles são independentes e altamente móveis. $\mathrm{O}$ funcionário do conhecimento pode até precisar de uma máquina, seja ela um computador ou um telescópio, mas a máquina não lhe dirá o que fazer nem saberá como fazer, e sem este conhecimento, que pertence ao funcionário, ela é improdutiva.

Na visão de Crawford (1994:118) os empregados do futuro serão capazes de aprender rapidamente (para poder compreender as circunstâncias de inovação e os problemas) e terão muita imaginação (para poder inventar novas soluções). Eles participarão de pequenos grupos, equipes multidisciplinares, parcerias e círculos de qualidade. Para reforçar a sinergia entre o indivíduo e a organização, os empregadores oferecerão horário de trabalho flexível, ambientes 
intelectualmente estimulantes, movimentação lateral na função exercida, empregos multidimensionais e pessoas mais velhas e experientes trabalhando com pessoas mais jovens.

Para Thurow (2001:131) o maior fator desconhecido para o indivíduo numa economia baseado no conhecimento é como ter carreira em um sistema em que não há carreiras.

\subsection{ESTRUTURA ORGANIZACIONAL E GESTÃO DO CONHECIMENTO}

Segundo Choo (2003:351) o uso da expressão "organização do conhecimento" é uma tentativa de abandonar uma conceituação de conhecimento como objeto ou coisa que tem que ser conquistada e adotar uma visão mais ampla do conhecimento, como um processo contínuo de construção social e coletiva, incorporado nas tarefas, nos relacionamentos e instrumentos da organização.

Krogh e outros (2001:215) afirmam que criar o contexto adequado para a criação do conhecimento envolve estruturas organizacionais que fomentem relacionamentos sólidos e colaboração eficaz. As estruturas organizacionais devem reforçar a interação entre conhecimentos tácitos e explícitos através de muitas fronteiras diferentes.

Segundo Davenport e Prusak (1998:129), para que a gestão do conhecimento possa prosperar, as organizações precisam criar um conjunto de funções e qualificações para desempenhar o trabalho de aprender, distribuir e usar o conhecimento. Há muitas tarefas estratégicas a executar, sendo irrealista presumir que uma empresa possa simplesmente acrescentar atividades de gestão do conhecimento aos cargos existentes.

Para Gerstein e Shaw (1993:242) o projeto organizacional é uma das ferramentas mais úteis no fortalecimento da competitividade das organizações; 
portanto veremos tentativas mais freqüentes e radicais de aumentar a eficiência por meio de estruturas inovativas.

Quinn e outros (2002:148) acreditam que nenhuma forma organizacional é uma panacéia. Na realidade muitas formas diferentes freqüentemente coexistem com sucesso na mesma empresa. Adequadamente utilizada, cada uma delas ajuda a empresa a atrair, reter, alavancar e empregar o intelecto para objetivos bem diferentes. Conseqüentemente, cada uma delas exige um conjunto cuidadosamente desenvolvido de normas culturais apoiadas por programas de computador e por sistemas de avaliação de desempenho e recompensas adaptados para os objetivos específicos da organização.

\subsubsection{Novos Desenhos Organizacionais: Estruturas Específicas para Organizações do Conhecimento}

Diversos autores dedicaram-se ao estudo e desenvolvimento de modelos alternativos específicos para organizações interessadas em administrar o conhecimento de maneira mais sistemática. Estas empresas são freqüentemente rotuladas de "Empresas de Conhecimento Intensivo", cuja definição é simplesmente uma organização em que o recurso-chave é o conhecimento e a expertise, segundo Starbuck (citado por Caldas e Wood Jr, 1999:280). A seguir apresentamos alguns exemplos:

\section{ORGANIZACCÃO INVERTIDA - Quinn e outros (2002)}

Quinn e outros (2002:142) apresentam a NovaCare - empresa americana de assistência à saúde - como exemplo de organização invertida, onde os profissionais são extremamente auto-suficientes e têm uma enorme autonomia. $A$ alavancagem da estrutura organizacional da NovaCare é distributiva, ou seja, a organização de apoio distribui eficazmente o apoio administrativo, logístico e de análise aos profissionais. Mas não lhes dá ordens. A antiga linha hierárquica se torna a estrutura de apoio, intervindo apenas em emergências extremas. A função dos antigos gerentes de linha muda: em vez de dar ordens, estão agora removendo barreiras, acelerando recursos, realizando estudos e atuando como 
consultores. Sistemas invertidos raramente funcionam até que o pessoal de campo determine amplamente os salários, promoções e progresso organizacional do seu "pessoal de apoio".

\section{ORGANIZAÇÃO FLEXÍVEL - Angeloni (2002)}

Angeloni (2002:xx) salienta a importância que a organização disponha de uma estrutura organizacional flexível. As estruturas rígidas propostas pelos teóricos do início do século, como Taylor e Fayol, entre outros, não são mais adequadas a um ambiente organizacional que exige uma rápida e constante (re)adaptação do meio organizacional e efetiva participação de todos os colaboradores da organização. Seria interessante ainda desaprender práticas passadas, sendo necessário para isto trabalhar modelos mentais.

\section{ORGANIZAÇÃO INOVADORA - Galbraith (1997)}

Galbraith (1997:190) apresenta uma proposta de estrutura organizacional adequada à organização inovadora. Esta estrutura pressupõe a coexistência de duas estruturas nas organizações, uma inovadora e outra operacional. À estrutura inovadora cabe a concepção das idéias, e à estrutura operacional cabe implantálas. Para isto é necessário que se estabeleça um processo de integração que possibilite a transferência das idéias de uma estrutura para a outra.

Ela é uma combinação de pessoas geradoras de idéias, reservas onde elas possam operar, patrocinadores para orientá-las, alocação de recursos para suas idéias e recompensas por seu sucesso que aumentam as probabilidades de inovação.

\section{ORGANIZACCÃO COLATERAL - Kilmann (1997)}

Kilmann (1997:219) apresenta como alternativa para as organizações atuais a implantação de uma estrutura mista, que mescle o desenho tradicional com uma estrutura colateral voltada para a solução de problemas não rotineiros, complexos e que exigem criatividade. Nesta proposta, as pessoas que compõe a 
estrutura colateral são provenientes de diferentes departamentos da estrutura operacional, o que torna disponível dentro de cada grupo uma vasta gama de qualificações e informações.

A organização colateral tem alguma semelhança com a matricial no sentido que envolve dupla chefia, porém o autor considera que existam duas importantes exceções. Primeira, é possível que vários membros do desenho colateral possam ter o mesmo chefe que têm no desenho operacional. A segunda envolve uma diferença fundamental no aspecto de foco. Na maioria dos casos as equipes matriciais seriam orientadas para a solução de problemas do tipo 'autoridadeprodução', enquanto o desenho colateral concentraria-se na definição e solução de problemas pouco definidos, complexos e de longo prazo, não em problemas de 'autoridade-produção'.

\section{ORGANIZAÇÃO EM HIPERTEXTO - Nonaka e Takeuchi (1997)}

Nonaka e Takeuchi (1997:192) apresentam a organização em hipertexto que permite a exploração, a criação, a acumulação e a transferência do conhecimento de forma eficaz, contínua e repetitiva. O pressuposto básico deste modelo é de que a criação do conhecimento humano ocorre por meio da interação social entre o conhecimento tácito e o explícito. Uma organização do conhecimento deve ter uma estrutura não-hierárquica e auto-organizada, que funcione em conjunto com a estrutura hierárquica formal. Esta organização em hipertexto idealizada pelos autores é constituída de três níveis interconectados: o sistema de negócios, a equipe de projeto e a base de conhecimento.

O sistema de negócios representa o nível em que são realizadas as tarefas rotineiras da organização, caracterizado por uma estrutura burocrática, formal e hierárquica.

O nível equipes de projeto representa a reunião de pessoas oriundas de diferentes unidades para compor equipes engajadas em atividades criadoras do conhecimento. As pessoas destas equipes estão envolvidas exclusivamente com o projeto para o qual foram designadas, sendo desvinculadas, enquanto durar o 
projeto, do sistema de negócios. O conhecimento gerado nos níveis sistema de negócios e equipes de projeto é reclassificado, recontextualizado e registrado no nível base de conhecimento.

Este nível não existe como uma entidade organizacional real, está incorporado à visão da empresa, à cultura e à tecnologia.

\section{FUNÇÃO INOVAÇÃO TECNOLÓGICA - Kruglianskas (1996)}

Kruglianskas (1996, citado em Terra, 1999:108) propôs uma alternativa para o desenvolvimento tecnológico na pequena empresa que não tem condições de ter um departamento formal de Pesquisa \& Desenvolvimento. Envolve uma ação estruturada, dirigida por objetivos estratégicos e pressupõe o trabalho conjunto de pessoas de diferentes departamentos e níveis hierárquicos, através de comitês.

É uma estrutura matricial do tipo Inovação / Rotina onde os comitês voltados à inovação tecnológica operam horizontalmente segundo uma perspectiva de médio e longo prazo e a estrutura funcional, verticalmente, com a preocupação de resultados de curto prazo.

\section{ORGANIZACẼ̃O EM REDE}

O termo organização em rede foi utilizado por diversos autores. Porém, nem todos compartilham da mesma visão. Apresenta-se a seguir as idéias de alguns pesquisadores.

Chiavenato (1999:687) apresenta a rede dinâmica. A estrutura em rede significa que a organização desagrega suas funções principais e as transfere para empresas separadas que são interligadas por uma pequena organização coordenadora, que passa a constituir o núcleo central. A companhia central retém o aspecto essencial do negócio, enquanto transfere para terceiros aquelas atividades que as outras companhias podem fazer melhor e mais barato. 
Gerstein (1993:22), por sua vez, afirma que na organização em rede as reservas de bens, conhecimentos e competências são distribuídas, isto é, situadas em múltiplas localizações. Ao desenvolver novos produtos, por exemplo, algumas unidades lideram e outras fornecem apoio. A interdependência entre as entidades é facilitada segundo a necessidade de metas comuns, processos administrativos e incentivos comuns. O sistema de valor da organização é caracterizado pela partilha e colaboração; confiança; autoridade e valorização do conhecimento.

Na visão de Quinn (1992:120) o termo rede não é o mais adequado para descrever este tipo de organização. O autor denomina-a "teia de aranha" pela leveza das suas interconexões. A organização em "teia de aranha" opera essencialmente sem - ou com um mínimo - de autoridade formal. Unidades individuais poderiam operar completamente independentes caso a economia de escala ou o escopo não sejam benéficos para a organização toda. Esta estrutura pode ser usada por parte da organização quando conveniente, mesmo que o restante da organização opte por outra estrutura.

Para Quinn e outros (2002:146) um fator chave de alavancagem que está nas teias de aranha é a tecnologia. A eletrônica permite que talentos muito mais diversos, geograficamente dispersos e intelectualmente especializados sejam trazidos para um único projeto.

Segundo Quinn (1992:124) quando as organizações operam na fronteira do conhecimento, a autoridade está naquele que tem mais informação; conseqüentemente existe pouca necessidade de estruturas de autoridade formal. Todos os nós de uma organização em "teia de aranha" estão diretamente conectados por vínculos de comunicação, e as interconexões são usadas com freqüência.

\subsubsection{Delegação de Poderes}

Segundo Davenport e Prusak (1998:204) o que torna o conhecimento valioso para as empresas é, em última instância, a capacidade de tornar melhores as decisões e medidas tomadas a partir dele. 
Para Shaw (1993:150) a responsabilidade clara com a autoridade de agir aumenta a probabilidade de que as pessoas resolvam problemas críticos. $O$ estilo de administração da organização deve criar a expectativa de que os administradores com autoridade para agir têm responsabilidade, e são apoiados no exercício da sua autoridade. Os controles são minimizados e liberados os recursos para as iniciativas de alta prioridade. Algumas medidas estruturais apóiam a delegação de poderes nas organizações:

Reestruturar as unidades para serem menores, menos complexas e menos dependentes de outras unidades nas decisões e na ação;

Reduzir ao mínimo o número de regras fixas na organização. Essas poucas regras ou políticas devem definir claramente como a organização vai operar;

> Realizar uma mudança por toda a organização, centrada na delegação de poderes e responsabilidade pessoal pela produção de resultados;

Proporcionar educação e treinamento necessários para que as pessoas respondam às oportunidades de melhorar.

Para Mintzberg (citado por Terra, 1999:50), muito da dificuldade em delegar advém do fato de os gerentes não conseguirem explicitar boa parte do seu conhecimento.

A liderança sob conceito de Empowerment foi introduzida por Blanchard e outros (1996). O Empowerment é um conceito através do qual os gerentes, gradualmente, transferem às equipes de trabalho a responsabilidade e a autoridade - condições essenciais para um desempenho superior. Empowerment não é dar poder às pessoas mas, antes, liberar as pessoas para que possam fazer uso do poder, dos conhecimentos, das habilidades e da motivação que já têm. Para que isto ocorra é necessário que os gerentes criem condições favoráveis de aprendizado, ação e decisão para que as pessoas possam fazer uso da autonomia e assumir a iniciativa e a responsabilidade pela coleta e análise 
de dados e pela tomada de decisões o que, nas organizações tradicionais é atribuição quase exclusiva dos gerentes.

Uma forma de delegação de poderes é a descentralização. Para Senge (1990:251) descentralizar significa transferir as decisões para baixo na hierarquia organizacional, dar liberdade de ação, deixando que as pessoas testem suas idéias e assumam a responsabilidade dos resultados assim obtidos. $\mathrm{Na}$ organização de aprendizagem, na opinião do autor, é preciso mesclar raciocínio e ação em todos os indivíduos.

\subsubsection{Diretor do Conhecimento (CKO - Chief Knowledge Officer)}

Começa a ser perceptível a presença do Diretor do Conhecimento no organograma das organizações preocupadas com o seu mais valioso capital - o conhecimento.

Foi Peter Drucker (citado por Terra, 1999:27), que cunhou, há quatro décadas, o termo trabalhador do conhecimento e foi, provavelmente, um dos primeiros teóricos organizacionais a chamar a atenção e a avaliar as implicações para o fato de tanto o trabalho técnico como o não técnico serem, cada vez mais, baseados no conhecimento. Desde então Drucker continua a destacar que se avançou muito pouco na formulação de uma teoria econômica que leve em consideração o conhecimento como principal recurso para a produção de produtos e serviços. Além disto a própria gestão deste tipo de profissional continuaria a ser um dos principais desafios gerenciais.

Terra (1999:27) destaca que reconhecendo este desafio, algumas empresas estão, entretanto, criando funções centrais como a do Gerente do Conhecimento. A bibliografia recente destaca neste esforço, as grandes empresas de consultoria internacional, como a PriceWaterhouseCoopers, além de algumas outras empresas como Skandia, HP, GE, Dow Química, ...

O CKO trabalha junto ao CEO (Chief Executive Officer) e os responsáveis pelas áreas de TI (Tecnologia da Informação) e RH (Recursos Humanos), para adequar a administração do conhecimento à estratégia global da companhia. 
Para Krogh e outros (2001:42) esse executivo tem várias atribuições: formular a visão da empresa quanto aos conhecimentos almejados, desenvolver sistemas de gestão do conhecimento, implementar plataformas de tecnologia de informação para ajudar a construir "redes de conhecimento", determinar o valor do capital intelectual da organização e projetar sistemas de remuneração que impulsionem o desenvolvimento de competências. Também deve facilitar as condições que possibilitam a criação de conhecimento, como o estímulo ao feedback regular pelos clientes.

A primeira tarefa desse profissional é estender a infra-estrutura de tecnologia necessária, inclusive aplicações que capturem, categorizem e recuperem informações inseridas por funcionários ou armazenadas em bancos de dados da empresa. O CKO precisa trabalhar continuamente em novas aplicações para acrescentar funcionalidade, proporcionalidade e eficiência àquele sistema.

As responsabilidades adicionais do CKO são educacionais e estratégicas. Ele deve ensinar aos funcionários quais recursos estão disponíveis e como usar o sistema. A meta é criar um agrupamento de informações on-line, como propostas de projetos anteriores, metodologias de tarefas, melhores práticas, transcrição de reuniões e documentação das experiências dos projetos de funcionários que podem ser úteis em projetos adicionais ou em treinamento contínuo.

O diretor de conhecimento precisa conhecer e compreender a empresa em que trabalha e o mercado em que ela atua; não precisa ser programador, mas precisa saber exatamente o que solicitar aos programadores.

Um profundo entendimento de como os indivíduos realmente trabalham em equipe é crucial. Para exercer as funções de um CKO, o executivo precisa possuir habilidades técnicas acentuadas no controle da infra-estrutura em tecnologia.

Para Davenport e Prusak (1998:139) três responsabilidades do CKO são particularmente críticas: construir uma cultura do conhecimento, criar uma infraestrutura para gestão do conhecimento e tornar toda a atividade do conhecimento economicamente compensadora. 
A necessidade de criação desse cargo surgiu quando as grandes companhias perceberam que as intranets poderiam divulgar informações preciosas que antes demorariam a ser difundidas.

Cresceu com o advento da globalização e os ciclos de negócios, para acelerar a habilidade de uma corporação para conectar as pessoas e informações certas e a determinados projetos. Mas a administração de conhecimento efetiva era difícil até o desenvolvimento de tecnologias da Internet, especialmente as pesquisas e tecnologias colaboradoras.

Segundo Davenport e Prusak (1998:141) a estrutura e os relacionamentos de subordinação da função de CKO e sua respectiva organização são também importantes - não só para as atividades cotidianas - mas também pelo seu valor simbólico. Há geralmente três opções para a localização da função de CKO no organograma da empresa. Pode ser um alto cargo independente ou então combinado com a função de Recursos Humanos $(\mathrm{RH})$ ou de Sistemas de Informação (TI). Entretanto, combinar gestão do conhecimento com RH ou TI tende a diluir a importância do conhecimento. A situação ideal é, portanto, uma função independente.

A criação de um sistema nervoso central de uma companhia, que reunirá disciplinas múltiplas que a empresa possuía, mas estavam dispersas, também constitui uma das funções do CKO.

Para Davenport e Prusak (1998:144), a função de Diretor do Conhecimento é particularmente apropriada em empresas nas quais o conhecimento é um recurso essencial para os negócios. Porém em algumas empresas com estas características pode não ser viável a criação de um cargo como este. A organização pode ter uma estrutura organizacional tão descentralizada que um papel central ligado ao conhecimento não seria recomendável. Outro motivo da não introdução do cargo seria pelo fato de outros gerentes já desempenharem esta função. 


\subsubsection{Diretoria do Conhecimento}

Em organizações grandes, o diretor do conhecimento monta uma equipe para auxiliá-lo na tarefa. Este grupo constitui, então, a Diretoria do Conhecimento.

Davenport e Prusak (1998:147) defendem a adoção desta equipe afirmando que, se existe um princípio supremo a se ter em mente com relação a funções e responsabilidades ligadas ao conhecimento, esse princípio é que elas devem ser cargos reais que exigem recursos específicos. Uma das razões apontadas pelo autor para o conhecimento não ter sido bem gerido no passado seria que ninguém era claramente responsável por ele. No conturbado ambiente atual dos negócios, poucos funcionários poderão combinar as responsabilidades da gestão do conhecimento corporativo com as suas funções atuais.

Kahaner (1996:45), que estudou mais detalhadamente o pilar "inteligência competitiva", argumenta que esta equipe em grandes organizações costuma estar vinculada ao planejamento estratégico que se reporta diretamente a alta administração. O autor enfatiza, entretanto, que o local onde este departamento está colocado não é tão importante quanto o fluxo de comunicação que ele consegue estabelecer. Esta equipe deve estar próxima aos usuários primários, mas acessível a qualquer um na organização.

Esta diretoria deve trabalhar em conjunto principalmente com a área de recursos humanos $(\mathrm{RH})$, a área de tecnologia da informação $(\mathrm{TI})$ e as unidades de negócios.

Algumas das suas atribuições são:

Identificar e conceituar processos de conhecimento complementar, principalmente aqueles que permeiam diversos departamentos;

Criação e gerenciamento do programa de captura e disseminação de conhecimento;

Alinhar as táticas e estratégias de conhecimento com as da empresa; 
$>$ Criar e disponibilizar mecanismos de disseminação de capacidades (especialistas) e conhecimentos através da empresa.

Em conjunto com o $\mathrm{RH}$, teria ainda as seguintes atribuições:

$>$ Prover programas de treinamento e educação;

> Instituir incentivos pessoais para motivar a criação, compartilhamento e uso do conhecimento;

Coordenar e direcionar os programas de aprendizagem integrada.

Em conjunto com a TI:

$>$ Criar a infra-estrutura de TI.

Com as unidades de negócios:

Disponibilizar o conhecimento no ponto de utilização;

Incentivar a geração de conhecimento;

Promover o uso do conhecimento.

Outras atividades, relacionadas com mais de um dos departamentos citados:

Estabelecer requisitos de conhecimento para a qualidade do trabalho;

Operar as "homepages" dos funcionários; 
Operar as "páginas amarelas" da empresa;

Operar o sistema de "lições aprendidas";

Operar avaliação dos funcionários com relação aos temas de conhecimento;

$>$ Construir e manter um banco de dados dos colaboradores;

Gerenciar a memória da organização.

Para Bill Gates (1999:72), o bom gerenciamento do conhecimento, nos processos administrativos e internos, é uma maneira importante de melhorar a eficiência dos funcionários como um todo. Quando os funcionários vêem uma empresa eliminar gargalos e tarefas administrativas rotineiras que absorvem tempo em suas atividades, os funcionários acreditam que a empresa valoriza o tempo deles - e quer que o usem de forma rentável.

\subsection{EXEMPLOS}

Após a revisão dos modelos propostos por diversos autores, e de uma descrição de cargos ligados ao conhecimento, busca-se mostrar nesta etapa a forma como conceitos da gestão do conhecimento interagem na gestão moderna dos negócios. Optou-se por demonstrar citando o exemplo de duas empresas que, reconhecidamente, destacam-se na implantação de um sistema de Gestão do Conhecimento.

\subsubsection{O Exemplo da Skandia}

Esse modelo, ao invés de conflitar radicalmente com estruturas tradicionais das organizações, dá o tom destacável de modernidade necessário à gestão empresarial na era do conhecimento e da informação. Assim, foi proposto o modelo NAVEGADOR DE CAPITAL INTELECTUAL da Skandia, segundo Edvinson e Malone (1996:59), como forma de introduzir conceitos novos da 
Gestão do Conhecimento. O texto apresentado neste item tem como base fundamental o texto destes autores.

A figura a seguir visa demonstrar a integração estratégica interagindo com a estrutura de gestão focalizada no capital intelectual:

ESTRUTURA TRADICIONAL

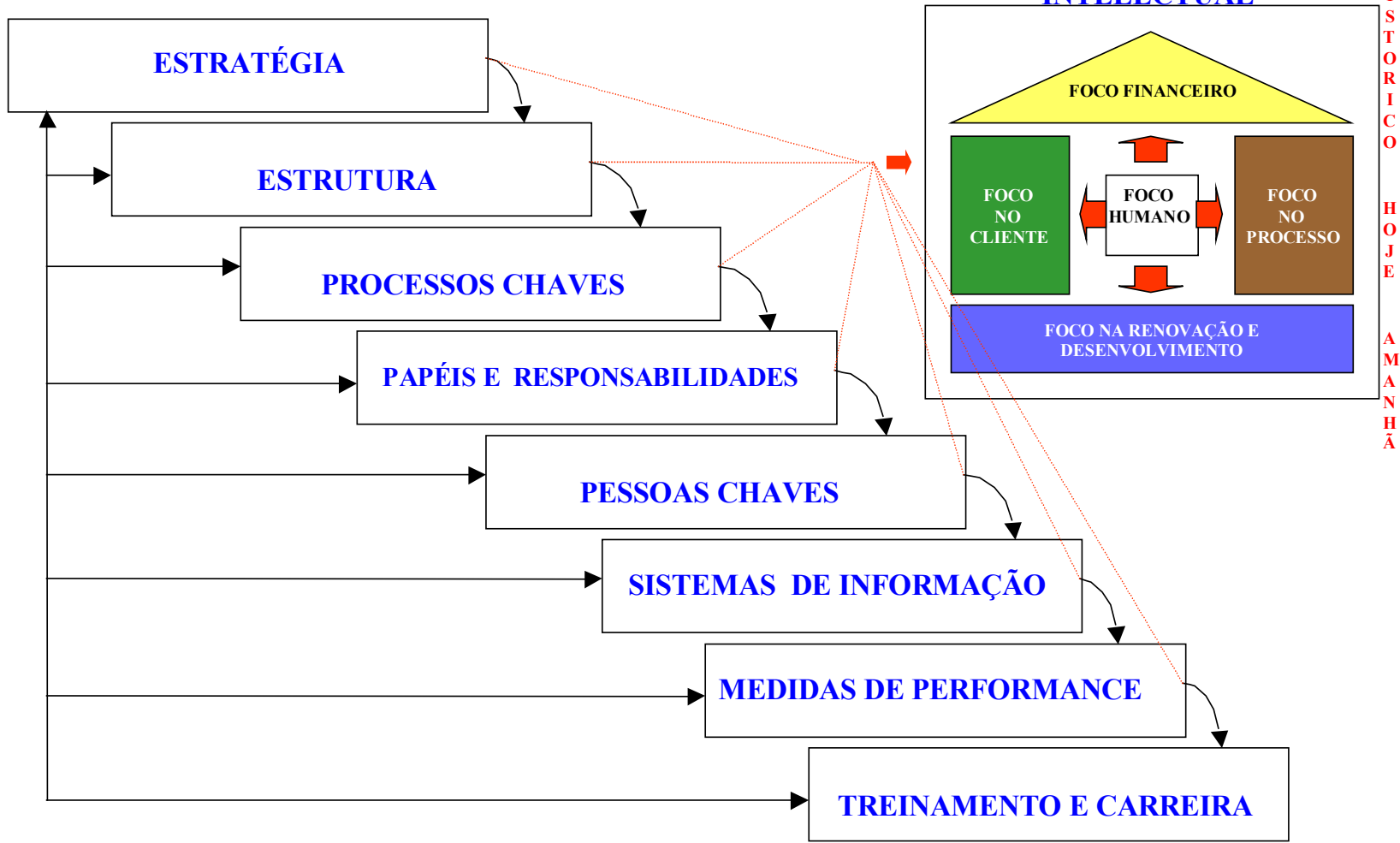

Figura 10. Estrutura de Gestão Voltada para o Capital Intelectual Fonte : Edvinson e Malone (1996:59)

O capital intelectual deve ter posição independente, destacada para interagir com o mais altos escalões da empresa, mas em absoluta harmonia com as metas estabelecidas, das quais deve ser parte integrante. Independente de como as organizações optem por suas estruturas de gestão, como por exemplo: 
> Por Função - Presidência, Finanças, Produção, Vendas, HR, ...

> Por Linha de Produto - Presidência, Diretoria Produto A, Diretoria Produto $B, \ldots$

> Por Segmento - Presidência, Clientes Automotivo, Linha Branca, Doméstico, ...

Por Geografia - Presidência, Americas, Europa, Asia, ...

> Por Cliente - Presidência, Diretoria Shopping Centers, Diretoria Varejo, Diretoria Clientes A, ...

É, pois, notório que organizações modernas que buscam o sucesso nos tempos contemporâneos devem ater-se mais e mais na gestão do seu capital intelectual, pois, é vital a gestão desse capital, seja qual for o modelo estratégico escolhido. Evidencia-se, como citado anteriormente, um número crescente de Diretorias do Conhecimento por se perceber a vantagem competitiva que isso pode representar.

A gestão desse ativo deve tomar em conta a ciência do conhecimento, das relações entre as pessoas e idéias e da fonte renovável de recursos que deve ser cultivada e retida para estabelecimento do valor adicionado das organizações.

Assim, como contraponto ao visto no item 4.8.4, para os autores, na Skandia, a criação de uma Diretoria do Conhecimento deve, entre outras funções, assegurar:

O suporte a estratégia geral de gestão;

A medição do anteriormente não mensurável: mais valia do Capital Intelectual;

A elaboração de dados além dos tradicionalmente contábeis financeiros; 
> A captura e reprodução do conhecimento para melhoria da gestão dos negócios;

$>$ O estabelecimento de políticas de desenvolvimento e retenção dos talentos humanos;

$>$ O apoio à gestão dos clientes.

Acima de tudo, a alta administração deve estar comprometida com os valores muitas vezes intangíveis apontados na gestão do conhecimento, mas certamente de diferencial competitivo dos negócios.

\subsubsection{O Exemplo da BUCKMAN LABORATÓRIOS}

Os dados deste exemplo foram coletados na página da empresa na Internet e em Buckman (2000).

A Buckman Laboratórios é uma empresa privada americana da área química, com 1250 funcionários.

Desde a sua fundação, em 1945, sempre se preocupou em criar e fabricar soluções únicas e inovadoras. Dr. Stanley Buckman começou as suas operações com apenas 5 funcionários produzindo componentes químicos para fabricação de papel. Nas décadas de 50 a 70 a empresa cresceu e expandiu-se para diversos países em vários continentes, tornando-se uma multinacional. Neste período foi também criado o centro de Pesquisa e Desenvolvimento.

Em 1978, com a morte do Dr. Stanley, assume a empresa o seu filho, Robert (Bob) Buckman, que já trabalhava na empresa desde 1961, com vendas de US\$ 29 milhões. Desde o início Bob pretendeu mudar o estilo de liderança da empresa.

Uma das primeiras atitudes foi estabelecer o Código de Ética e a Missão da empresa. Foram impressos em tamanho pequeno, para que coubesse na carteira, e entregue para todos os funcionários. 
Em 1986 a Buckman iniciou um processo mais sistemático de atuação dentro da filosofia de "melhores práticas". Primeiramente foi criado um banco de dados ao qual todos os gerentes gerais estavam conectados usando e-mail em estações IBM ligadas em rede.

Bob não ficou satisfeito pois entendia que as pessoas que realmente necessitavam de acesso à informação e às melhores práticas, eram aquelas que estavam em contato direto com o cliente. O próximo passo foi dar acesso a este pessoal.

Após um ano o primeiro sistema formal de captura e compartilhamento de conhecimento dentro da empresa tinha iniciado suas operações, usando arquivos eletrônicos para gravar como homens de vendas criavam conhecimento novo dentro da organização. Nesta época eles já resolviam problemas dos clientes usando "conhecimento existente" ou desenvolvendo "novos conhecimentos". No final da década de 80, se o departamento coorporativo de Marketing aceitasse o envio de um "novo conhecimento" o autor receberia US\$100. Alguns anos depois este valor foi elevado para US\$200.

Ainda no final da década de 80 , Bob decidiu propor que $25 \%$ das vendas tivessem origem em produtos com menos de cinco anos. A média, na época, era $14 \%$.

Bob analisou diversas empresas e percebeu que a informação obtida, independente da fonte, percorria quase sempre o mesmo caminho: da pessoa que recebeu a informação ela passava sucessivamente por diversos outros funcionários, que adicionavam as suas perspectivas da sabedoria para fazer aquilo ainda melhor. Finalmente ela atingia um guru que realçava a informação com suas "infinitas sabedoria e experiência". A partir daí a informação ou voltava lentamente para a linha de operação da empresa ou ficava depositada em algum banco de dados. Graças a esta embaraçosa corrente de conhecimento, quando a informação chegava ao guru, a fonte não mais a reconhecia.

Então ele decidiu eliminar este caminho tortuoso. 
Bob começou a imaginar maneiras de acessar o conhecimento inconsciente da organização. Se o grande banco de dados da empresa está na mente das pessoas que lá trabalham, então também lá está o poder. Ele passou a procurar respostas de como manter as pessoas conectadas e como compartilhar os conhecimentos. Decidiu criar um sistema de transferência de conhecimento, com as seguintes características:

Diminuir a quantidade de transmissões de conhecimento entre indivíduos, para evitar a distorção da informação;

Dar acesso a todos para a base do conhecimento da organização;

Permitir a qualquer funcionário entrar com conhecimento no sistema;

Funcionar 24 horas por dias, 7 dias por semana;

Ser simples, mesmo para aqueles que não são peritos em computação;

Comunicar em linguagem fácil;

Atualizável automaticamente - o acúmulo de perguntas e respostas deveria gerar a base do conhecimento para o futuro.

Em 1992 Bob criou o Departamento de Transferência de Conhecimento que reportava-se diretamente a ele. A primeira decisão foi possibilitar o acesso externo à rede da empresa e equipar cada vendedor com um computador portátil com modem.

A equipe deste novo departamento iniciou a construção do chamado "K'Netix", um sistema de fácil uso para transferência de conhecimento entre funcionários. O coração do K'Netix eram suas áreas livres, onde qualquer um podia enviar uma mensagem, pergunta ou solicitação de ajuda. Eram chamados de "fóruns". Existiam diversos fóruns, o mais concorrido era o técnico. Havia o objetivo de se encontrar as respostas em 24 horas. 
Em 1994 foi convocada uma reunião da alta administração em um resort, para a qual foram também convocados os 150 melhores compartilhadores de conhecimento. Neste mesmo ano as vendas estavam em US\$246 milhões e os gastos com o programa de compartilhamento de conhecimento alcançaram US\$ 8.4 milhões.

Em 1996 a empresa decidiu focar suas atividades em três áreas que representavam $75 \%$ das suas vendas: papel, couro e água. Além disto decidiu não mais se apresentar como uma empresa fornecedora de produtos químicos, mas de pessoas e a capacidade delas de resolverem problemas.

Em 1998 existiam 27 fóruns globais com acesso irrestrito e 24 fóruns abertos para algumas comunidades. Havia mais de 1700 histórias (cases) em inglês e mais de 600 em espanhol.

No início de 1999 o K'Netix passou a ser reconhecido internacionalmente. Mais de 30 empresas visitaram recentemente a Buckman para aprender algo sobre o K'Netix. O Departamento de Transferência de Conhecimento transformouse em Vice-Presidência de Transferência de Conhecimento.

Para Graham e Pizzo (2002:29) a beleza do K'Netix é seu estreito alinhamento com a estratégia essencial de negócios da empresa.

As vendas alcançaram US $\$ 300$ milhões e $34 \%$ das vendas são originadas de produtos com menos de cinco anos de existência.

Ela foi a vencedora do prêmio MAKE 2000, tendo vencido em cinco dos quesitos apresentados. Isto demonstra que, para obter sucesso na gestão do capital intelectual, tamanho não é tudo. 


\subsubsection{Conclusão dos Exemplos}

As duas empresas apresentadas nos exemplos anteriores mostraram grande preocupação com os ativos do conhecimento e acharam, cada qual à sua maneira, uma forma de contemplar esta importância na estrutura organizacional.

Nos dois casos as empresas possuem executivos de nível sênior responsáveis pelo conhecimento. Entretanto, cada um destes profissionais é orientado de funções diferentes e está engajado em atividades diferentes.

O principal executivo do conhecimento na Buckman Laboratórios é um especialista em Tecnologia da Informação cuja principal responsabilidade é supervisionar a rede informatizada do conhecimento na empresa, enquanto na seguradora sueca Skandia, o diretor de Capital Intelectual tem uma formação financeira e lidera o desenvolvimento de uma ferramenta de medição orientada por conhecimento (Graham e Pizzo, 2002:39).

Isto demonstra não existir uma regra geral para implantação de Gestão do Conhecimento. Os casos devem ser estudados em função das necessidades e das características específicas de cada organização. 


\section{CAPÍTULO 5}

Metodologia de

Pesquisa

"A tarefa não é contemplar o que ninguém ainda contemplou, mas meditar, como ninguém ainda meditou, sobre o que todo mundo tem diante dos olhos." 


\title{
CAPÍTULO 5: Metodologia de Pesquisa
}

\begin{abstract}
Esta pesquisa foi dividida em duas partes principais. A primeira parte compreende um levantamento bibliográfico constituído de um conjunto de pensamento de vários autores sobre os assuntos relacionados aos temas centrais desta pesquisa: Estrutura Organizacional e Gestão do Conhecimento, com o objetivo de se ter uma visão completa e atualizada das reflexões já realizadas por outros pesquisadores.
\end{abstract}

A segunda parte é relativa à pesquisa de campo. A revisão da literatura representa um papel importante no desenvolvimento e conceituação dos tópicos pertencentes aos temas de pesquisa, porém, devido à complexidade e pouca exploração da relação entre as disciplinas Estrutura Organizacional e Gestão do Conhecimento, torna-se fundamental a realização de uma pesquisa empírica, exploratória e qualitativa, sendo utilizado o método de estudo de caso, com a finalidade de se compreender a aplicabilidade dos conceitos nas empresas estudadas.

Este capítulo do projeto apresenta a metodologia de pesquisa adotada para o presente trabalho.

Na primeira seção deste capítulo são feitas algumas considerações básicas sobre metodologias de pesquisa e procedimentos para coleta de dados. $\mathrm{Na}$ segunda seção apresenta-se uma justificativa para a opção metodológica e o delineamento do estudo. A terceira seção propõe um modelo conceitual que servirá como base para o modelo referencial da metodologia que é detalhado na quarta seção, incluindo o detalhamento das variáveis, o levantamento dos dados, questionários e correlatos. Na quinta seção oferece-se a explicação do critério de seleção dos casos e da escolha do ambiente de pesquisa: o setor da economia onde será desenvolvido o estudo. 


\subsection{CONCEITOS BÁSICOS}

Gil (1996:19) define pesquisa como o procedimento racional e sistemático que tem como objetivo proporcionar respostas aos problemas que são propostos. A pesquisa é desenvolvida mediante o concurso dos conhecimentos disponíveis e a utilização cuidadosa de métodos, técnicas e outros procedimentos científicos.

Ao buscar uma metodologia para o desenvolvimento do tema de um trabalho, o pesquisador deve procurar na literatura especializada o método mais adequado para desenvolver a pesquisa para resolver o problema escolhido. Para o resultado de uma pesquisa ser considerado científico, mesmo que ele não possa ser validado, pode-se validar o método. Se a metodologia usada pode ser considerada científica, o resultado também o será.

Para Lakatos \& Marconi (2000:46) método é o conjunto de atividades sistemáticas e racionais que, com maior segurança e economia, permite alcançar o objetivo - conhecimento válidos e verdadeiros - traçando o caminho a ser seguido, detectando erros e auxiliando as decisões do cientista.

Por sua vez, Oliveira (2001:57) define método como uma forma de pensar para se chegar à natureza de um determinado problema, quer seja para estudálo, quer seja para explicá-lo.

A determinação da metodologia a ser adotada na solução do problema de pesquisa é fator fundamental para se obter sucesso de maneira produtiva e eficaz. Por isto faz-se necessário o estudo das técnicas existentes para garantir a qualidade da escolha.

O pesquisador, antes de mergulhar profundamente em seu trabalho, precisa planejar e definir o seu objetivo. O conhecimento prévio das diversas possibilidades de classificação, bem como das diferentes maneiras de abordar o problema, facilitarão a escolha pelo pesquisador do tipo de pesquisa que ele deseja realizar. Ou, sob outro ponto de vista, conhecendo-se o problema de pesquisa a ser desenvolvido, o pesquisador pode determinar qual tipo de pesquisa é o mais adequado. Ao definir o tipo de pesquisa o pesquisador pode 
concluir qual a metodologia a ser empregada no desenvolvimento do trabalho com maior facilidade.

\subsubsection{Tipos de Pesquisas}

A definição dos tipos possíveis de pesquisa não é consenso na literatura. Mattar (1994:80) faz um levantamento detalhado das diversas classificações dos tipos de pesquisa segundo onze autores e, por fim, adota a seguinte classificação:

> Pesquisas exploratórias. Visam prover o pesquisador de um maior conhecimento sobre o tema. São apropriadas para os primeiros estágios da investigação. Estudos de casos selecionados são um tipo de pesquisa exploratória.

Pesquisas conclusivas. Podem ser descritivas ou causais. As descritivas, entre outras características, são utilizadas para descobrir ou verificar a existência de relação entre variáveis.

Gil (1996:45) propõe, de maneira similar à Mattar, a classificação das pesquisas com base em seus objetivos gerais. Assim, ele as classifica em três grandes grupos:

Pesquisas exploratórias. Proporcionam maior familiaridade com o problema, com vistas a torná-lo mais explícito ou a construir hipóteses. Têm como objetivo principal o aprimoramento de idéias ou a descoberta de intuições.

Pesquisas descritivas. Têm como objetivo primordial a descrição das características de uma determinada população ou fenômeno ou, então, o estabelecimento de relações entre variáveis.

Pesquisas explicativas. Têm como preocupação central identificar os fatores que determinam ou que contribuem para a ocorrência de fenômenos. É o tipo de pesquisa que mais aprofunda o 
conhecimento da realidade, porque explica a razão, o porquê das coisas.

Por outro lado, Tachizawa (2002:12) sugere três tipos, denominando-os como monografias:

> Monografia de análise teórica. Trata-se do desenvolvimento de um trabalho eminentemente conceitual, através de uma organização coerente de idéias originadas de um levantamento bibliográfico.

Monografia de estudo de caso. Procura estabelecer um roteiro prático para desenvolver uma análise específica da relação entre um caso real e modelos ou teorias.

Monografia de análise teórico-empírica. Uma análise interpretativa de dados primários em torno de um tema, com apoio bibliográfico.

\subsubsection{Tipos, Fontes e Formas de Coleta de Dados}

Segundo Mattar (1994:139), há quatro diferentes fontes básicas de dados: o pesquisado, pessoas que tenham informações sobre o pesquisado, situações similares e dados disponíveis. Com relação aos tipos de dados, o autor afirma existirem os dados primários - aqueles que não foram antes coletados, cujas fontes são as três primeiras citadas - e dados secundários - aqueles que já foram coletados.

Gil (1996:48) define ainda dois grandes grupos de delineamentos: aqueles que se valem das chamadas fontes de "papel" e aqueles cujos dados são fornecidos por pessoas. No primeiro grupo estão a pesquisa bibliográfica e a pesquisa documental. No segundo estão a pesquisa experimental, pesquisa expost-facto, o levantamento e o estudo de caso.

Quanto às formas de coleta de dados, Mattar (1994:166) afirma existirem dois meios básicos de obtenção de dados primários: a comunicação e a observação. O método da comunicação, consiste no questionamento verbal ou 
escrito. Ele compreende o uso de instrumentos de coleta de dados, que podem ser estruturados ou não estruturados.

Para caracterizar mais detalhadamente os principais métodos de coleta de dados para pesquisa, Schrader (1974:81) faz uma apresentação dos diversos métodos, considerando-se as situações de mensuração e as formas de comunicação. As situações de mensuração consideradas foram: não formalizada, formalizada mas não estruturada; formalizada e estruturada. Com as seguintes formas de comunicação: não verbal, oral, escrita.

Promovendo a combinação das diversas situações de mensuração com as diferentes formas de comunicação o autor seleciona os principais métodos de coleta de dados para pesquisa: observação, experimentação, discussão em grupo, entrevistas, análise de conteúdo.

Gil (1996:57) apresenta como principais vantagens do levantamento social o conhecimento direto da realidade, economia e rapidez, e, quantificação. As principais limitações seriam a ênfase nos aspectos perceptivos, pouca profundidade no estudo da estrutura e dos processos sociais, bem como limitada apreensão do processo de mudança. Sendo assim os levantamentos são mais apropriados para estudos descritivos do que explicativos. São úteis para o estudo de opiniões e atitudes.

\subsection{OPÇÃO METODOLÓGICA E DELINEAMENTO DA PESQUISA}

\subsubsection{Opção Metodológica}

Esta pesquisa explora quais os efeitos da estrutura organizacional na gestão do conhecimento, mais especificamente na aprendizagem organizacional. Conforme definido no capítulo 1, o objetivo principal desta pesquisa é determinar quais os efeitos dos subsistemas componentes da estrutura organizacional na geração e disseminação do conhecimento.

A preocupação central reside em fazer uma análise de como as variáveis relacionadas ao processo do conhecimento - particularmente a geração e 
disseminação - no âmbito da aprendizagem organizacional, são influenciadas pelos diversos fatores ligados aos componentes da estrutura organizacional.

Para isto há necessidade de entender como o conhecimento e as informações circulam dentro das organizações, quais tipos de conhecimento são estes, quais processos são utilizados para disseminação dos novos conhecimentos adquiridos, como são gerados os conhecimentos nas organizações, como a empresa está estruturada, dentre outros temas relevantes para o estudo.

O pesquisador precisa, para tanto, identificar como os temas da pesquisa são tratados nas organizações, correlacionando-os.

Desta maneira, enquadra-se o presente estudo como um levantamento de campo, pois se caracteriza pelo questionamento direto das pessoas cujos comportamentos ou opiniões desejamos pesquisar. Isto é feito através da coleta de informações, tratamento dos dados, análise qualitativa e elaboração das conclusões. Trata-se, portanto, de uma pesquisa qualitativa exploratória ou uma monografia de estudo de caso, conforme descrito no item 5.1.1.

Esta opção metodológica é reforçada pelo fato de existir uma lacuna na literatura em relação à correlação entre estes dois importantes temas, notadamente no Brasil. Assim, dado o estágio atual deste tipo de estudo, optamos por uma pesquisa mais profunda, que pudesse dar uma visão específica sobre as formas de algumas organizações obterem vantagens desta oportunidade.

Na definição de Yin (1994:1) os estudos de caso são a estratégia preferida quando as questões de pesquisa são, principalmente, "como" e "porque", quando o pesquisador tem pouco controle dos eventos, e quando o foco é um fenômeno contemporâneo dentro de um contexto real.

A pesquisa será desenvolvida na área de Energia, conforme descrito no item 5.5 "Critério para Seleção dos Casos e Ambiente de Pesquisa" neste mesmo capítulo. 


\subsubsection{Delineamento da Pesquisa: Roteiro}

Para Mattar (1994:22), uma forma de aprofundar o conhecimento de problemas não suficientemente definidos é através de estudos de caso selecionados.

Segundo Yin (1994:15) o estudo de caso desta pesquisa pode ser considerado exploratório pois existe ainda pouca compreensão sobre o fenômeno estudado e trata-se de uma situação na qual não existem resultados claros e únicos.

De acordo com Gil (1996:48) o delineamento refere-se ao planejamento da pesquisa em sua dimensão mais ampla, envolvendo tanto a diagramação quanto a previsão de análise e interpretação de coleta de dados. Entre outros aspectos, o delineamento considera o ambiente em que são coletados os dados e as formas de controle das variáveis envolvidas.

Para desenvolver o presente levantamento foi elaborado o seguinte roteiro:

Especificação dos objetivos e questões de pesquisa. Os objetivos e as questões de pesquisa orientaram os procedimentos metodológicos adotados neste projeto. Os objetivos e as questões de pesquisa estão detalhadamente descritos no capítulo 1 ;

> Revisão Bibliográfica: capítulos 2 a 4;

> Definição de conceitos básicos, modelos conceitual e referencial, e variáveis. Descritos nos capítulos 4 e 5;

Definição do ambiente de pesquisa e seleção da amostra. Ver item 5.5 neste capítulo;

> Definição do procedimento de coleta de dados: levantamento de fontes secundárias de dados e elaboração do instrumento de coleta de dados primários. Roteiro de entrevista conforme anexo 1 ;

Realização do levantamento de campo; 
Análise e interpretação dos dados. Ver descrição no capítulo 6;

Resultados e conclusões. Capítulo 7.

\subsection{MODELO CONCEITUAL: GESTÃO DO CONHECIMENTO}

A forma de gerenciar o conhecimento organizacional é apresentada de diversas maneiras pelos autores que abordam o tema. A partir da literatura e da experiência prática do autor foi desenvolvido o modelo conceitual descrito neste item que tem por objetivo explicar a visão do autor sobre o tema, bem como servir como base de geração de um modelo referencial para a metodologia de pesquisa. A figura abaixo apresenta de maneira esquemática o modelo conceitual desenvolvido.

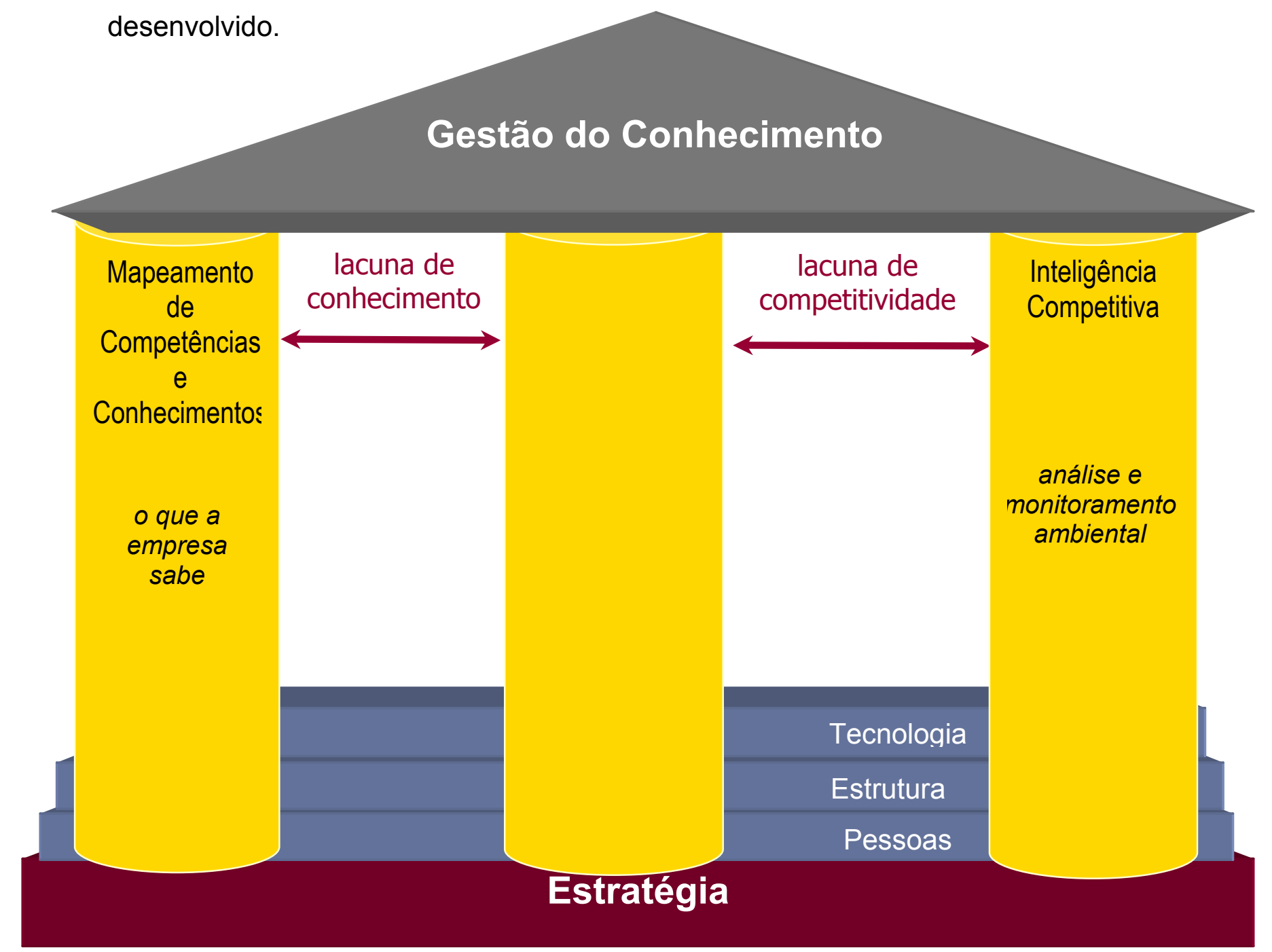

Figura 11. Modelo Conceitual de Gestão do Conhecimento

Fonte : Elaborado pelo autor 
ESTRATÉGIA DA ORGANIZAÇÃO. Toda política de gestão do conhecimento deve estar alinhada com a estratégia da organização. Ou seja, o projeto e implantação de ações voltadas à gestão do conhecimento deverão estar condizentes com o planejamento estratégico da empresa, que é a base de tudo. $\mathrm{Na}$ estratégia entendemos que está incluída a visão de mercado.

PILARES FUNDAMENTAIS. Os pilares fundamentais da gestão do conhecimento, neste modelo, são:

> Mapeamento de competências e conhecimentos. Saber o que a organização sabe.

Aprendizagem organizacional. Através da confrontação da estratégia da organização com as competências mapeadas, estabelece-se naturalmente uma lacuna de competências. A aprendizagem organizacional visa preencher esta lacuna, levando a organização a aprender aquilo que ainda não sabe, mas precisa.

> Inteligência competitiva. Analogamente, comparando-se a estratégia, com o mercado, com os concorrentes, através da análise e monitoramento ambiental, estabelece-se uma lacuna de competitividade.

Detalhes conceituais sobre os pilares podem também ser encontrados no capítulo 3.

PLANOS DE ATUAÇÃO. Os planos de atuação - baseados nas idéias contidas em Angeloni (2002) - permeiam os pilares. Significa que cada um dos conceitos embutidos nos pilares pode ser analisado sob três diferentes aspectos:

Pessoas. Este plano diz respeito às características pessoais relacionadas ao conhecimento. Para Davenport e Prusak (1998:89), as pessoas-chave do conhecimento não o possuem, meramente; elas são capazes de compartilhá-lo e desejam isto. 
> Estrutura Organizacional. Para Chiavenato (1999:663), as estruturas são as relações existentes entre os elementos componentes de uma organização. Inclui as interações, a própria configuração organizacional dos órgãos ou cargos, a hierarquia de autoridade. Inclui também cultura, processos, líderes e todos os demais conceitos vistos no capítulo 2 .

Tecnologia. Representa todos os recursos materiais, programas de computador, redes de comunicação, máquinas, equipamentos.

O CICLO DO CONHECIMENTO. Em todos os pilares e planos de atuação, bem como na intersecção deles, o conhecimento segue o ciclo de quatro fases apresentado no capítulo 3: Geração, Captura e Análise, Síntese e Arquivo, Disseminação e Uso.

\subsection{MODELO REFERENCIAL: A ESTRUTURA ORGANIZACIONAL FACILITANDO A GESTÃO DO CONHECIMENTO}

A partir do modelo conceitual descrito no item anterior estabelece-se o modelo referencial de pesquisa.

\subsubsection{Definição das Variáveis}

Em conformidade com os objetivos da pesquisa apresentados no capítulo 1 , será concentrado o foco em alguns pontos específicos do modelo conceitual. Estudar-se-á mais profundamente a intersecção entre o plano "Estrutura Organizacional" e o pilar "Aprendizagem Organizacional", mais especificamente quando o conhecimento estiver nas fases "Geração" e "Disseminação" de seu ciclo. Desta maneira, as variáveis envolvidas no modelo são: 
Variáveis independentes. São aquelas diretamente ligadas à Estrutura Organizacional, que podem ser divididas em três grupos: Grau de Formalização, Departamentalização e Atribuições. 0 interesse da pesquisa estará concentrado nos Níveis de Formalização, Critérios de Departamentalização, Atividades, Níveis de Decisão e Comunicação.

Variáveis dependentes. São aquelas referentes ao Ciclo do Conhecimento, que podem ser divididas em dois grupos: Geração e Disseminação.

Geração: forma do conhecimento entrar na organização.

- Modos de geração (segundo Davenport e Prusak, 1998:64): aquisição, grupos de trabalho, fusão, adaptação e redes de conhecimento.

- Fases da geração interna do conhecimento: geração de idéias, seleção e avaliação, estudo de viabilidade (técnica e econômica). Disseminação: transmitir conhecimento para aqueles que não possuem e precisam. Depende do tipo de conhecimento a ser disseminado:

- tácito: maior contato social;

- explícito: maior codificação.

Contexto. Todas as variáveis serão tratadas sob a ótica do pilar de Aprendizagem Organizacional.

Cultura. Para caracterizar melhor o ambiente empresarial em estudo, considera-se válido abordar - a título de subsídio complementar de análise - a cultura organizacional.

A figura seguinte representa graficamente as variáveis e o contexto envolvidos na pesquisa. 


\section{Variáveis Independentes}

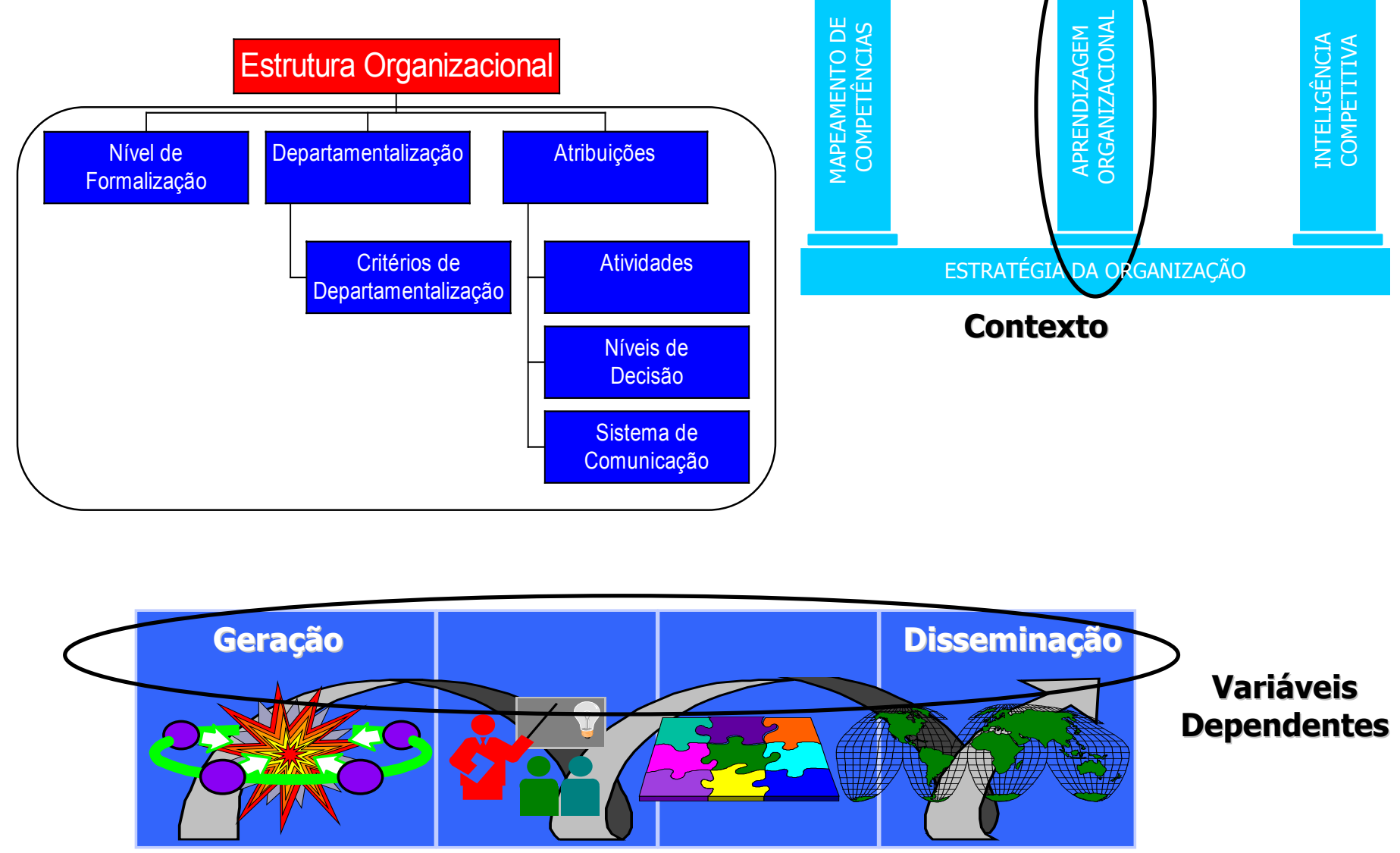

Figura 12. Modelo Referencial de Pesquisa

Fonte : Elaborado pelo autor

\subsubsection{Hipóteses}

Com o objetivo de dar diretrizes à elaboração do roteiro de pesquisa, foi realizado um exercício de determinação das hipóteses sobre os impactos esperados dos diversos componentes, em estudo, da estrutura organizacional (variáveis independentes) na geração e disseminação do conhecimento (variáveis dependentes). Processo análogo foi desenvolvido para a cultura organizacional e para o contexto.

É importante ressaltar que as hipóteses aqui apresentadas não guardam rigor estatístico. São apenas suposições, conjeturas, proposições, suspeitas sobre as influências esperadas entre variáveis. Estas hipóteses foram 
desenvolvidas de forma a motivar e facilitar a elaboração do roteiro de entrevistas e para ajudar no raciocínio durante a análise das respostas, não tendo a pretensão de serem conclusivas, passíveis de teste ou comprovação estatística.

Reconhece-se que este não é um trabalho que permitirá comprovar alguma teoria através de hipóteses e que esta metodologia carrega diversas limitações que serão apresentadas no item 7.6. As tabelas resultantes são as seguintes:

\section{Cultura Organizacional}

\begin{tabular}{|l|l|l|}
\hline & \multicolumn{1}{|c|}{ GERAÇÃO } & \multicolumn{1}{c|}{ DISSEMINAÇÃO } \\
\hline Cultura & - Quando as pessoas se & - A cultura interfere na disseminação. \\
Organizacional & $\begin{array}{l}\text { predispõem a achar soluções } \\
\text { juntas, significa que existiu no } \\
\text { passado a formação de uma } \\
\text { cultura que facilita a geração de } \\
\text { compartilhar informação, o processo } \\
\text { de disseminação do conhecimento é } \\
\text { facilitado. Por outro lado, se } \\
\text { informação é poder na empresa, a } \\
\text { - Culturas voltadas à inovação, } \\
\text { experimentação e aprendizado } \\
\text { disseminação é difícil. } \\
\text { contínuo facilitam a geração de } \\
\text { conhecimento. }\end{array}$ \\
\hline
\end{tabular}

Figura 13. Cultura Organizacional

Fonte : Elaborado pelo autor

\section{Variáveis Independentes}

\begin{tabular}{|c|c|c|}
\hline Nível de Formalização & GERAÇÃO & DISSEMINAÇÃO \\
\hline Formal & $\begin{array}{l}\text { A existência de critérios e } \\
\text { políticas formais para inovação } \\
\text { tendem a facilitar o processo } \\
\text { de geração de novos } \\
\text { conhecimentos. }\end{array}$ & $\begin{array}{l}\text { A estrutura formal fornece } \\
\text { respaldo oficial ao } \\
\text { conhecimento a ser } \\
\text { disseminado, principalmente o } \\
\text { explícito pois permite validar } \\
\text { através de mecanismos } \\
\text { reconhecidos normativamente } \\
\text { pela organização. }\end{array}$ \\
\hline Informal & $\begin{array}{l}\text { - A formação de redes de } \\
\text { relacionamento informais tende } \\
\text { a facilitar a geração do } \\
\text { conhecimento, principalmente } \\
\text { daquele multidisciplinar, que } \\
\text { depende da interação de } \\
\text { diversos departamentos e } \\
\text { especialistas. } \\
\text { - Estruturas informais tornam } \\
\text { mais rápida a geração de } \\
\text { conhecimento. }\end{array}$ & $\begin{array}{l}\text { A existência de um grau } \\
\text { relativamente alto de } \\
\text { informalidade facilita e torna } \\
\text { mais rápida a disseminação do } \\
\text { conhecimento, principalmente o } \\
\text { tácito pois facilita e estimula o } \\
\text { contato pessoal. }\end{array}$ \\
\hline
\end{tabular}

Figura 14. Nível de Formalização

Fonte : Elaborado pelo autor 


\begin{tabular}{|l|l|l|}
\hline Departamentalização & \multicolumn{1}{|c|}{ GERAÇÃO } & \multicolumn{1}{|c|}{ DISSEMINAÇÃO } \\
\hline Critérios de & - A criação de um departamento de P\&D & - A criação de função \\
Departamentalização do & e/ou de função especifica para gestão do \\
conhecimento facilita a geração do & $\begin{array}{l}\text { conhecimento facilita a } \\
\text { disseminação do }\end{array}$ \\
& $\begin{array}{l}\text { conhecimento. } \\
\text { - A geração do conhecimento é facilitada em } \\
\text { organizações que possuem estruturas mais } \\
\text { flexíveis, temporárias e autônomas, que } \\
\text { facilitem a integração interfuncional e }\end{array}$ & $\begin{array}{l}\text { - Departamentos com } \\
\text { fronteiras mais permeáveis } \\
\text { facilitam a disseminação do } \\
\text { conhecimento. }\end{array}$ \\
\hline
\end{tabular}

Figura 15. Departamentalização

Fonte : Elaborado pelo autor

\begin{tabular}{|c|c|c|}
\hline $\begin{array}{l}\text { Atribuições } \\
\text { (Distribuição de } \\
\text { Poderes) }\end{array}$ & GERAÇÃO & DISSEMINAÇÃO \\
\hline $\begin{array}{l}\text { Atividades } \\
\text { (papel do líder) }\end{array}$ & $\begin{array}{l}\text { A geração do conhecimento é } \\
\text { facilitada por um líder que } \\
\text { inspire confiança, que } \\
\text { estimule a aprendizagem } \\
\text { contínua, que saiba ouvir e } \\
\text { que seja comunicativo. }\end{array}$ & $\begin{array}{l}\text { - O compartilhamento dos resultados com os } \\
\text { colaboradores pela liderança estimula disseminação } \\
\text { futura de conhecimento. } \\
\text { - A gerência média tem papel fundamental na } \\
\text { transferência do conhecimento, tanto para baixo } \\
\text { quanto para cima. }\end{array}$ \\
\hline $\begin{array}{l}\text { Níveis de } \\
\text { Decisão }\end{array}$ & $\begin{array}{l}\text { Nas organizações onde o } \\
\text { poder de decisão está próximo } \\
\text { do conhecimento, a geração } \\
\text { de novos conhecimentos é } \\
\text { facilitada pois existe mais } \\
\text { liberdade e autonomia para } \\
\text { experimentação, com reduzida } \\
\text { ameaça de punição por erros. }\end{array}$ & $\begin{array}{l}\text { A necessidade de disseminação é reduzida em } \\
\text { organizações cujo poder de decisão está próximo do } \\
\text { conhecimento. Evitam-se inclusive os custos de } \\
\text { transferência. }\end{array}$ \\
\hline Comunicação & $\begin{array}{l}\text { - Sistemas eficazes de } \\
\text { comunicação facilitam a } \\
\text { geração de conhecimento, } \\
\text { principalmente daquele } \\
\text { multidisciplinar, que depende } \\
\text { da interação de diversos } \\
\text { departamentos e } \\
\text { especialistas. } \\
\text { - Comunidades de prática e } \\
\text { fóruns de debate facilitam a } \\
\text { geração de conhecimento. }\end{array}$ & $\begin{array}{l}\text { - Um sistema eficaz de comunicação facilita a } \\
\text { disseminação. A disseminação do conhecimento } \\
\text { explícito é facilitada pela comunicação escrita } \\
\text { (impressa ou eletrônica). A disseminação do } \\
\text { conhecimento tácito é facilitada pela comunicação } \\
\text { pessoal, principalmente lateral. } \\
\text { - Empresas com sistema de comunicação e cultura } \\
\text { voltadas para comunicação vertical percebem mais } \\
\text { dificuldade na disseminação do conhecimento. } \\
\text { - Em organizações onde o acesso à base de dados } \\
\text { é facilitada, a disseminação é mais rápida. } \\
\text { - A ampla utilização de tecnologia de comunicações } \\
\text { facilita a disseminação do conhecimento, } \\
\text { principalmente o explícito. } \\
\text { - Comunidades de prática e fóruns de debate } \\
\text { facilitam a disseminação de conhecimento. } \\
\text { - A existência de uma linguagem ou nomenclatura } \\
\text { comum facilita a disseminação de conhecimento. }\end{array}$ \\
\hline
\end{tabular}

Figura 16. Atribuições

Fonte : Elaborado pelo autor 


\section{Contexto}

\begin{tabular}{|l|l|l|}
\hline & \multicolumn{1}{|c|}{ GERAÇÃO } & \multicolumn{1}{|c|}{ DISSEMINAÇÃO } \\
\hline $\begin{array}{l}\text { Aprendizagem } \\
\text { Organizacional }\end{array}$ & $\begin{array}{l}\text { - Estímulo e investimento em } \\
\text { aprendizagem individual e coletiva } \\
\text { facilitam a geração do } \\
\text { conhecimento. } \\
\text { - Aprendizagem estimula a } \\
\text { inovação. }\end{array}$ & $\begin{array}{l}\text { A aprendizagem organizacional ocorre } \\
\text { quando se compartilha o } \\
\text { conhecimento novo. }\end{array}$ \\
\hline
\end{tabular}

Figura 17. Aprendizagem Organizacional

Fonte : Elaborado pelo autor

\subsubsection{Procedimento de Coleta de Dados}

A fase de coleta de dados do presente estudo tem duas fases distintas: 0 levantamento de dados secundários e o levantamento de dados primários.

\section{Levantamento de dados secundários}

Esta fase tem o objetivo de obter dados sobre as empresas selecionadas para compor o estudo de caso e sobre o ambiente de pesquisa.

\section{Levantamento de dados primários}

Yin (1994:78) afirma que os dados podem ser originados de seis fontes: documentação, registros em arquivos, entrevistas, observação direta, observação participante e artefatos físicos.

Segundo Yin (1994:84), o roteiro de entrevista em um estudo de caso que aplica métodos qualitativos de levantamento de dados pode ser:

Entrevista aberta, no qual se pode questionar os entrevistados por fatos do assunto, bem como solicitar opiniões sobre eventos. Em algumas situações pode-se até mesmo solicitar ao respondente que coloque a sua própria percepção sobre certas ocorrências; 
Entrevista focalizada, na qual o investigador normalmente segue um certo conjunto de questões prévias, nestes casos as entrevistas podem ainda ser abertas e assumir uma forma de conversação;

Entrevista estruturada, com questões conduzidas com levantamento formal e sem flexibilidade para alterações.

Com o objetivo de um maior aprofundamento e entendimento das variáveis da Estrutura Organizacional que influenciam a Gestão do Conhecimento, serão utilizadas como fontes primárias de obtenção de dados as entrevistas individuais focalizadas, realizadas pelo próprio autor, guiadas por um roteiro de entrevista.

O roteiro de entrevista foi elaborado com base no modelo referencial apresentado no item 5.4.1. O modelo do roteiro de pesquisa encontra-se no anexo 1.

Este roteiro não foi utilizado rigidamente. Serviu como um direcionador da conversa com o entrevistado. As questões foram colocadas para discussão na medida em que os temas foram tratados e desenvolvidos, não necessariamente na ordem em que elas aparecem no roteiro. Se ao responder uma questão o entrevistado abordou um tema que não era o seguinte, a fluidez da conversa não foi prejudicada em detrimento da seqüência previamente estabelecida para as questões. De modo que ao final de cada entrevista todas as questões haviam sido discutidas.

Uma parcela significativa do roteiro de entrevista foi adaptada de Terra, 1999.

As entrevistas foram realizadas entre fevereiro e abril de 2004 e estão gravadas em fita cassete de forma a preservar a fidedignidade das respostas e facilitar a análise. 


\subsubsection{Análise de Dados}

Yin (1994:103) propõe duas formas de análise de dados em um estudo de caso:

Reflexão sobre o conjunto das questões de pesquisa, revisão da literatura e novas descobertas de pesquisa, originadas a partir das proposições teóricas. Estas proposições orientam a coleta e análise de dados e contribuem para o entendimento da realidade, permitindo a análise partir de um referencial teórico estabelecido;

Elaboração de um referencial descritivo voltado à empresa em estudo, onde o pesquisador objetiva apenas descrever a realidade ou quando não há proposição teórica.

A primeira forma mostra-se mais adequada à presente pesquisa pois o autor propôs um modelo conceitual teórico que foi a base do modelo referencial da pesquisa.

Com os dados gerais obtidos através da aplicação das entrevistas, foi elaborada uma análise qualitativa para detecção de correlação efetiva entre questões e variáveis, de modo a ser possível detalhar análises e conclusões finais.

\subsection{CRITÉRIO PARA SELEÇÃO DOS CASOS E AMBIENTE DE PESQUISA}

Uma questão importante a ser considerada é a área de abrangência da pesquisa. Não faria sentido fazer uma pesquisa geral - cobrindo diversos segmentos da economia - pois existe uma clara distinção de como este setores tratam o problema do conhecimento e da estrutura organizacional.

Mesmo dentro de um só setor podem coexistir empresas de diversas naturezas - estatais, privadas, nacionais, multinacionais, industriais, de serviços que devido aos seus objetivos particulares eventualmente podem atuar de 
maneira muito variada e encarar o problema apresentado de maneira significativamente diferente, apresentando as mais variadas soluções.

Sendo assim, optou-se por estudar um só setor da economia e dentro dele dar maior ênfase a alguns determinados tipos de empresas.

Esta pesquisa foi desenvolvida no setor energético, que envolve empresas do mercado de gás, da indústria do petróleo, bem como geradoras, transmissoras e distribuidoras de energia elétrica, além de fornecedores de produtos e serviços para estes mercados.

O interesse pelo ramo de energia justifica-se pelo fato da sociedade brasileira estar novamente discutindo a necessidade de investimentos nesta área como forma de garantia de sustentação da fase de crescente desenvolvimento que se prenuncia. E a energia, como insumo básico da imensa maioria dos processos, representa papel de capital importância.

Para esta nova fase, empresas que atuam no Brasil neste setor precisam preparar suas estruturas para gerar novos conhecimentos que lhes garantam a competitividade necessária.

Dentre as diversas empresas atuantes neste setor, a área de principal interesse será a das organizações que atuam no fornecimento ou aquisição de soluções, equipamentos ou serviços para usinas hidrelétricas. 


\section{CAPÍtULO 6}

\section{Análise e Interpretação}

dos Dados

"O maior obstáculo ao progresso não é a ignorância e sim a ilusão do conhecimento." 


\section{CAPÍTULO 6: Análise e Interpretação dos Dados}

\subsection{INTRODUÇÃO}

Neste capítulo descreve-se a pesquisa de campo realizada, desde a escolha das empresas até a apresentação, análise e interpretação dos dados coletados.

Conforme detalhado no capítulo 5 , esta pesquisa foi desenvolvida no setor energético, que envolve empresas do mercado de gás, da indústria do petróleo, bem como geradoras, transmissoras e distribuidoras de energia elétrica, além de fornecedores de produtos e serviços para estes mercados. Dentre as diversas empresas atuantes neste setor, a área de principal interesse será a das organizações que atuam no fornecimento ou aquisição de soluções, equipamentos ou serviços para usinas hidrelétricas.

\subsection{O SETOR: ENERGIA}

Segundo Canola (2002:20) o Plano Decenal 1999/2008 da Eletrobrás aponta para o alto crescimento do consumo de energia elétrica, por questões de demanda reprimida, e aponta ainda para a necessidade de expansão do parque de geração visando o atendimento da demanda e a disponibilização de meios para permitir o desenvolvimento necessário à superação da pobreza e do subdesenvolvimento. O planejamento governamental prevê a necessidade de investimentos da ordem de $\mathrm{R} \$ 6$ a 7 bilhões ao ano para expansão da matriz energética brasileira.

A energia consumida por habitante/ano é um indicador do nível de desenvolvimento de um país, juntamente com o PIB, renda per capta, analfabetismo, entre outros. 
Canola (2002:22) salienta ainda que historicamente, até 1975, os investimentos no setor energético brasileiro representavam cerca de 8 a $10 \%$ dos investimentos totais do governo. A política de redução da dependência externa e o aumento da demanda passaram a exigir maiores investimentos em energia. $O$ ápice ocorreu em 1984, quando os investimentos em energia representavam $24 \%$ do total. Hoje esta porcentagem voltou ao nível de 1975.

A década de 1980 foi um período bastante fértil para a engenharia nacional na área de energia. Devido aos altos investimentos citados, as empresas desenvolveram e capacitaram profissionais das mais diversas disciplinas. Mais do que isto, capacitaram equipes e o Brasil atingiu um excelente nível técnico em diversos setores do complexo energético, como por exemplo prospecção de petróleo e construção de hidrelétricas.

Com a redução dos investimentos ocorrida na década seguinte, estas equipes de alta performance foram desmobilizadas e muito deste conhecimento foi perdido. Não somente o conhecimento do produto mas também o conhecimento do processo de trabalho. O qual, muitas vezes, é ainda mais difícil de recuperar.

O mercado energético está vivendo um período de mudanças fundamentais: privatização, desregulamentação, abertura de mercados, forte concorrência.

Produtores e distribuidores de energia estão constantemente buscando formas de reduzir os custos operacionais e, por isso, demandam soluções inovadoras.

Os investidores tradicionais eram as grandes estatais da área elétrica nacional, como ELETRONORTE, CHESF e CESP, por exemplo. Estes clientes sabiam muito bem o que estavam comprando, preparavam editais $\mathrm{e}$ especificações bem detalhadas. Os fornecedores eram tratados igualmente e a compra era decidida pelo preço. Os prazos normalmente eram longos. 
Após a abertura do mercado para investidores privados, o cenário mudou. Os clientes agora são grandes investidores ou mega-empresas com grande consumo de energia, tais como VOTORANTIM, BELGO-MINEIRA, entre outras. Estes clientes já não sabem com detalhes o que estão comprando. Interessa-lhes principalmente de onde virá o dinheiro, qual o retorno do investimento e quando será gerada a energia.

Sendo que são clientes privados, estão dispostos até a pagar um pouco mais por um produto que ofereça uma relação custo/benefício mais atrativa. Os prazos são muito curtos.

Anteriormente os clientes compravam equipamentos, tais como geradores e turbinas, para usinas hidrelétricas que eles mesmos estavam construindo e iriam operar futuramente. Sendo assim os contratos de fornecimento eram focados no produto e o seu conceito, via de regra, já estava inteiramente descrito em detalhadas especificações.

Atualmente, como os clientes não são do ramo, eles compram soluções. São os contratos do tipo "turn-key". O cliente aparece para fechar o contrato e cobrar o cumprimento dos prazos através de pesadas multas. Não existe grande envolvimento técnico ao longo do processo.

Para gerenciar todas estas mudanças, os clientes querem respostas rápidas e alinhadas. Eles estão procurando fornecedores que possam responsabilizar-se por tudo. O chamado "one-stop shopping”. Da simples compra de componentes até um sofisticado atendimento de serviços; de sistemas novos, tipo "turn-key" até a modernização completa de velhas usinas. Eles querem um parceiro que possa oferecer localmente uma experiência global.

Face ao eminente desenvolvimento do setor, que se encontra estagnado desde 2002, empresas que atuam no Brasil precisam preparar suas estruturas para gerar novos conhecimentos que Ihes garantam a competitividade necessária. 


\subsection{AS EMPRESAS}

Dentro do contexto descrito no item anterior, e focando no mercado de geração, transmissão e distribuição de energia elétrica, é possível visualizar dois grandes grupos de empresas: as investidoras e as provedoras de soluções.

As empresas investidoras são aquelas que decidiram explorar a área de produção, distribuição e venda de energia como sua atividade principal. Seja para fornecer energia para o consumidor final ou para consumo próprio, neste caso são denominados autoprodutores.

Até é possível encontrar provedores completos de solução, mas normalmente são necessárias duas grandes especialidades que, via de regra, se consorciam para fornecer a solução para um investidor. São elas: obra civil e equipamentos eletro-mecânicos.

Seguindo este raciocínio, foram escolhidas três empresas para compor a pesquisa, cada uma representando um dos grupos citados:

\section{Investidor: AES Eletropaulo}

Fornecedor da solução civil: Camargo Corrêa

Fornecedor da solução eletro-mecânica: Siemens

É salutar salientar que, dentro deste contexto, foram escolhidas empresas onde o autor mantinha contatos profissionais ou pessoais. Este fato confere melhoria nas possibilidades de pesquisar mais profundamente com elevado grau de confiabilidade, devido à relação entre entrevistado e entrevistador não ter iniciado com este trabalho e também pelo fato do autor não ser uma pessoa completamente estranha às empresas.

O fato das empresas e do setor já serem de conhecimento prévio do autor permite que, em menos tempo, retire-se mais informações pois o contexto é conhecido e vai-se mais diretamente ao cerne das questões. 
Neste item apresentaremos as três empresas, descrevendo-as a partir de dados secundários confirmados ou complementados nas visitas e entrevistas.

\subsubsection{AES Eletropaulo}

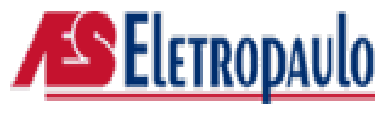

A AES é uma empresa global, líder na área de energia, com faturamento de US\$ 8.4 bilhões em 2003. Fornece 45 megawatts de potência elétrica para 11 milhões de consumidores finais em 27 países, através de 116 usinas e 17 empresas de distribuição. A AES tem cerca de 30.000 colaboradores mundialmente e um ativo aproximado de US $\$ 30$ bilhões.

O objetivo da empresa é ajudar a alcançar as necessidades mundiais de energia elétrica em uma forma que beneficie todas as partes interessadas enquanto agrega valor de longo prazo aos seus acionistas.

A AES é composta de unidades de negócios que servem as mais diversas regiões geográficas do mundo e cada grupo é responsável por todas as atividades do negócio na sua região, incluindo operação, construção e desenvolvimento de novos negócios.

Cultura Corporativa. O núcleo da cultura da AES é o comprometimento de todo seu pessoal com os valores compartilhados:

Integridade. As pessoas na AES empenham-se em atuar com integridade.

> Honestidade. As pessoas na AES pretendem lidar honestamente com o próprio pessoal interno, bem como com seus clientes, fornecedores, acionistas, governo e comunidades onde a AES opera.

Responsabilidade Social. As pessoas na AES empenham-se em agir em todos os casos com responsabilidade social e acreditam que trabalhar para atingir a missão da AES é a sua primeira responsabilidade social na AES. 
Divertimento. As pessoas na AES desejam que seus colegas de trabalho e aqueles com os quais eles interagem divirtam-se no trabalho, no sentido em que se empenhando para atingir um alto grau de performance, sendo confiado para decidir para atingir esta performance, e sendo apoiado responsavelmente em decisões, é divertimento.

Segundo Graham e Pizzo (2002:20) os valores da AES são centrais para avaliação de empregados em perspectiva e constituem o conteúdo dos programas de treinamento de novos empregados. Medições dos desempenhos corporativo e individual que verificam a aderência a valores são tão importantes quanto às medições financeiras. Enquanto muitas empresas estão tentando delegar funções centralizadas de assessoria (como recursos humanos, finanças) para linha, a AES jamais centralizou estas funções. Ao invés disto, as equipes multidisciplinares de projetos de instalações geradoras dirigem as operações e cuidam de todas as tarefas de apoio.

Esses autores enfatizam ainda (2002:21) que na AES todas as instalações são organizadas em "famílias" compostas de 10 a 20 pessoas que se autogerenciam e se autolideram. Forças-tarefa estão em toda parte; incluem equipes transempresas, intra-unidade e interunidades. Algumas são temporárias e abordam questões especificas e outras são permanentes. De forma generalizada, a gerência baseada em equipe e a ênfase em responsabilidade na linha de frente difundidas em toda a empresa eliminaram grande parte da hierarquia formal da AES.

\section{AES Eletropaulo - Brasil}

A AES Eletropaulo é a subsidiária brasileira da AES e a maior distribuidora de energia elétrica da América Latina.

A AES Eletropaulo distribui energia elétrica em 24 municípios da Grande São Paulo, incluindo a capital. Nesta área, a empresa atende mais de 16 milhões de pessoas, concentradas em cinco milhões de unidades consumidoras. No 
principal centro econômico do Brasil, o consumo anual aproximado é de 32,5 mil gigawatts-hora de energia.

A empresa conta com cerca de quatro mil funcionários. Entre seus ativos estão 132 estações transformadoras de distribuição (ETD), totalizando 12,6 GVA de potência instalada, 1,7 mil km de circuito de subtransmissão (138/88 kV) e uma rede de aproximadamente $311 \mathrm{mil} \mathrm{km}$ de condutores aéreos, $10 \mathrm{mil} \mathrm{km} \mathrm{de}$ condutores subterrâneos e 1,2 milhão de postes. Esta estrutura está espalhada pelos $4.526 \mathrm{~km}^{2}$ da área de concessão da empresa, que concentra o maior PIB per capita do Brasil.

O controle acionário da empresa é da AES Corporation. A Eletropaulo foi privatizada em 15 abril de 1998 por um grupo de empresas que incluíam, além da AES, a Companhia Siderúrgica Nacional (CSN), a Eletricité de France (EDF) e a Reliant Energy. Em 2001, a AES, uma das maiores companhias de energia do mundo, tornou-se o acionista controlador da empresa.

A atual infra-estrutura de operação e atendimento da AES Eletropaulo foi planejada e montada para responder a um mercado muito dinâmico e exigente, com um parque industrial diversificado, com uma rede de comércio e serviços similar a qualquer outra metrópole mundial numa região densamente povoada.

A diretoria da empresa é dividida em sete vice-presidências que traçam as diretrizes para melhorar a qualidade dos serviços prestados e ampliar a rede de atendimento com toda a segurança.

O corpo administrativo da empresa responde por todas as necessidades da área operacional, dando o apoio necessário para uma operação que garante a qualidade da energia elétrica no principal pólo econômico do Brasil.

\section{História}

A Eletropaulo - Eletricidade de São Paulo S.A. tem suas origens em 7 de abril de 1899 com a fundação da The São Paulo Tramway, Light and Power Co. Ltda., em Toronto, no Canadá. 
Em 17 de julho do mesmo ano, a empresa foi autorizada, por decreto do presidente Campos Salles, a atuar no Brasil.

A partir de então sua história se confundiu com o desenvolvimento da capital do Estado de São Paulo.

Em 1904, o grupo fundou a The Rio de Janeiro Tramway, Light and Power Co. Ltda. e estendeu seu mercado à capital da República. A partir de 1912, as empresas passaram a ser controladas pela holding Brazilian Traction Light and Power Co. Ltda.

Em 1956, o grupo reestruturou-se tendo por base a Brascan Limited. Em 1979, o governo brasileiro, por meio da Eletrobrás, adquiriu da Brascan o controle acionário da então Light-Serviços de Eletricidade S.A.

Em 1981, o Governo do Estado de São Paulo adquiriu da Eletrobrás o subsistema paulista da Light, criando a Eletropaulo - Eletricidade de São Paulo S.A.

Com o programa de privatização lançado pelo governo em 1995, a Eletropaulo foi reestruturada em 31 de dezembro de 1997, dando origem a quatro empresas: Eletropaulo Metropolitana - Eletricidade de São Paulo S.A.; EBE Empresa Bandeirante de Energia S.A.; EPTE - Empresa Paulista de Transmissão de Energia Elétrica S.A. e a Emae - Empresa Metropolitana de Águas e Energia S.A.

Com a cisão, coube à Eletropaulo Metropolitana - Eletricidade de São Paulo S.A. a distribuição de energia elétrica em 24 municípios da Grande São Paulo, onde vivem mais de 16 milhões de pessoas. Em 15 de abril de 1998, foi adquirida em leilão pela Lightgás, subsidiária do grupo Light, formado pelas empresas americanas AES Corporation, Houston Industries Energy, Inc.(a atual Reliant Energy), pela francesa Electricité de France (EDF) e pela brasileira Companhia Siderúrgica Nacional (CSN). 
Em 2001, com a venda das ações da Reliant e da CSN, a Eletropaulo passou a ser controlada pela AES, marcando um novo tempo na história da empresa.

\subsubsection{Camargo Corrêa}

Com 16 empresas e cerca de 35 mil funcionários, o Grupo Camargo Corrêa é hoje uma das maiores corporações privadas do país. Começou com uma construtora, em 1939, e avançou para muitas outras áreas. Diversificado, o Grupo tira o máximo da sinergia entre suas empresas, para oferecer produtos e soluções.

Engenharia, produção de cimento, tecidos, calçados, siderurgia e metalurgia, meio ambiente, serviços na área de rodovias, geração e distribuição de energia elétrica - são muitas as frentes de ação, produtos e soluções oferecidos pelo Grupo.

Controladas pela holding Camargo Corrêa S.A., em 2002 os investimentos consolidados alcançaram $\mathrm{R} \$ 688,1$ milhões com recursos próprios e o faturamento, $\mathrm{R} \$ 6,2$ bilhões.

\section{História}

Jaú, interior de São Paulo, 1909. Nessa vila, cercada de fazendas de café e ligada à capital pela ferrovia, nasceu Sebastião Camargo, o fundador daquele que se tornaria um dos maiores conglomerados empresarias do Brasil. Audacioso, inovador, Sebastião Camargo começou a trilhar sua história de trabalho logo cedo. Aos 17 anos, transportava terra numa carrocinha puxada a burro. Outras carroças vieram e terra e pedras seguiam para aterros e estradas. Logo, Sebastião deixou de ser autônomo para ser sub-empreiteiro. 
Em 1939, Sebastião Camargo encontra o advogado Sylvio Brand Corrêa juntos eles fundaram uma pequena construtora, a Camargo Corrêa \& Cia. Ltda. Engenheiros e Construtores.

Na década de 1950 o Grupo destacou-se na construção das primeiras grandes usinas hidrelétricas e rodovias na região da nova capital do país, Brasília, além de prosseguir na trajetória de diversificação de seus investimentos. Em 1956 ocorre a construção da Usina Hidrelétrica Euclides da Cunha (SP), primeira empreitada da Camargo Corrêa no setor.

No decênio dos 1960, a Camargo Corrêa construiu novas usinas hidrelétricas de grande porte, que representaram um passo decisivo para o desenvolvimento do know-how brasileiro no setor, proporcionando a energia necessária para o abastecimento dos grandes centros urbanos do país e para as diversas atividades econômicas.

Em 1975, inicia participação no consórcio internacional encarregado da construção da Usina Hidrelétrica de Itaipu, no rio Paraná, com 12.600 MW de potência, em colaboração com o Paraguai. Na inauguração da $18^{\mathrm{a}}$ unidade geradora, em 1991, a usina era a maior do mundo e representava $25 \%$ da potência instalada no Brasil.

Nos anos 1990, a Camargo Corrêa saiu em busca de parceiros para novos empreendimentos, acentuando seu processo interno de expansão e diversificação dos negócios. Depois da criação da holding Camargo Corrêa S.A., em 1996, o grupo aproveitou as oportunidades na privatização dos setores de energia elétrica e concessão rodoviária, posicionou-se bem na indústria de cimento e preparou-se para a oferta de soluções integradas em engenharia e construção (E\&C), firmando-se como conglomerado empresarial diversificado.

A partir de 2000, o grupo intensifica a estratégia de integração das empresas para aproveitar as competências e conhecimentos em cada área e oferecer soluções abrangentes e tecnologicamente inovadoras, bem como para otimizar custos. Uma revisão no direcionamento estratégico, em 2002, definiu 
como meta estar entre os primeiros grupos privados não financeiros de capital nacional do país até 2012. Decidiu ainda concentrar atuação em quatro a seis negócios-chave, em segmentos com perfis de risco e retorno distintos para se proteger contra as flutuações da economia. Em 2001 cria o Neogera - programa de computador para gerenciamento de documentos - em associação com a Promon, com o objetivo de desenvolver soluções para arquitetura, engenharia e construção, mediante o uso de ferramentas e recursos da internet. Em 2003, é implantado o sistema de Gestão de Conhecimento no Grupo Camargo Corrêa.

\section{Camargo Corrêa SA - Holding}

Holding operacional, a Camargo Corrêa S.A. (CCSA) foi criada em 1996 e deu grande impulso à integração e ao crescimento do Grupo, com aumento da sinergia entre as unidades de negócios e, conseqüentemente, da produtividade. Com a holding, o grupo aproveitou oportunidades na privatização, entrou nos mercados de geração e distribuição de energia elétrica e de concessões rodoviárias e ampliou sua presença em setores como calçados e têxteis, seguindo a estratégia de diversificar para diluir os riscos das flutuações da economia. De 1996 a 2002, a receita do grupo aumentou $211,7 \%$, de $R \$ 1.987$ milhões para $R \$$ 6.192 milhões.

Um bom exemplo da ênfase na integração é o modelo de contratação "Engineering, Procurement and Construction (EPC)", para o qual o Grupo está totalmente habilitado e pelo qual responde por todas as fases de um empreendimento projeto, compra de equipamentos, construção e montagem. As empresas da área de engenharia e construção desenvolveram competências para gerenciar todas as etapas da construção de termelétricas, hidrelétricas, subestações, edificações e plantas industriais.

Criado em 1999, o Centro de Serviços Compartilhados do Grupo Camargo Corrêa (CSC) presta serviços para as unidades de negócios como suprimentos, contabilidade, tesouraria, administração de pessoal, seguros, saúde e tecnologia da informação. 


\section{Camargo Corrêa Energia S.A.}

A Camargo Corrêa Energia é uma empresa voltada à administração de negócios de geração e distribuição de energia elétrica. Por meio dela, o grupo participa da VBC, maior investidor privado no setor elétrico brasileiro, e desenvolve projetos de geração de energia.

Criada em maio de 2002, a Camargo Corrêa Energia faz parte do processo de reestruturação dos negócios na área de energia, de importância crescente no portfólio de investimentos do Grupo. A companhia administra negócios de geração e distribuição de energia elétrica e tem 33,3\% da VBC Participações - os outros sócios são o Grupo Votorantim e a Bradespar.

Além de gerenciar os investimentos na CPFL Energia - da qual a VBC detém $45,3 \%$ do capital - a empresa tem como objetivo coordenar as participações diretas em empreendimentos voltados à geração de energia, visando garantir o suprimento às diversas unidades do Grupo Camargo Corrêa.

A Camargo Corrêa Energia registra avanços importantes no programa de autoprodução. Além da hidrelétrica de Machadinho, que tem a Camargo Corrêa Cimentos entre seus investidores, o Grupo venceu, em parceria, leilões para a construção de outras usinas.Todas elas, mais a PCH Camargo Corrêa, na Fazenda Arrossensal, sob gerenciamento da Camargo Corrêa Energia, vão fornecer energia para as empresas do Grupo. Os negócios controlados pela Camargo Corrêa Energia produziram receita bruta de R\$1.087 milhões em 2002.

Através da Camargo Corrêa Energia e Camargo Corrêa Construções o grupo é, ao mesmo tempo, investidor e provedor de soluções civis.

\section{Visão}

"Seremos reconhecidos como líderes por nossos padrões éticos, competência empresarial, excelência de produtos e serviços, respeito ao ambiente e à comunidade, atuando de modo integrado em infra-estrutura, indústria, engenharia e construção." 


\section{Valores}

As atividades do Grupo baseiam-se em sólidos valores corporativos:

Criação de Valor: compromisso permanente com clientes, acionistas e sociedade.

Ética e Integridade: ações desenvolvidas com ética, profissionalismo e responsabilidade social e ambiental.

Pessoas: diferencial competitivo.

Estratégia: o caminho para a construção do futuro almejado.

Inovação: busca constante do novo, visando aprimorar a geração de valor.

\subsubsection{Siemens}

A SIEMENS é uma empresa transnacional de origem alemã, com presença em 190 países, que atua no setor eletro-eletrônico.

O faturamento no ano comercial 2003 foi de 74,2 bilhões de euros quando seu quadro de pessoal alcançou a marca de 417 mil colaboradores. investimento em pesquisa e desenvolvimento neste mesmo ano foi de 5 bilhões de euros, empregando 56000 pessoas. O investimento em treinamento foi de 500 milhões de euros. Cerca de $68 \%$ dos colaboradores têm qualificação profissional e 34\% têm diploma universitário.

\section{A Siemens no Brasil}

A Siemens está fortemente representada no Brasil. As primeiras atividades da empresa no país datam de 1867, com a instalação da linha telegráfica pioneira entre o Rio de Janeiro e o Rio Grande do Sul. Em 1895, no Rio de Janeiro, era aberto o primeiro escritório e, dez anos mais tarde, ocorria a fundação da 
empresa no Brasil. A Siemens é uma das empresas líderes do mercado eletroeletrônico brasileiro, com atividades nos segmentos de negócios Informação e Comunicação, Automação e Controle, Médico, Energia, Transporte e lluminação.

No Brasil, o grupo conta hoje com 7.236 colaboradores e doze unidades fabris, algumas ocupando lugar de destaque na organização mundial, como a fábrica de Manaus, um dos três centros de competência mundiais da Siemens para a fabricação dos telefones celulares GSM. O faturamento líquido foi de R\$ 4,6 bi, resultando em um lucro líquido de $\mathrm{R} \$ 174,8$ milhões.

\section{Princípios}

Os princípios da empresa proporcionam aos colaboradores conceitos para pensar e agir de forma empreendedora. Eles estabelecem uma base para uma mudança cultural e indicam o esforço que é esperado de cada um dos colaboradores na direção da melhoria contínua. Os "Nossos Princípios" surgiram de um estudo amplo, conduzido de forma a determinar os valores que os próprios colaboradores consideravam importantes e essenciais, o que os incentivava e os levava ao êxito. Baseado no resultado desta ampla pesquisa, feita com colaboradores de todo o mundo, foram desenvolvidos os Cinco Princípios:

Fortalecemos nossos CLIENTES - para mantê-los competitivos. Nosso sucesso depende do sucesso de nossos clientes. Fornecemos vasta experiência e soluções abrangentes para que eles possam alcançar seus objetivos com mais rapidez e efetividade.

Impulsionamos a INOVAÇÃO - para moldar o futuro. A inovação é nosso fluido vital, em todo o mundo e a todo o momento. Transformamos a imaginação e as melhores práticas de nossos colaboradores em tecnologias e produtos de sucesso. A criatividade e a experiência nos mantêm na vanguarda.

Aumentamos o VALOR da empresa - para dar origem a novas oportunidades. Geramos crescimento lucrativo para garantir sucesso sustentável. 
Alavancamos nosso portifólio equilibrado de negócios, nossa excelência empresarial e as sinergias em todos os segmentos e regiões. Isso nos torna um investimento especialmente atrativo para nossos acionistas.

Concedemos autonomia aos nossos COLABORADORES - para atingir desempenho de classe mundial. Nossos colaboradores são a chave do nosso sucesso. Eles trabalham em conjunto, como uma rede global de conhecimento e aprendizado. Nossa cultura é definida pela diversidade, pelo diálogo aberto e respeito mútuo, bem como por objetivos claros e liderança eficaz.

Adotamos a RESPONSABILIDADE empresarial - para o desenvolvimento da sociedade. Nossas idéias, tecnologias e atividades ajudam a criar um mundo melhor. Estamos comprometidos com valores universais, boa cidadania empresarial e com um ambiente saudável. A integridade orienta nossa conduta perante nossos colaboradores, parceiros de negócios e acionistas.

\section{História}

Fundada em 1847, a empresa de negócios telegráficos Siemens \& Halske cresceu no espaço de poucas décadas de uma fábrica pequena de engenharia de precisão para uma das maiores empresas do ramo de eletro-eletrônicos. Quando Werner von Siemens descobriu o princípio do dínamo, a aplicação potencial da energia era limitada.

Em 1879, Siemens \& Halske apresentaram a primeira estrada de ferro elétrica e instalaram a primeira iluminação elétrica de ruas em Berlin; em 1880 veio o primeiro elevador elétrico e em 1881, o carro elétrico. As inovações continuaram com iluminação, engenharia médica, comunicação sem fio e, após a segunda guerra mundial, sistemas de processamento de dados, sistemas automotivos e semicondutores.

Para dar à empresa uma identidade mais forte e uma consistente presença no mercado, Siemens \& Halske, Siemens-Schuckertwerke AG e SiemensReiniger-Werke AG, as três maiores unidades do grupo formaram em 1966 a 
Siemens AG. Em 1969, os principais segmentos de negócios da empresa foram seis unidades de negócios, criando uma estrutura organizacional que foi adaptada em numerosas ocasiões até o presente.

\subsection{OS DADOS COLETADOS}

Conforme previsto no Capítulo 5, com o objetivo de um maior aprofundamento e entendimento das variáveis da Estrutura Organizacional que influenciam a Gestão do Conhecimento, foram utilizadas como fontes primárias de obtenção de dados entrevistas individuais focalizadas, realizadas pelo próprio autor, guiadas por um roteiro de entrevista, baseado em modelo referencial, cuja íntegra encontra-se no anexo 1.

Foram realizadas 9 entrevistas no total. Optou-se por uma quantidade relativamente pequena de entrevistas para que pudessem ser tratadas com mais profundidade. Dado o caráter exploratório do estudo, acredita-se que a quantidade de contatos tenha sido suficiente para atingir o objetivo planejado. $\mathrm{O}$ fato de algumas entrevistas terem recolhido diversas informações repetidas em relação à primeira confirma esta afirmação. Além dos depoimentos dos entrevistados, foram reunidos documentos, publicações, páginas da internet e relatórios das empresas para composição dos dados secundários.

Neste tópico são apresentados e interpretados os dados coletados divididos em dados dos entrevistados, cultura organizacional, estrutura organizacional e aprendizagem. Os dados detalhados das empresas já foram apresentados no item 6.3. 


\subsubsection{Dados dos entrevistados}

Os 9 entrevistados estão divididos da seguinte forma:

\begin{tabular}{|c|c|c|c|c|c|c|c|}
\hline \multicolumn{2}{|c|}{ Empresa } & \multicolumn{2}{|c|}{ Área de Trabalho } & \multicolumn{2}{|c|}{$\begin{array}{c}\text { Experiência } \\
\text { Profissional } \\
\text { (anos) }\end{array}$} & \multicolumn{2}{|c|}{ Cargo } \\
\hline AES & 3 & $\mathrm{RH}$ & 3 & 3 a 5 & 1 & $\begin{array}{l}\text { Gerência / } \\
\text { Nível } \\
\text { Médio }\end{array}$ & 7 \\
\hline $\begin{array}{l}\text { Camargo } \\
\text { Corrêa }\end{array}$ & 2 & Marketing & 1 & 11 a 20 & 5 & Diretoria & 2 \\
\hline Siemens & 4 & Informática & 2 & $>20$ & 3 & & \\
\hline & & \begin{tabular}{|l} 
Engenharia \\
Planejamento \\
Estratégico
\end{tabular} & 2 & & & & \\
\hline
\end{tabular}

Figura 18. Dados dos Entrevistados

Fonte : Elaborado pelo autor

\subsubsection{Cultura Organizacional}

\section{SIEMENS}

Existe uma cultura de aprendizagem e colaboração na Siemens, que está inclusive nos princípios da empresa. Um dos princípios afirma serem os colaboradores a chave para o sucesso da organização e que agem em conjunto, como uma rede global de aprendizagem. Um dos pontos fracos estaria na liderança, pautada por uma estrutura hierárquica. Esta liderança poderia atrapalhar, às vezes, a criação de redes dinâmicas de conhecimento: redes que se formam temporariamente para resolver um problema complexo. 
Entretanto a empresa tem uma cultura muito forte para trabalho em equipe e utilização de estrutura matricial combinando os grupos multidisciplinares e o organograma funcional.

A Siemens sempre foi uma empresa tecnológica e, recentemente, foi fortemente influenciada pela privatização em diversas áreas, como energia e telecomunicações. Muitas pessoas têm conhecimento, são valorizadas e conseguem compartilhar.

\section{CAMARGO CORREAA}

Existe uma cultura de aprendizagem, criação e compartilhamento do conhecimento, principalmente voltada às melhores práticas. $\mathrm{O}$ conhecimento é valorizado e a informação é importante. Porém alguns profissionais com muito tempo de casa ainda seguem a linha do conhecimento é poder e o guardam por acreditar que é isto que os mantém na empresa. Está sendo feito um trabalho visando uma mudança de comportamento. O foco maior é o nível técnico e operacional, pois existe a tendência deles não serem reconhecidos como fonte de conhecimento. Há forte convicção que um patamar de estabilidade será atingido quando este conhecimento que está sendo registrado hoje passar a ser utilizado.

\section{AES ELETROPAULO}

No fim do século XIX até a estatização em 1979 teve uma cultura ortodoxa, tradicional. Até 1998 permaneceu estatal, burocrática. O conhecimento era rígido e bem delimitado por normas e padrões. Isto fazia com que a empresa fosse lenta. Após a privatização passou por 2 momentos: no primeiro, eram 4 sócios e a AES ficou com a área financeira. A estrutura manteve-se tradicional onde a Gestão do Conhecimento era caracterizada pelos nichos de especialização, não tinha a cultura de migrar o conhecimento para toda a organização. Havia pouco compartilhamento.

A História da AES Eletropaulo mudou muito nos últimos 3 anos e meio e isto influenciou fortemente a cultura. No fim de 2000 a AES tornou-se a única 
dona e implantou uma cultura completamente diferente que do ponto de vista formal foi um desastre, mas foi fantástica para alavancar o conhecimento das pessoas. Ela acabou com as áreas centralizadas, dividindo a empresa em 15 Unidades de Negócios, que eram totalmente independentes, cada com cerca de 250 colaboradores, 400.000 consumidores e todos os processos para cuidar. Isto gerou um caos, mas como cada Unidade de Negócio era pequena, as pessoas passaram a interagir mais e aprender o que os outros faziam. As pessoas passaram a entender do negócio. Isto aconteceu pois a AES tinha uma experiência muito grande em geração de energia, onde as pessoas são divididas em plantas de geração com grandes distâncias geográficas entre elas e para operar elas devem ter grande autonomia de decisão. Mas para a AES Eletropaulo que também faz distribuição para um enorme centro consumidor, não era uma estrutura adequada. Toda a estrutura foi modificada pois dificultava o desenvolvimento de competências-chave devido à distância entre os profissionais afins.

A AES é uma empresa que aprende, menos por estratégia e mais por necessidade. A empresa é originária de uma divisão, o que gera dificuldade de manter o conhecimento que, apesar das normas e padrões, ainda estavam em grande parte na cabeça das pessoas. Não existia uma estratégia pré-definida de Gestão do Conhecimento. O conhecimento atualmente não é tratado como status ou poder mas sim como um nível de senioridade.

\subsubsection{Estrutura Organizacional}

\section{Nível de Formalização}

\section{SIEMENS}

Os processos são documentados segundo os critérios do Prêmio Nacional da Qualidade (PNQ). Não existe política documentada sobre o que se espera das pessoas em termos de compartilhamento de conhecimento. Isto acontece muito mais através da cultura. Existe o programa PMI@Siemens, que faz parte do "Siemens Management System" que fornece uma série de recomendações para o gerenciamento de projetos. Um dos entrevistados afirmou que "o conhecimento 
sozinho não faz muita coisa, precisa de um processo para transformá-lo em ação, que chamamos habilidade".

Os espaços físicos facilitam a troca informal de informações e fomentarm interações do tipo socialização. As divisórias são baixas, escuta-se o que as pessoas falam. Absorvem-se informações de maneira natural. Equipamentos também são compartilhados. Todo dia às $10 \mathrm{~h}$ e $16 \mathrm{~h}$ o pessoal costuma se encontrar no café. Na Siemens existem salas fechadas para diretores, muitas vezes não é possível falar diretamente com eles, tendo que falar com as secretárias antes.

\section{CAMARGO CORRÊA}

Foi incentivado o registro de trabalhos técnicos dos projetos através de um programa que culminou com a implantação do aplicativo denominado "Memória Técnica". Foi feito um levantamento de como as áreas deveriam agir como preparação para o desenvolvimento da ferramenta. Qualquer um pode colaborar, mas dentro do programa existem critérios para publicação e validação. Para a Memória Técnica não é necessário criar nada especial. Os consultores internos avaliam se o conteúdo é adequado e se é a melhor prática antes de validar. Os próprios colaboradores que registram e publicam podem tornar-se consultores internos. No espaço físico nada foi desenhado especificamente para uma troca informal de informações. O "lay-out” atual não interfere, é adequado. Salas fechadas não interferem na troca de conhecimento, o relacionamento é um problema maior. Nenhuma sala tem porta, só as de reunião. Não existem divisórias até o teto. Há troca de informação no espaço destinado ao café.

\section{AES ELETROPAULO}

Como um processo geral, os grupos inovam, a diretoria ou os comitês validam e as unidades disseminam os grandes temas. Não existe política formal para facilitar e reger os processos do conhecimento, só incentivo. O processo formal é baseado em treinamento e em tecnologia de informação, que passa por validação. A grande parte é informal. Pequenos assuntos são tratados por e-mail. 
Todo o "lay-out" foi desenvolvido em forma de células, de modo a deixar as pessoas mais próximas, facilitando o contato para o trabalho diário e a troca de experiências. A sala do diretor é a única fechada mas tem paredes de vidro. As outras baias não têm portas e as divisórias são baixas. Este "lay-out" foi proposital. Outra configuração, com divisórias ainda mais baixas, foi testada mas o pessoal reclamou de falta privacidade. Em cada andar foi criado um espaço para café e um espaço "fun", onde as pessoas podem se encontrar durante o dia para conversar e fazer pequenas reuniões.

\section{Critérios de Departamentalização}

\section{SIEMENS}

A Siemens está dividida em unidades de negócios, por área de atuação, por exemplo Energia, Transportes, Indústria,... Cada área de negócios tem departamentos similares, apenas alguns são corporativos, como Recursos Humanos, Comunicação, Estratégia. A reduzida quantidade de níveis hierárquicos contribui para o fluxo de informações. A estrutura vertical é balanceada com uma estratégia de integração horizontal (programa denominado "One Siemens"). É aplicado ainda o princípio dos 4 olhos, onde cada unidade de negócios ou departamento é administrado por duas pessoas concomitantemente, uma mais técnica, a outra mais comercial. Os dois são subordinados a diretores ou gerentes gerais diferentes para manter a independência. São 4 olhos sobre custos, investimentos, etc...

Existe o departamento corporativo de Informação e Operações, dentro dele está um Gerente de Tecnologia da Informação e Conhecimento que não tem uma função operacional com relação à Gestão do Conhecimento, mas estratégica. Envolve comunidades, "Balance Score Cards", internet, colaboração, estruturação de conteúdos. Existe ainda um Comitê de Gestão do Conhecimento que é uma estrutura formal, com representantes de todas as áreas de negócios, multidisciplinar. O comitê discute a estratégia e a desdobra para as unidades de negócios. Este comitê é responsável por olhar todas as unidades de negócios, integrar as áreas e mapear todas as iniciativas em Gestão do Conhecimento. 
Existem equipes multidisciplinares para diversos assuntos que são montadas para resolver problemas. É a idéia de redes dinâmicas. O próprio comitê de Gestão do Conhecimento é um exemplo de equipe multidisciplinar. Normalmente são projetos de melhoria com objetivos claros e cobrança por resultados. Os grupos usualmente têm autonomia pois contam com um padrinho com poder na empresa. As equipes são normalmente temporárias e de dedicação parcial. Dedicação integral somente em projetos específicos e de longo prazo.

Os comitês têm um caráter mais decisório e trabalham com hierarquia própria. As equipes são normalmente formadas por decisão da diretoria mas alguns grupos são formados por iniciativa dos funcionários. A formação destas equipes é muito incentivada. Em sua maioria são ligadas à inovação, são temporárias, têm autonomia e seus membros dedicam-se parcialmente. Quase todos na empresa fazem algo além da sua função. Ou trabalha em um projeto, ou atua em um comitê. Segundo opinião de um entrevistado: "Os grupos são oportunidades para contato com outras áreas e pessoas da empresa e para aprender. É quase um MBA".

\section{CAMARGO CORRÊA}

A Camargo Corrêa também está dividida em unidades de negócios, por área de atuação, controladas por uma "Holding", e os exemplos são os mesmos: Energia, Transportes, Indústria. As unidades são estruturadas por projetos para os quais é escolhida uma equipe que se junta fisicamente inclusive. Não existe uma área específica de Gestão do Conhecimento, a função está disseminada na empresa. Existem equipes multidisciplinares de caráter temporário que estão normalmente envolvidas com projetos de redução de custos, melhoria de qualidade ou busca de alternativas tecnológicas. Os resultados do grupo, ao final, passam por uma validação da diretoria. Entende-se que não se deve ter uma área responsável pela tomada de decisão com relação à Gestão do Conhecimento, tem que ser disseminado ou deve ser um grupo multidisciplinar a cuidar do assunto. E cada área deve ter a possibilidade de desenvolver suas próprias experiências. A Gestão do Conhecimento não deve ter um dono. 
$\mathrm{Na}$ "Holding" da Camargo Corrêa existe uma área de inovação estratégica que têm iniciativas na área de Gestão do Conhecimento.

\section{AES ELETROPAULO}

A AES está dividida em 6 unidades de negócios distribuídas geograficamente que cuidam da operação da empresa mas que não têm independência total, pois existem algumas áreas centrais cujo objetivo é concentrar o conhecimento básico - para que ele migre às unidades com treinamento - e para estabelecer procedimentos e padrões para ação das unidades. Com isto a isto a empresa tem identidade, evolui de maneira mais ordenada e o conhecimento flui melhor. Um dos objetivos das unidades é conhecer de perto seus clientes pois as regiões têm características próprias. A Estrutura Organizacional da AES foi muito instável nos últimos anos. A empresa passou por muitas reestruturações em pouco tempo. Talvez tenha até sido proposital, pois como existia uma cultura forte de estatal, esta tática pode ter sido utilizada para fazer as pessoas esquecerem com o que elas estavam acostumadas.

A Gestão do Conhecimento está dentro das responsabilidades das diretorias de Engenharia e de Planejamento e algumas iniciativas estão ligadas à área de RH. Nas áreas centralizadas estão as pessoas que mais conhecem os processos da empresa justamente para fazer o trabalho de avaliação, revisão e disseminação para as áreas de operação.

É uma prática comum na empresa trabalhar com grupos multidisciplinares. Juntam-se assunto, líder e pessoas de diversas áreas. Normalmente a iniciativa nasce na diretoria que forma um grupo nomeando um líder e fixando metas e prazos. Os resultados são apresentados à área beneficiada e à diretoria para validação. As equipes multidisciplinares acompanham o andamento do processo e se dissolvem quando o problema está resolvido. Como existe um grande envolvimento da diretoria, as equipes têm grande autonomia. Existem ainda os chamados Pequenos Grupos Autônomos que correm paralelos à estrutura. Os líderes nos grupos não necessariamente o são na hierarquia formal. Existem 
grupos que estão no Planejamento Estratégico da empresa, onde um líder é nomeado pela diretoria para desenvolver um tema. Quando a equipe é formada espontaneamente, então o líder costuma surgir naturalmente. Normalmente são projetos de melhoria e inovação com grupos temporários e membros de dedicação parcial.

\section{Atribuições: Atividades}

\section{SIEMENS}

O líder recebe uma orientação informal para fomentar o trabalho em equipe, disseminar as informações, prover os recursos necessários para o desempenho da atividade. O líder é considerado um agente de mudanças, um multiplicador. Existe também o "Siemens Leadership Framework" que relaciona as sete competências que um líder deve ter. Líder é entendido como uma pessoa com mais de 3 subordinados.

\section{CAMARGO CORREA}

Não há nenhuma atribuição especial formal para o líder com relação à facilitar a geração e disseminação do conhecimento.

\section{AES ELETROPAULO}

Os líderes são responsáveis pelos processos. A empresa tem a expectativa que todo líder eleve o nível de sua equipe. O líder é instruído informalmente a atuar de maneira a facilitar a transmissão do conhecimento. Porém aqui nasce o conflito, pois a disseminação do conhecimento é uma meta de médio prazo que concorre com metas de curto prazo nas prioridades dos gerentes. 


\section{Atribuições: Níveis de Decisão}

\section{SIEMENS}

Pessoas que não detém todo o conhecimento ainda decidem. Tradicionalmente a Siemens é baseada em poder. Se o colaborador não tem o poder adequado tem que escalar para conseguir uma decisão. Há estímulo para experimentação e liberdade para tentar e falhar. No passado o erro não era muito tolerado e, em conseqüência, não se tomava muito risco. Hoje está mudando bastante, o erro é admitido. As pessoas não são necessariamente crucificadas e as tentativas audaciosas que não deram certo viram lições aprendidas.

\section{CAMARGO CORRÊA}

O poder de decisão está em níveis superiores, pois algumas decisões podem ser estratégicas, mas existe abertura para o fluxo de informação. Quem decide é fundamentado pela análise e conhecimento dos que estão abaixo dele. Pode até não ser a melhor decisão no curto prazo mas é vantajosa em longo prazo. Falhas viram lições aprendidas registradas em vídeo na Memória Técnica.

\section{AES ELETROPAULO}

Normalmente as decisões são compartilhadas, fruto de uma discussão. Em alguns casos o líder toma a decisão. A empresa incentiva que as pessoas tomem decisões, mesmo que isto possa levar a prejuízos. Com a redução de níveis hierárquicos isto ficou ainda mais latente. As equipes têm certa autonomia, mas sempre pedem o conselho do gerente. As pessoas decidem dentro de premissas, de limites. Normalmente limites orçamentários. Os técnicos decidem onde vão gastar, desde que respeitados os limites e premissas.

Com equipes mais maduras, o tentar e falhar é normal. Toda tentativa é feita em um ambiente controlado, com uma amostra, e, a partir dos resultados, implantam-se alterações nos processos. A empresa entende que as pessoas 
possam errar desde que não seja consciente ou por dolo. A AES trabalha com o conceito de pessoa de negócio. Pessoas que entendam do que ela faz e do negócio em si. Ela precisa conhecer o conjunto para entender as conseqüências dos seus atos. Novas tecnologias de manutenção são exemplos positivos de experimentação recente.

\section{Atribuições: Comunicação}

\section{SIEMENS}

O resultado do planejamento estratégico, princípios e valores são amplamente comunicados. Dificilmente um colaborador desconhece a estratégia. O colaborador precisa ser muito alienado para não tomar conhecimento. O diretor considera que todos têm que saber para onde se quer ir e para comunicação da estratégia foi criado o programa "Quero saber mais". São sessões de 2 horas com 50 a 100 pessoas reunidas em um auditório para discutir valores e estratégia com o diretor. Passa a mensagem que se o que o diretor sabe não é segredo, todos podem compartilhar o que sabem. Mas mesmo assim ainda há razão para querer que o conhecimento desça mais na estrutura: "Prefiro que o concorrente conheça a minha estratégia do que os funcionários não a conheçam".

Existe comunicação em todos os sentidos. O ambiente é informal e o acesso aos gestores é tranqüilo. A linguagem é comum, existem muitas abreviaturas mas a maioria conhece. Talvez alguma terminologia específica possa não ser entendida por todos. As informações são compartilhadas pela intranet, e-mail ou pessoalmente pela gerência. Existe amplo acesso, com ressalva para o pessoal de produção. Mas mesmo aqueles que não têm computador no cotidiano podem acessar os terminais disponíveis que contam inclusive com monitores. Faz parte do trabalho de inclusão digital.

A documentação do conhecimento ainda é considerada difícil. O principal incentivo para documentação do conhecimento é o próprio resultado que o indivíduo atingirá. Existe o Siebel, ferramenta de CRM, a Sharenet, de registro do 
conhecimento e lições de projetos. Não existe uma política de incentivo ao relacionamento face a face, somente ações pontuais.

Para disseminação do conhecimento, existe ainda um programa chamado "happy hour do saber" . Quem quer pode fazer uma apresentação de uma hora sobre a sua especialidade e será ouvido por interessados também voluntários. Isto aumenta a visibilidade do colaborador, que passa a ser uma referência no tema. Existe também o "café da manhã com o diretor". Além disto são utilizadas reuniões por computador ("netmeeting") para comunicação ou treinamento.

A Siemens tem uma cartilha que orienta a colaboração pois acredita que para aprender deve-se usar o canal certo na medida adequada. Existe um aplicativo de gerenciamento de documentos, com controle de revisão, fluxo de trabalho, etc... Dentro da Sharenet existem centenas de fóruns de debate que são de iniciativa dos colaboradores. O fórum é um meio de aceleração da aquisição do conhecimento.

Existem comunidades de prática globais e regionais. As comunidades são um macro-assunto onde existem fóruns, base de informação, ... Comunidades globais são mais verticalizadas e já somam mais de 20.000. Existe um padrão mundial para criação e forma de trabalho das comunidades de prática com moderador e incentivador. O comitê de Gestão do Conhecimento dá dicas para criar e manter de comunidades, mas quer uma administração descentralizada. $\mathrm{O}$ próprio comitê de Gestão do Conhecimento também é uma comunidade de prática.

\section{CAMARGO CORREAA}

A macro-estratégia e os resultados são informados mas não chegam com detalhes ao nível operacional. Há comunicação em todos os sentidos, porém a empresa tem muitos níveis hierárquicos, e isto é crítico. Se existissem menos, as comunicações seriam melhores. Os grupos são multidisciplinares justamente para nivelar este vocabulário. Acontece com mais freqüência do pessoal operacional 
ter uma linguagem ininteligível pelos administrativos do que o contrário. Os operacionais valorizam quem conhece a linguagem deles.

O acesso às informações não é liberado a todos, só até o nível gerencial. Este nível gerencial pode liberar para os demais. É incentivado o registro de trabalhos técnicos dos projetos. Para a Memória Técnica não é necessário criar nada especial. Um dos requisitos do projeto "memória técnica" era que a colaboração tinha que ser livre. Existe senha para o sistema mas ela é fornecida a quem solicita. Cerca de $95 \%$ das informações do sistema não são protegidas.

Para melhorar a comunicação, todos os dias os operacionais conversam com o seu gerente sobre serviço. Isto já está bem disseminado nos projetos. Nas obras o relacionamento mais freqüente já é o face a face.

Existe um incentivo e um procedimento formalizado para disciplinar a documentação do conhecimento. O incentivo é a premiação para as melhores publicações. Os gestores da "memória técnica" viajaram pelas obras divulgando a ferramenta. Os principais instrumentos de colaboração são a própria "memória técnica", um aplicativo de projeto compartilhado, um sistema de relacionamento com o cliente (CRM) e a memória organizacional. A memória técnica é utilizada para registros de conhecimentos explícitos escritos e também de alguns vídeos onde a pessoa aparece explicando alguma operação ou onde aparecem pessoas trabalhando e manuseando equipamentos.

Existem comunidades de prática mas não com este nome. A "Holding" tem um aplicativo onde as comunidades de prática, através do seu gestor, podem se cadastrar. Inclui fórum de debate.

\section{AES ELETROPAULO}

A comunicação da estratégia e dos resultados é o ponto forte da AES. Ela é feita numa reunião chamada "Business Review", que é uma análise do negócio, abrangendo todas as áreas, quando as pessoas passam um dia em um auditório mensalmente, discutindo os resultados. Todos tomam conhecimento da sua área 
e da dos outros. As pessoas entendem o negócio como um todo. Depois estas informações vão para rede e ficam disponíveis para todos.

A comunicação é sempre considerada um problema pelas pessoas. É comum elas se queixarem da falta de informação, mesmo estando ela disponível. Há uma preocupação na empresa para que as pessoas entendam que não estão escondendo nada delas. As informações são de acesso fácil, dificilmente uma pessoa receberá uma recusa de acesso a uma determinada área do sistema. As informações são compartilhadas via Lotus Notes, Intranet, SAP. Os funcionários, mesmo os operacionais, têm acesso à base de dados via Intranet. Para melhorar a comunicação a empresa instrui que a comunicação deve ser feita pelo líder da área e depois disponibilizada nos quadros de aviso. Em todas as unidades são distribuídas informações sobre indicadores técnicos e financeiros por internet ou quadros de avisos. Existe muita informação disponível, se a pessoa tiver interesse ela tem acesso a tudo. Às vezes a linguagem não é muito clara para todos.

Há o incentivo para documentação do conhecimento principalmente via Instruções de Trabalho que são operacionais, em sua maioria, e têm ênfase em segurança. São utilizados estes procedimentos de trabalho para padronizar a operação da empresa e treinar novas pessoas. O principal método de disseminação do conhecimento é o face a face, através do aprendizado durante o trabalho sob a supervisão de pessoas mais experientes. Para compartilhar alguns conhecimentos específicos de interesse comum são feitos "Workshops", quando reúnem-se pessoas representando várias áreas e uma delas faz uma apresentação das melhores práticas.

Comunidades de prática são ações espontâneas e isoladas. Um grupo interessado em um tema específico se reúne e, eventualmente, faz uma proposta para a empresa. Os grupos são criados exclusivamente por vontade dos funcionários e a forma de trabalho é totalmente livre. 


\subsubsection{Aprendizagem}

\section{SIEMENS}

A filosofia da empresa, contada por um colaborador, é que para gerar aprendizagem precisa-se colaborar de forma eficiente, senão gerará apenas caos informacional. Na organização é preciso aprender para crescer e a aprendizagem hoje é decisiva pois vivemos numa economia desmaterializada, onde o que agrega valor é a inteligência e não mais apenas o produto físico. Logo se tem que saber aprender mais rapidamente, se possível em tempo real. E o poder da aprendizagem em uma organização, como qualquer poder na física, é sempre o produto de uma tensão por uma intensidade. No caso do poder da aprendizagem é o produto da tensão para aprender pelo fluxo da informação. Para um aprender do outro, ambos precisam estar motivados, precisa-se querer isto. A partir deste estímulo motivacional e cultural é que se cria o fluxo de informação. No caos as pessoas interagem com muitas reuniões, muitos e-mails e telefonemas. Deste jeito não se pode aprender, pois não há estrutura. Aprender requer usar o canal certo na medida adequada.

$\mathrm{Na}$ Siemens existem diversos mecanismos de socialização do conhecimento dentro e fora da empresa. No relacionamento com os fornecedores existe o compartilhamento das melhores práticas e a premiação dos melhores fornecedores. A Siemens é uma empresa de tecnologia e seus parceiros são tecnológicos, para colaboração foi criado o "Portal da Tecnologia" na Internet. É um espaço onde qualquer parceiro ou parceiro potencial pode entrar e mostrar sua idéia e como ela se encaixa nos processos da Siemens. Isto vai para uma comunidade que analisa e valida. É uma ferramenta para captar inteligência do ambiente que já gerou muitos bons negócios. A participação em instituições de classe também foi citada como ferramenta de aprendizagem com parceiros.

Os próprios grupos são incentivos para contato com pessoas de outros departamentos. Existem portais com fornecedores onde se faz concorrência, e 
publicam-se informações relativas ao relacionamento com clientes e fornecedores.

A adesão aos grupos é "voluntária" entre aspas, pois aquele que não se interessa em compartilhar não serve para empresa. Para negar a participação tem que ter bons argumentos já que a empresa se considera uma rede global de inovação. Normalmente não são fornecidos prêmios ou reconhecimentos por resultados e contribuições extraordinárias, pois mais e mais está se criando a consciência de não incentivar as pessoas a fazerem aquilo para o qual elas já são remuneradas. E participar, compartilhar, inovar, faz parte do trabalho. Passou a ser parte da atividade do funcionário da Siemens. O funcionário entende que aquilo vai ser uma melhoria para a empresa e um aprendizado para ele. Alguns consideram um ponto fraco a política de reconhecimento apesar de existirem programas corporativos de premiação de sugestões para melhoramentos ou indicação de novos negócios.

A Siemens tem um outro exemplo interessante de que compartilhar faz parte de qualquer função. Existe uma equipe de professores voluntários de inglês. A empresa fornece o material didático que foi desenvolvido com auxílio de uma escola de idiomas e quem se interessar pode dar aulas no curso básico de inglês após um teste de proficiência. O grupo de funcionários-professores voluntários é um exemplo de criação de ambiente de compartilhamento e aprendizagem. É bom para o funcionário-professor que tem a oportunidade de relacionar-se com outras pessoas da empresa. É bom para os funcionários-alunos que aprendem gratuitamente um idioma, mesmo que em nível básico. E é bom para a empresa que além de desenvolver seus recursos humanos ainda os coloca em contato e oferece a oportunidade para que eles exercitem um dos princípios da empresa: a responsabilidade empresarial. Passando a mensagem aos demais que compartilhar faz parte de qualquer função. É importante salientar que não é uma economia para a empresa, pois os que freqüentam as aulas são aqueles cuja função não exige o conhecimento do idioma - pelo menos ainda - e para os quais a empresa não subvencionaria o curso regular. 
A rotação de pessoal é um mecanismo importante e incentivado, inclusive internacionalmente, pela Siemens. Não é algo imposto, cada um é responsável pela sua carreira. As pessoas procuram e acham um novo espaço e o líder atual dificilmente cria barreiras. A empresa é um campo muito rico, pois tem diversas áreas distintas, com isto pode-se ficar 20 anos na Siemens e ter a impressão que passou por diversas empresas. Do ponto de vista motivacional é muito interessante e a empresa facilita, com isto as pessoas transportam o conhecimento adquirido e, ao mesmo tempo, expandem o conhecimento delas. Não existe um programa formal mas é bastante praticado. Está incorporado na cultura. Existe orientação para buscar alternativas de contratação primeiro internamente.

Existem diversos instrumentos de registro e resgate de lições aprendidas mas eles não são unificados. Tem um para cada unidade de negócios. $A$ Sharenet é um deles. A empresa sente falta de algo transversal.

\section{CAMARGO CORREA}

Não há nenhuma metodologia formal de aprendizagem com organismos externos. A construtora tem um sistema de relacionamento com clientes. Somente os consultores estão obrigados a registrar a consultoria. Com parceiros e clientes existem apenas mecanismos de colaboração, registro de atividades, acompanhamento, $\ldots$

Todo mês há uma correspondência para todos os funcionários da empresa levando ao conhecimento quais os que mais contribuíram e o que eles fizeram. Isto é uma forma de reconhecimento e oportunidade. Existe um prêmio anual para os que fazem registro. Na memória técnica é possível inscrever seu trabalho. Ele passa por uma votação eletrônica que gera uma lista de finalistas e o ganhador e definido em uma banca de diretores. O prêmio é uma viagem ao exterior para evento técnico, representando a empresa, como reconhecimento à qualidade da publicação. 
Não há nenhum estímulo específico à rotação de pessoal, mas aqueles que publicam bons trabalhos tornam-se mais visíveis e podem vir a ser chamados para trabalhar em outros projetos ou departamentos.

A memória técnica é um instrumento de registro e resgate de lições aprendidas. Não necessariamente são registros de algo que o colaborador desenvolveu, podem ser de aprendizados de outras fontes.

Na opinião de um dos entrevistados, a Gestão do Conhecimento não é algo fácil de implantar, pois mexe com paradigmas de poder e, por isto, é importante que venha de cima, com uma estratégia bem desenhada da diretoria para que as pessoas, pelo menos, aceitem conversar do assunto. No início a ferramenta tem que ser suportada pela equipe de implantação, pois as pessoas podem encarar isto como uma tarefa adicional.

\section{AES ELETROPAULO}

Muita experiência é trocada com empresas que compõe o setor energético. Recentemente foi organizado pela AES um seminário com empresas e órgãos governamentais do setor com objetivo de trocar experiências e conhecimento. $\mathrm{Na}$ fundação COGE, que congrega empresas do setor energético, existe a formação de grupos de discussão. O relacionamento com os clientes é regulado pela agência e o relacionamento com os fornecedores ainda é tradicional. Falta ainda uma consciência na AES que ela é a líder desta cadeia.

A participação em grupos de melhoria é valorizada como uma contribuição extraordinária. Na verdade a AES é uma empresa que espera sempre um algo mais do funcionário, um diferencial. A melhor maneira de se perder o emprego na AES é ficar fazendo a rotina na sua mesa. Independente do que aconteça existe uma política de bônus na empresa. A participação nos lucros é igual para todos. O bônus é para aqueles que se destacam, fornecendo algo mais e não é limitado aos gerentes. A diretoria indica quem receberá, por contribuições extraordinárias ou desempenhos excepcionais. Com a experiência de grupos que lidam com projetos importantes, notou-se que não é uma boa prática premiar isoladamente 
os bons resultados. Fazer premiação isolada gerou desconforto entre os grupos e dificultou a cooperação.

Não existe um estímulo oficial à rotação de pessoal mas é uma prática, mais com o pessoal técnico que com o comercial. Existe também a troca de líderes nas regionais. Quando há uma vaga em um departamento, antes de contratar fora ela é disponibilizada na Intranet. Quem quiser pode se candidatar, sem ficar mal visto pelos colegas. No primeiro período da AES houve uma rotação muito maior de pessoas que passaram a se conhecer melhor e a conhecer melhor também as tarefas dos outros, porém não havia estrutura para isto e algumas pessoas foram mal treinadas.

Não existe um instrumento de registro ou resgate de lições aprendidas. Quando acontece o aprendizado, a orientação é que, depois de validado, o procedimento seja alterado imediatamente. Para outros tipos de aprendizado, quando o projeto acaba o conhecimento fica só na cabeça das pessoas que participaram dele. 


\section{CAPÍtULO 7}

\section{Resultados e Conclusões}

"Conhecimento é poder." 


\section{CAPÍTULO 7: Resultados e Conclusões}

\subsection{INTRODUÇÃO}

Determinar quais os efeitos dos subsistemas componentes da estrutura organizacional na geração e disseminação do conhecimento é o objetivo principal proposto nesta pesquisa, conforme definido no capítulo 1 .

O foco foi concentrado na análise crítica do ciclo do conhecimento notadamente as fases de geração e disseminação - e como suas variáveis podem ser potencializadas pelos componentes das estruturas organizacionais das empresas estudadas no setor de energia.

Foi particularmente importante entender a cultura das empresas, como elas estão estruturadas e como as pessoas se organizam - mesmo que informalmente - dentro desta estrutura; como o conhecimento e as informações circulam, quais tipos de conhecimento são estes e como são gerados; se a empresa aprende com seus parceiros de negócios e quais processos são utilizados para disseminação dos novos conhecimentos.

Este capítulo apresenta primeiramente os resultados e conclusões deste trabalho de pesquisa para os temas Estrutura Organizacional e Gestão do Conhecimento. Em seguida são apresentadas as principais contribuições para o tema na visão do autor, sugestões para futuras pesquisas e as limitações do estudo.

\subsection{RESULTADOS E CONCLUSÕES}

Neste tópico são apresentados os resultados da pesquisa que consistem na identificação de como os temas Estrutura Organizacional e Gestão do Conhecimento são tratados nas empresas e na confrontação da análise e 
interpretação dos dados com os conceitos e práticas encontrados na literatura, com o modelo conceitual e com as hipóteses apresentadas no capítulo 5.

A partir desta comparação serão identificados os aspectos em que esta pesquisa reforça a literatura e aspectos em que os resultados do trabalho divergem ou apontam novas dimensões para reflexão. Ao fazer este esforço reflexivo espera-se contribuir para o desenvolvimento da teoria existente.

Convém ressaltar não ser o termo "hipótese" utilizado aqui com rigor formal estatístico, mas como suposições iniciais facilitadoras da análise dos dados. Conforme descrito no item 5.4.2, há o reconhecimento que isto acarreta diversas limitações, que estão listadas no item 7.6.

\subsubsection{Nível de Formalização - Processos Formais}

Pouco se viu nas empresas estudadas sobre critérios e políticas formais para reger processos de geração, validação e disseminação do conhecimento. $\mathrm{Na}$ Siemens existe a consciência da importância e da necessidade e pode ser resumida na frase de um entrevistado: "O conhecimento sozinho não faz muita coisa, precisa de um processo para transformá-lo em ação." Esta afirmação encontra respaldo na literatura em Drucker (1999:119) para quem a liderança mundial irá para aqueles que elevarem a produtividade dos trabalhadores do conhecimento de forma mais sistemática. E a dificuldade, segundo o autor, está em descobrir e definir a tarefa (processo) que possibilitará ao trabalhador converter conhecimento em ação.

A Camargo Corrêa implantou o aplicativo "Memória Técnica" que tem critérios formais para validação e disseminação do conhecimento. Na AES Eletropaulo não existe uma política formal mas a geração costuma estar concentrada nas equipes multidisciplinares, a validação é dada pela diretoria ou comitês - se existirem para o tema - e às unidades cabe a disseminação.

O caso da Camargo Corrêa satisfez a hipótese de que uma estrutura formal, no caso a "Memória Técnica", fornece respaldo oficial ao conhecimento a 
ser disseminado, principalmente o explícito pois permite validar através de mecanismos reconhecidos normativamente pela organização.

\subsubsection{Nível de Formalização - Espaços Físicos}

As três empresas informaram que seus espaços físicos abertos, com divisórias baixas e salas sem portas - facilitando o acesso aos líderes fomentam as interações entre as pessoas. Foi igualmente recorrente a citação de encontros freqüentes na área reservada ao café.

Esta prática encontra respaldo nas palavras de Davenport e Prusak (1998:107) que apontaram as conversas em bebedouros ou máquinas de café como uma das estratégias mais eficazes para transferência do conhecimento.

Sveiby (1997:87), da mesma opinião, afirma ser a socialização através de ambientes abertos uma das estruturas para transmitir conhecimento tácito.

\subsubsection{Critérios de Departamentalização}

Quando a AES Eletropaulo, no final de 2000, acabou com as áreas centralizadas, dividindo a empresa em Unidades de Negócios independentes, as pessoas passaram a interagir mais e aprender o que os outros faziam pois poucas pessoas cuidavam de todos os processos. Foi uma fase de alavancagem do conhecimento. A estrutura descentralizada possibilitou que nas pequenas unidades de negócios as pessoas tivessem mais contato entre si e assim o conhecimento coletivo cresceu. Porém entre as unidades não existiu coordenação, assim foram sendo criadas diversas linhas de pensamento e ação dentro da mesma empresa. Ela perdia identidade devido à independência das Unidades de Negócios.

As ações deste período seguiram a mesma linha de pensamento das seguintes hipóteses: 
a existência de um grau relativamente alto de informalidade facilita e torna mais rápida a disseminação do conhecimento, principalmente o tácito pois estimula o contato social;

departamentos com fronteiras mais permeáveis facilitam a disseminação do conhecimento.

Após a criação das seis Unidades de negócios distribuídas geograficamente, unidas e dependentes de uma área central, cujo objetivo é concentrar o conhecimento e estabelecer procedimentos e padrões, a empresa recuperou a identidade perdida, evoluiu de maneira mais ordenada e o conhecimento fluiu melhor entre as Unidades de Negócios. Com esta solução a AES Eletropaulo obteve equilíbrio entre a necessidade de flexibilidade - porque o conhecimento muda - e a padronização - para que possa ser usado por várias pessoas - conforme preconizam Davenport e Prusak (1998:191).

\subsubsection{Critérios de Departamentalização - Administração do Conhecimento}

As três empresas apresentaram formas diversas de localização da Gestão do Conhecimento na Estrutura Organizacional formal.

Na Siemens existe o cargo específico de Gerente de Tecnologia da Informação e Conhecimento que tem função estratégica em relação à Gestão do Conhecimento. O desdobramento desta estratégia é feito pelo comitê de Gestão do Conhecimento, uma estrutura formal, com representantes de todas as áreas de negócios.

Já a Camargo Corrêa e a AES Eletropaulo não apresentaram áreas específicas para Gestão do Conhecimento, a responsabilidade está disseminada pela empresa.

Desta maneira, não foi possível verificar os preceitos da hipótese de que a criação de um departamento ou função específica para área de Gestão do Conhecimento facilita a geração e a disseminação do conhecimento, pois mesmo 
na Siemens, onde há esta função, existe um comitê multidisciplinar responsável por grande parte das atividades táticas.

A prática das empresas encontra apoio na afirmação de Choo (2003:351) que a "organização do conhecimento" adota um processo contínuo de construção social e coletiva, incorporado às tarefas.

Oliveira Jr. (1999:216), na conclusão de seu trabalho, pondera que a eventual criação de cargos responsáveis pela Gestão do Conhecimento é mais adequada se combinada com cargos de linha, eliminando o risco de modismos e fortalecendo a perspectiva de que a administração do conhecimento é responsabilidade de toda a empresa e não só de uma área.

Por outro lado contrasta com Davenport e Prusak (1998:129) que consideraram irrealista presumir que uma empresa possa simplesmente acrescentar atividades de Gestão do Conhecimento aos cargos existentes.

\subsubsection{Critérios de Departamentalização - Equipes Multidisciplinares}

Houve grande convergência entre as políticas adotadas pelas empresas estudadas em relação a este tema.

Na Siemens há uma cultura para o trabalho em equipe e utilização da estrutura matricial, combinando equipes multidisciplinares e o organograma funcional. Estas equipes são montadas para resolver problemas e seguem o princípio corporativo que os colaboradores trabalham em conjunto, criando uma rede global de conhecimentos e aprendizagem. Os grupos têm autonomia, são temporários e dedicam-se parcialmente. Quase todos na empresa fazem algo além da função. Na AES Eletropaulo e na Camargo Corrêa também existem equipes multidisciplinares com características similares às da Siemens.

Os dados levantados levam a crer que há grande convergência entre a prática das empresas e a hipótese que a geração do conhecimento é facilitada em organizações que possuem estruturas mais flexíveis, temporárias e autônomas, que facilitem a integração interfuncional e interdisciplinar. 
As equipes multidisciplinares também podem ser entendidas como a formação de uma estrutura matricial temporária na medida em que elas lidam com projetos ou problemas específicos e, em muitos casos, têm hierarquia própria e seus membros ainda continuam vinculados às suas atividades funcionais já que em sua maioria a dedicação foi declarada como parcial.

Esta afirmativa encontra respaldo em Oliveira Jr. (1999:162), para quem a estrutura matricial é uma boa forma de colocar as pessoas para trocar diferentes experiências, multiplicando as possibilidades de aprendizagem mútua.

Por outro lado o processo apresentado pelas empresas difere do pregado por Nonaka e Takeuchi (1997:194) pois os autores apresentaram uma organização em hipertexto com um nível equipes de projeto que representa a reunião de pessoas oriundas de diferentes unidades, mas os autores previam a dedicação exclusiva.

Já a proposta de Kruglianskas (1996, citado em Terra, 1999:108) reflete bem a realidade das empresas pesquisadas pois prevê uma ação estruturada, dirigida por objetivos estratégicos e pressupõe o trabalho conjunto de pessoas de diferentes departamentos e níveis hierárquicos, através de comitês.

A rede global de conhecimentos presente nos princípios da Siemens foi citada por Davenport e Prusak (1998:64) como um dos modos de geração do conhecimento. A resolução compartilhada de problemas é também, segundo Choo (2003:364), uma atividade criadora de conhecimento.

\subsubsection{Atribuições - Atividades (Papel do Líder)}

Neste tópico houve grande divergência entre as empresas. Não foi possível detectar nenhuma evidência de atribuições formais do líder na Estrutura Organizacional para facilitar a geração e disseminação do conhecimento em duas empresas estudadas, sendo que uma delas afirmou ser o líder instruído informalmente. 
Portanto a hipótese de que a geração do conhecimento é facilitada por um líder que inspire confiança, que estimule a aprendizagem contínua, que saiba ouvir e que seja comunicativo, não pôde ser verificada. Entende o autor que muito mais pela falta de evidências nas empresas e pela dificuldade de obtê-las do que por ser falsa a hipótese.

A importância do líder na empresa do conhecimento foi destacada por diversos autores, como Leonard-Barton (1995:78), Drucker (1992:76), Nonaka (1997:40), Senge (1997:345) entre outros. Romano e Dazzi (2002:54) e Clemes (2002:149) afirmaram especificamente ser do líder a responsabilidade de criação de um ambiente que favoreça a geração e disseminação do conhecimento.

\subsubsection{Atribuições - Níveis de Decisão}

Neste quesito as empresas foram unânimes: a decisão é, via de regra, feita pelos escalões superiores, fundamentados pela análise e pelo conhecimento dos seus auxiliares.

As equipes têm, geralmente, mais autonomia que os indivíduos, muitas vezes também por terem nos seus quadros um membro da alta administração ou um delegado dele. As pessoas normalmente têm limites de autoridade para decisões. A experimentação é estimulada e a falha é admitida. As empresas pesquisadas declararam transformar os erros em lições aprendidas ou mudanças imediatas nos processos.

Este resultado coincide com o apresentado por Terra (1999:205) que mostrou serem lentos, centralizados e burocráticos os processos decisórios nas empresas.

Segundo Leonard-Barton (1995:117) idéias experimentais criam o futuro e é função dos gerentes criar um clima organizacional que aceite e encoraje esta atividade. 
A tomada de decisão no topo da organização encontra raros adeptos na literatura. A grande maioria dos autores defende a descentralização e o empoderamento dos detentores do conhecimento.

Vasconcellos (1989:4) ressalta a necessidade de equilíbrio já que as decisões excessivamente centralizadas resultam em demora, sobrecarga e decisões desvinculadas da realidade. E a descentralização extrema, por sua vez, significa falta de coordenação e dificuldade de controle.

Blanchard e outros (1996) consideram a transferência de autoridade e responsabilidade às equipes uma condição essencial para um bom desempenho.

Nas empresas estudadas observou-se grande preocupação com o fluxo do conhecimento no sentido de quem decide, o que condiz com a hipótese de que a necessidade de disseminação é reduzida em organizações cujo poder de decisão está próximo do conhecimento. Entretanto a hipótese de que nas organizações onde o poder de decisão está próximo do conhecimento, a geração de novos conhecimentos é facilitada, não encontrou apoio.

\subsubsection{Comunicação}

As empresas comunicam, em maior ou menor grau, suas estratégias e resultados aos colaboradores. Isto reforça a hipótese que o compartilhamento dos resultados com os colaboradores pela liderança estimula disseminação futura de conhecimento.

Todas as empresas declararam que existe comunicação em todos os sentidos e que o acesso aos gestores é tranqüilo. $O$ acesso à base de dados também foi uma unanimidade e vários entrevistados enfatizaram os esforços para que até mesmo os funcionários mais operacionais, que não têm computador, possam ter as informações desejadas.

Com relação a instrumentos para disseminação e compartilhamento do conhecimento a Camargo Corrêa demonstrou forte incentivo e uso de tecnologia para documentação e disponibilização de documentação técnica de projetos, 
incluindo lições aprendidas. É o conceito da "Memória Técnica". O estímulo envolve um prêmio anual para os melhores registros.

O apoio na literatura para esta prática vem de Nonaka (1997:30) que afirmou que tornar o conhecimento pessoal disponível para os outros é a atividade central da empresa criadora do conhecimento. Além deste, muitos outros autores defendem esta postura, como Dixon (2000:15), Choo (2003:197), Shaw e Perkings (1993:160).

$\mathrm{Na}$ AES Eletropaulo existe a documentação do conhecimento via Instruções de Trabalho, mas é mais comum a disseminação do conhecimento através do aprendizado durante o trabalho sob supervisão de colegas mais experientes. A AES espera sempre algo mais do funcionário e existe uma política de bônus para aqueles que se destacam, não limitada a gerentes.

$\mathrm{Na}$ Siemens observaram-se muitas iniciativas para disseminação do conhecimento tácito, como o "happy hour do saber" e as mais de 20.000 comunidades de prática globais. A empresa tem programas corporativos de premiação de sugestões para melhoramento ou indicação de novos negócios. Entretanto está se criando uma consciência coletiva de não incentivar as pessoas a fazerem aquilo para o qual elas já são remuneradas. A empresa entende que inovação e compartilhamento fazem parte do trabalho e, portanto, não são fornecidos prêmios por resultados ou contribuições extraordinárias.

Esta prática encontra suporte na literatura através de Stewart (2001:185) para quem as pessoas precisam estar conscientes que é parte do trabalho delas fazer mais do que o trabalho delas.

Quando se trata de comunicação e aprendizado com o ambiente externo, observou-se ser a iniciativa baseada nos clientes a mais recorrente, normalmente através de contato pessoal e de aplicativos de gerenciamento do relacionamento (CRM). Existem também atividades relacionadas aos fornecedores, aí incluídos os consultores que em uma das empresas pesquisadas são solicitados a documentar detalhadamente os serviços fornecidos e os conhecimentos gerados. 
Existe também a troca de experiências entre empresas que compõe o setor energético através de participação em entidades de classe e seminários.

Esta política está coerente com a afirmação de Shaw e Perkins (1993:168) que uma atitude importante na criação de uma empresa eficiente em aprender é a abertura dos limites da organização às novas idéias e informação provenientes de clientes, fornecedores, seminários ou novos funcionários recrutados externamente.

Nas empresas pesquisadas não existe um estímulo oficial para disseminação do conhecimento e aprendizagem através da rotação de pessoal mas, apesar de não formalizada, costuma ser uma prática corrente. Existindo inclusive a orientação de buscar alternativas internas antes de contratar um novo funcionário. Esta prática está apoiada na literatura desenvolvida por Hamel e Prahalad (1995:270), Krogh e outros (2001:243), Robbins (2002:447), Stewart (2001:202) e outros autores.

Estas afirmações todas apontam no mesmo sentido que as hipóteses sobre comunicação, apresentadas na Figura 16 no sub-item de Comunicação.

Assim, este trabalho procurou aproximar e relacionar as abordagens mais recentes sobre Estrutura Organizacional e Gestão do Conhecimento, tendo como base a revisão bibliográfica e as práticas empresariais obtidas na pesquisa de campo. Com isso foi atingido o objetivo do presente trabalho, ou seja, estudar o efeito dos subsistemas componentes da estrutura organizacional na geração e disseminação do conhecimento.

\subsection{QUADRO RESUMO DOS RESULTADOS}

Para facilitar a visualização dos resultados, é apresentado o seguinte quadro resumo: 


\section{COMPONENTES DA ESTRUTURA ORGANIZACIONAL}

RESULTADOS

\begin{tabular}{|c|c|}
\hline $\begin{array}{l}\text { Nível de Formalização - } \\
\text { Processos Formais }\end{array}$ & $\begin{array}{l}\text { Pouco se viu nas empresas estudas sobre critérios e políticas } \\
\text { formais para reger processos de geração, validação e } \\
\text { disseminação do conhecimento. Um exemplo positivo foi o } \\
\text { aplicativo "Memória Técnica" da Camargo Corrêa em cujo } \\
\text { processo de publicação inserem-se normas de validação de } \\
\text { conteúdo. }\end{array}$ \\
\hline $\begin{array}{l}\text { Nível de Formalização - } \\
\text { Espaços Físicos }\end{array}$ & $\begin{array}{l}\text { As três empresas informaram que seus espaços físicos } \\
\text { abertos, com divisórias baixas e salas sem portas - facilitando } \\
\text { o acesso aos líderes - fomentam as interações entre as } \\
\text { pessoas. Foi igualmente recorrente a citação de encontros } \\
\text { freqüentes na área reservada ao café. }\end{array}$ \\
\hline $\begin{array}{l}\text { Critérios de } \\
\text { Departamentalização }\end{array}$ & $\begin{array}{l}\text { Em estruturas mais descentralizadas existe facilidade para } \\
\text { disseminação do conhecimento existente, já que todos estão } \\
\text { mais próximos dos especialistas pois eles estão distribuídos } \\
\text { pelas unidades, porém há dificuldade para geração de novos } \\
\text { conhecimentos ou manutenção de um padrão de atuação pois } \\
\text { os detentores do conhecimento estão dispersos pela empresa. } \\
\text { O ideal é implantar uma solução que equilibre a necessidade } \\
\text { de flexibilidade (porque o conhecimento muda) e a } \\
\text { padronização (para que possa ser usado por várias pessoas). }\end{array}$ \\
\hline $\begin{array}{l}\text { Critérios de } \\
\text { Departamentalização - } \\
\text { Administração do } \\
\text { Conhecimento }\end{array}$ & $\begin{array}{l}\text { As três empresas apresentaram formas diversas de localização } \\
\text { da Gestão do Conhecimento na Estrutura Organizacional } \\
\text { formal. Porém todas apresentaram convergência no sentido de } \\
\text { descentralizar a Gestão do Conhecimento. Mesmo onde havia } \\
\text { função específica para gerir o conhecimento, existia um comitê } \\
\text { multidisciplinar responsável por grande parte das atividades } \\
\text { táticas. }\end{array}$ \\
\hline \multirow[t]{2}{*}{$\begin{array}{l}\text { Critérios de } \\
\text { Departamentalização - } \\
\text { Equipes } \\
\text { Multidisciplinares }\end{array}$} & $\begin{array}{l}\text { Houve grande convergência entre as políticas adotadas pelas } \\
\text { empresas estudadas em relação a este tema. Há uma cultura } \\
\text { para o trabalho em equipe e utilização da estrutura matricial, } \\
\text { combinando equipes multidisciplinares e o organograma } \\
\text { funcional. Estas equipes são montadas para resolver } \\
\text { problemas melhorar os processos. Os grupos têm autonomia, } \\
\text { são temporários e dedicam-se parcialmente. Quase todos nas } \\
\text { empresas fazem algo além da função. }\end{array}$ \\
\hline & $\begin{array}{l}\text { As equipes multidisciplinares também podem ser entendidas } \\
\text { como a formação de uma estrutura matricial temporária na } \\
\text { medida em que elas lidam com projetos ou problemas } \\
\text { especificos e, em muitos casos, têm hierarquia própria e seus } \\
\text { membros ainda continuam vinculados às suas atividades } \\
\text { funcionais já que em sua maioria a dedicação foi declarada } \\
\text { como parcial. }\end{array}$ \\
\hline
\end{tabular}




\begin{tabular}{|c|c|}
\hline $\begin{array}{l}\text { COMPONENTES DA } \\
\text { ESTRUTURA } \\
\text { ORGANIZACIONAL }\end{array}$ & RESULTADOS \\
\hline $\begin{array}{l}\text { Atribuições - Atividades } \\
\text { (Papel do Líder) }\end{array}$ & $\begin{array}{l}\text { Neste tópico houve grande divergência entre as empresas. } \\
\text { Não foi possível detectar nenhuma evidência de atribuições } \\
\text { formais do líder na Estrutura Organizacional para facilitar a } \\
\text { geração e disseminação do conhecimento em duas empresas } \\
\text { estudadas, sendo que uma delas afirmou ser o líder instruído } \\
\text { informalmente. }\end{array}$ \\
\hline $\begin{array}{l}\text { Atribuições - Níveis de } \\
\text { Decisão }\end{array}$ & $\begin{array}{l}\text { Neste quesito as empresas foram unânimes: a decisão é, via } \\
\text { de regra, feita pelos escalões superiores, fundamentados pela } \\
\text { análise e pelo conhecimento dos seus auxiliares. As equipes } \\
\text { têm, geralmente, mais autonomia que os indivíduos, muitas } \\
\text { vezes também por terem nos seus quadros um membro da alta } \\
\text { administração ou um delegado dele. As pessoas normalmente } \\
\text { têm limites de autoridade para decisões. A experimentação é } \\
\text { estimulada e a falha é admitida. As empresas pesquisadas } \\
\text { declararam transformar os erros em lições aprendidas ou } \\
\text { mudanças imediatas nos processos. Nas empresas estudadas } \\
\text { observou-se, ainda, grande preocupação com o fluxo do } \\
\text { conhecimento no sentido de quem decide. }\end{array}$ \\
\hline \multirow[t]{2}{*}{ Comunicação } & $\begin{array}{l}\text { As empresas comunicam suas estratégias e resultados aos } \\
\text { colaboradores. O acesso à base de dados também foi uma } \\
\text { unanimidade. As empresas mostraram iniciativas e incentivos - } \\
\text { inclusive com uso de tecnologia - para documentação do } \\
\text { conhecimento, incluindo lições aprendidas. Foram também } \\
\text { observadas algumas iniciativas para disseminação do } \\
\text { conhecimento tácito. Nas empresas pesquisadas não existe } \\
\text { um estímulo oficial para disseminação do conhecimento e } \\
\text { aprendizagem através da rotação de pessoal mas, apesar de } \\
\text { não formalizada, costuma ser uma prática corrente. }\end{array}$ \\
\hline & $\begin{array}{l}\text { Quando se trata de comunicação e aprendizado com o } \\
\text { ambiente externo, observou-se ser a iniciativa baseada nos } \\
\text { clientes a mais recorrente, normalmente através de contato } \\
\text { pessoal e de aplicativos de gerenciamento do relacionamento } \\
\text { (CRM). }\end{array}$ \\
\hline
\end{tabular}

Figura 19. Quadro Resumo dos Resultados

Fonte : Elaborado pelo autor

\subsection{CONTRIBUIÇÕES PARA O TEMA}

Este tópico contém a visão pessoal do autor sobre a contribuição deste trabalho para os temas Estrutura Organizacional e Gestão do Conhecimento.

Sem dúvida a pesquisa deu suporte à literatura que considera a Estrutura Organizacional um tópico de grande valor para a Gestão do Conhecimento. 
Muito se tem falado e escrito sobre Gestão do Conhecimento nas organizações, mas levar a teoria à prática tem sido uma barreira de difícil transposição. Quase sempre tudo começa com a dúvida sobre a criação de uma área específica para administração de assuntos do conhecimento ou a aquisição de um aplicativo disponível no mercado.

A revisão bibliográfica apresentada e, principalmente, a pesquisa de campo, mostraram que uma área especificamente dedicada ao conhecimento pode ajudar, porém, fundamental mesmo é a existência de comitês estratégicos formados por membros de diferentes especialidades, ocupantes de cargos de linha, em regime de dedicação parcial. Estas equipes logicamente não garantem que todas as necessidades da empresa serão contempladas, mas reduzem bastante a possibilidade de algum aspecto importante não ser considerado ou de alguma área ser esquecida. E reforçam a sensação de que o conhecimento não é responsabilidade de um departamento mas de toda a empresa.

O estudo mostrou também que os líderes exercem papel vital na organização que depende do conhecimento. Cabe a eles o incentivo ao desenvolvimento de ambiente, cultura e valores que valorizem a sinergia, a aprendizagem e o compartilhamento do conhecimento combinado à comunicação eficaz dos objetivos e estratégias da organização.

É importante ressaltar que a preocupação com a geração e disseminação do conhecimento não é um tema novo, entretanto um dos maiores facilitadores do desenvolvimento da Gestão do Conhecimento foi o aumento das possibilidades de comunicação e processamento de informações. Reforça-se neste trabalho a importância pela documentação - quando viável - do conhecimento validado e pela criação de oportunidades de contatos pessoais, por favorecem o reuso e compartilhamento do conhecimento, conferindo competitividade à empresa. Incluise aqui o acesso à base de dados da organização e o estímulo à contribuição de qualquer funcionário como ações a serem consideradas em programas de reutilização e compartilhamento de conhecimento. 
O estudo mostrou também que apesar dos esforços dos autores em mostrar que o ideal seria a decisão ser tomada no ponto mais próximo do conhecimento na estrutura, ainda existem dificuldades e restrições por parte dos gestores em aplicar esta teoria. A principal razão seria que o tomador de decisão deve ter uma visão global do negócio para identificar eventuais conseqüências deste ato em outras áreas. Este efeito poderia ser minimizado através da divulgação dos objetivos e estratégias da empresa. Porém ainda permanece na mente dos gestores a dúvida se a mensagem foi realmente compreendida pelos detentores do conhecimento e se eles reúnem bagagem suficiente para suportar a necessária visão holística sobre as conseqüências da decisão deles.

Outra contribuição importante foi a presença da comunicação como um tópico altamente relevante para os dois temas em estudo. A comunicação é sempre um tema importante, mas quando se trata de gerenciar o conhecimento ela assume um papel de destaque já que o conhecimento tácito é transmitido através da comunicação entre as pessoas, face a face, e o conhecimento explícito depende de um sistema eficaz de comunicação para atingir aqueles que dele necessitam. $O$ estudo mostrou que muito tem sido feito neste sentido, porém muito ainda há para ser feito, principalmente no tocante à rotação de pessoal e comunicação ou aprendizagem com o ambiente externo à empresa.

Finalmente, a utilização de equipes multidisciplinares para resolução de problemas ou para o desenvolvimento de projetos de inovação e melhoria mostrou-se um instrumento poderoso principalmente se cultivada a diversidade de competência de seus membros, a dedicação parcial - para que o contato com o negócio não seja perdido - e o regime temporário para que objetivos tenham prazo para serem atingidos e para que os integrantes estejam disponíveis para formar novas equipes. Utilizar as equipes multidisciplinares como uma dimensão adicional da estrutura matricial parece ser uma fórmula adequada de administração do conhecimento.

O presente estudo permitiu concluir que a Estrutura Organizacional pode ter efeito substancialmente positivo sobre a Gestão do Conhecimento, principalmente quando adotadas as práticas de trabalho com equipes 
multidisciplinares para resolução de problemas ou projetos de melhoria e quando coexistirem sistemas de comunicação e ambiente propícios para o desenvolvimento de uma cultura de aprendizagem e compartilhamento do conhecimento através do contato pessoal, com adequado suporte de tecnologia. O objetivo seria implantar estruturas organizacionais que, pautadas pela estratégia, considerassem também as inúmeras possibilidades de interação entre pessoas e tecnologia da informação visando eficaz reutilização do conhecimento e aprendizado.

\subsection{FUTURAS PESQUISAS}

A partir deste estudo, muitas outras oportunidades de pesquisa surgiram. Temas que foram pouco desenvolvidos aqui ou temas de certa forma relacionados.

A primeira possibilidade seria abordar todo o ciclo do conhecimento descrito no item 3.4.2, e não somente a geração e disseminação como neste estudo. Isto daria uma visão global do processo e poderia trazer contribuições importantes, principalmente na dimensão "uso", que até o momento foi bem pouco explorada pelos autores.

O aprofundamento do estudo no tocante às equipes multidisciplinares seria de grande valia, pois elas reúnem tópicos de diversas disciplinas como gestão de projetos, gestão de pessoas, comunicação e estrutura organizacional entre outros. E, por isto, mostraram-se adaptadas às organizações que aprendem devido à suas características de flexibilidade, diversidade, permeabilidade das fronteiras, habilidade em compartilhar e criar.

A Gestão do Conhecimento ainda carece de um estudo mais profundo sobre as reais possibilidades em se ter indicadores de performance dos processos do conhecimento. Parece ser uma seara bastante árida na qual poucos autores se aventuraram, e o pouco que se tem ainda aparenta superficialidade. 
Um jargão recorrente prega que a Gestão do Conhecimento - ou suas subdisciplinas - devem estar alinhadas com a estratégia da organização, porém somente estudos pouco profundos foram encontrados sobre o tema. E sobre o tema reverso - planejamento estratégico para empresas intensivas em conhecimento - ainda menos interesse existiu até o momento.

\subsection{LIMITAÇÕES DO ESTUDO}

Por ser um estudo de caso, baseado em poucas empresas de um setor da economia, a presente pesquisa apresenta baixo poder de ampliação dos resultados para um universo maior.

Uma limitação inicial é o acesso como indivíduo externo, implicando que o pesquisador terá acesso limitado às informações. As empresas não puderam fornecer todas as informações com o detalhamento e profundidade desejados porque a pesquisa, em alguns momentos, abordou assuntos estratégicos, o que poderia expor, de modo indesejado, alguns pontos de importância vital. Além disto o pesquisador depende da honestidade dos entrevistados e da sua disposição em compartilhar experiências.

Apesar dos cuidados metodológicos descritos, visando a imparcialidade na coleta de dados, a realização de entrevistas em profundidade às vezes está sujeita a vieses pessoais do entrevistado ou do entrevistador. Um dos vieses se deve ao fato de que a maior parte dos entrevistados pertence à Gerência/Diretoria que faz com que a perspectiva dos escalões inferiores não esteja representada. Porém coletar informações dos escalões inferiores implicaria em um problema de compreensão do tema.

A pesquisa focou em geração e disseminação. O estudo do ciclo completo do conhecimento não se mostrou viável numa pesquisa com este prazo e abrangência. Provavelmente seria viável para uma empresa ou departamento específico. 
Os temas em estudo - Estrutura Organizacional e Gestão do Conhecimento - nem sempre encontrarão respaldo teórico nos respondentes, o que pode, eventualmente, causar desvios de entendimento das questões. 


\section{CAPÍtULO 8}

Referências

Bibliográficas

"O homem se distingue do animal porque compra mais livros do que pode ler."

Edward Lasker 


\section{CAPÍTULO 8: Referências Bibliográficas}

ADAMS, G. P. e outros. Knowledge and Society: A Philosophical Approach to Modern Civilization. New York: Appleton-Century, 1938.

ALBERT, Steven, BRADLEY, Keith. Managing Knowledge: Experts, Agencies and Organizations. Cambridge: Cambridge University Press, 1997.

ANGELONI, Maria Terezinha (coord.). Organizações do Conhecimento: infraestrutura, pessoas e tecnologias. São Paulo: Saraiva, 2002.

ARGYRIS, Chris; SCHÖN, Donald. Organizational Learning: A theory of action perspective. Readings, Massachusetts: Addison-Wesly, 1978.

BECKER, Gary S. Human Capital. Londres: The University of Chicago Press, 1993.

BLANCHARD, K. e outros. Empowerment. Rio de Janeiro: Objetiva, 1996.

BRUNO, Marcos, VASCONCELLOS, Eduardo. Effectiveness in the Management of Strategic Tecnological Alliances: conceptual framework and application to the chemical industry. Technology Management: Strategies \& Application, vol.3, pp. 313-327, 1997.

BUCKMAN, Robert H. Lions, Tigers and Bears. Buckman Laboratories Knowledge Nurture website (www.knowledge-nurture.com), 2000.

BUKOWITZ, W.R., WILLIAMS, R.L. Manual de Gestão do Conhecimento: Ferramentas e Técnicas que Criam Valor para a Empresa. Porto Alegre: Bookman, 2002.

CALDAS, M., WOOD Jr, T. Transformação e Realidade Organizacional: Uma perspectiva brasileira. São Paulo: Atlas, 1999.

CANOLA, Edgar G. A Hidroeletricidade no Brasil. Trabalho de Graduação. EEE/Mackenzie, 2002.

CARVALHO, D. T. Sistemas de Inteligência Competitiva. Dissertação de Mestrado, FEA/USP, 1995.

CHIAVENATO, Idalberto. Teoria Geral da Administração. Rio de Janeiro: Campus, 1999, Volume 2.

$\mathrm{CHOO}$, Chun Wei. A Organização do Conhecimento: como as organizações usam a informação para criar significado, construir conhecimento e tomar decisões. São Paulo: SENAC, 2003.

CLEMES, Sandro. Intuir e Conhecer: Uma perspectiva ampliada dos saberes organizacionais. In: ANGELONI, Maria Terezinha (coord.). Organizações do Conhecimento: infra-estrutura, pessoas e tecnologias. São Paulo: Saraiva, 2002.

CLEVELAND, Harlan. The Knowledge Executive: Leadership in an Information Society. New York: Truman Talley Books, 1985.

CRAWFORD, Richard. Na Era do Capital Humano. São Paulo: Atlas, 1994.

DAMIANI, Wagner B. Gestão do Conhecimento: Um Estudo Comparativo Brasil x Estados Unidos. Anais do XXV Enanpad, Campinas/SP, 2001. 
DAVENPORT, T., PRUSAK, L. Conhecimento Empresarial: Como as Organizações Gerenciam o seu Capital Intelectual. Rio de Janeiro: Campus, $1998,3^{\text {a }}$ ed.

DAVENPORT, T. Ecologia da Informação. São Paulo: Futura, 2000, $2^{\mathrm{a}}$ ed.

DIXON, Nancy M. Common Knowledge: How Companies Thrive by Sharing what They Know. Boston: Harvard Business School Press, 2000.

DIXON, Nancy M., ROSS, Rick. O Ciclo de Aprendizagem Organizacional. In: SENGE, P. e outros. A Dança das Mudanças. Rio de Janeiro: Campus, 1999.

DRUCKER, Peter. The Next Society. Artigo publicado na revista The Economist, 01/11/2001.

DRUCKER, Peter. Desafios Gerenciais para o Século XXI. São Paulo: Pioneira, 1999.

DRUCKER, Peter. A Profissão de Administrador. São Paulo: Pioneira, 1998.

DRUCKER, Peter. Sociedade Pós-Capitalista. São Paulo: Pioneira, 1995, 4ed.

DRUCKER, Peter. Administrando para o futuro. São Paulo: Pioneira, 1992, 4ed.

DUGUID, Paul, BROWN, J. S. Estrutura e Espontaneidade: Conhecimento e organização . In: FLEURY, Maria Tereza Leme, OLIVEIRA Jr, Moacir de Miranda (organizadores). Gestão estratégica do Conhecimento: integrando aprendizagem, conhecimento e competências. São Paulo: Atlas, 2001.

EBOLI, Marisa (org.). Universidades Corporativas. São Paulo: Schmukler, 1999.

EDVINSON, Leif, MALONE, Michael. Capital Intelectual. São Paulo: Makron Books, 1998.

EASTERBY-SMITH, M. THORPE, R. LOWE, A. Management Research. Londres: SAGE, 1991.

FLEURY, Maria Tereza Leme, OLIVEIRA Jr, Moacir de Miranda (organizadores). Gestão estratégica do Conhecimento: integrando aprendizagem, conhecimento e competências. São Paulo: Atlas, 2001.

FLEURY, M.T.L. Aprendizagem e Gestão do Conhecimento. In DUTRA,J.S. Gestão por Competências. São Paulo: Gente, 2001.

FLEURY, Afonso e FLEURY, Maria Tereza Leme. Estratégias Empresariais e Formação de Competências. São Paulo: Atlas, 2000.

FRIGOTTO, G. e outros. Trabalho e Conhecimento: Dilemas na Educação do Trabalhador. São Paulo: Cortez, 1995.

FULD, Leonard M. Competitor Intelligence. New York: John Wiley\&Sons, 1985.

GAJ, Luis. Administração Estratégica: O "Estado Da Arte". Conceitos, Técnicas e Sistema de Adequação Empresarial. Tese de Doutorado, FEA/USP,1986.

GALBRAITH, Jay. Projetando a Organização Inovadora. In: STARKEY, K. (org). Como as Organizações Aprendem. São Paulo: Futura, 1997.

GALBRAITH, Jay, LAWLER, E. Organizando para Competir no Futuro. São Paulo: Makron Books, 1995.

GALBRAITH, Jay. Organizational Design. Reading, USA: Addinson Wesley, 1977. 
GALBRAITH, Jay. Design Complex Organizations. Reading, USA: Addinson Wesley, 1973.

GATES, Bill. A Empresa na Velocidade do Pensamento. São Paulo: Companhia da Letras, 1999.

GERSTEIN, Marc. Das Burocracias Mecânicas às Organizações em Rede: Uma Viagem Arquitetônica. In: NADLER, David. e outros. Arquitetura Organizacional. Rio de Janeiro: Campus, 1993.

GERSTEIN, Marc, SHAW, Robert. Arquiteturas Organizacionais para o Século XXI. In: NADLER, David. e outros. Arquitetura Organizacional. Rio de Janeiro: Campus, 1993.

GIL, A.C. Como Elaborar Projetos de Pesquisa. São Paulo: Atlas, 1996.

GONTIJO, Adriana; PERROTTI, Edoardo; MANOEL, Jorge R. Capital Intelectual. Trabalho de Conclusão de Curso. MBA/USP, 2001.

GRAHAM, A.; PIZZO, V. Uma Questão de Equilíbrio: Estudos de casos na gestão estratégica do conhecimento. In: KLEIN, David. A Gestão Estratégica do Capital Intelectual: Recursos para a economia baseada no conhecimento. Rio de Janeiro: Qualitymark, 2002.

GROTTO, Daniela. O Compartilhamento do Conhecimento nas Organizações. In: ANGELONI, Maria Terezinha (coord.). Organizações do Conhecimento: infraestrutura, pessoas e tecnologias. São Paulo: Saraiva, 2002.

HAMEL, G., PRAHALAD, C. K. Competindo pelo futuro. Rio de Janeiro: Campus, 1995.

HESSELBEIN, F.; GOLDSMITH, M.; BECKHARD, R. A Organização do futuro. São Paulo: Futura, 1997.

HESSEN, Johannes. Teoria do Conhecimento. Coimbra: Armênio Amado, 1964, 3ed.

JENSEN, Michael; MECKLING, W. Specific and General Knowledge, and Organizational Structure. In: MYERS, Paul S (org). Knowledge Management and Organizational Design. USA: Butterworth-Heinemann, 1996.

KAHANER, Larry. Competitive Inteligence. New York: Simon\&Schuster, 1996.

KILMANN, Ralph. Desenhando Organizações Colaterais. In: STARKEY, K. (org). Como as Organizações Aprendem. São Paulo: Futura, 1997.

KLEIN, David. A Gestão Estratégica do Capital Intelectual: Recursos para a economia baseada no conhecimento. Rio de Janeiro: Qualitymark, 2002.

KROGH, G., ICHIJO, K., NONAKA, I. Facilitando a Criação do Conhecimento: Reinventando a Empresa com Poder de Inovação Contínua. Rio de Janeiro: Campus, 2001.

KRUGLIANSKAS, I., TERRA, J.C. Gestão do Conhecimento em Pequenas e Médias Empresas. Rio de Janeiro: Negócio, 2003.

LAKATOS, E. M., MARCONI, M. Metodologia Científica. São Paulo: Atlas, 2000, 3ed. 
LE BOTERF, Guy. De la Compétence: Essai sur un attracteur étrange. Paris: Les Éditions D'Organisation, 1995. 4ed.

LEONARD-BARTON, Dorothy. Wellsprings of Knowledge: Building and sustaining the sources of Innovation. Boston: Harvard Business School Press, 1995.

MACHLUP, Fritz. The Production and Distribution of Knowledge in the United States. Princeton: Princeton University Press, 1962.

MARTINS, Gilberto, LINTZ, A. Guia para Elaboração de Monografias e Trabalhos de Conclusão de Curso. São Paulo: Atlas, 2000.

MATTAR, Fauze N. Pesquisa de Marketing. São Paulo: Atlas, 1994.

MAXIMIANO, Antonio. Introdução à Administração. São Paulo: Atlas, 1986, 2ed.

MELO, S. C. O Marketing de Relacionamento como Fator de Influência na Lealdade do Cliente: Um estudo de caso no mercado de assinatura de revistas. Dissertação de Mestrado, FEA/USP, 2002.

MINTZBERG, Henry. Criando Organizações Eficazes. São Paulo: Atlas, 1995.

MIRANDA, Pontes. O Problema Fundamental do Conhecimento. Rio de Janeiro: Borsoi, 1972, 2ed.

MOINGEON, B., EDMONDSON, A. Organizational Learning and Competitive Advantage. Londres: Sage, 1996.

MOREIRA, Dirceu. A Potencialização do Capital Humano. São Paulo: Makron Books, 1999.

MYERS, Paul S (org). Knowledge Management and Organizational Design. USA: Butterworth-Heinemann, 1996.

NADLER, David. Pontos de Alavancagem Básicos para Melhor Desempenho Competitivo. In: NADLER, David. e outros. Arquitetura Organizacional. Rio de Janeiro: Campus, 1993.

NONAKA, Ikujiro. A empresa criadora de conhecimento. In: STARKEY, K. (org). Como as Organizações Aprendem. São Paulo: Futura, 1997.

NONAKA, I. TAKEUCHI, H. Criação de Conhecimento na Empresa. Rio de Janeiro: Campus, 1997.

OLIVEIRA, Djalma. Sistemas, Organizações e Métodos: Uma Abordagem Gerencial. São Paulo: Atlas, 2000, 11ed.

OLIVEIRA, Djalma. Estratégia empresarial: uma abordagem empreendedora. São Paulo: Atlas, 1991.

OLIVEIRA, Silvio Luiz. Tratado de Metodologia Científica. São Paulo: Pioneira, 2001.

OLIVEIRA Jr., Moacir Miranda. Administração do conhecimento em redes corporativas globais: Um estudo de caso na indústria da propaganda. Tese de Doutorado, FEA/USP,1999.

PEREIRA, M. I. A Transformação Organizacional na SABESP: O desenvolvimento do novo modelo de gestão. Dissertação de Mestrado, FEA/USP, 2000.

PERROTTI, Edoardo; ARMANDO, Eduardo; OLIVA, Fábio L. Gestão da Competitividade na Aliança Voith-Siemens. VI SEMEAD, FEA/USP,2003. 
PINTO, Ricardo Lopes. Evolução da Estrutura Organizacional ao Longo do Ciclo de Vida do Projeto: Um Estudo de Caso. Tese de Doutorado, FEA/USP,2002.

POLO, Edison F. Descentralização de Estrutura: Uma Contribuição às Destilarias de Álcool. Tese de Doutorado, FEA/USP,1987.

POLANYI, M. Personal Knowledge. Chicago: University of Chicago Press, 1958.

PRAHALAD, C.K. A Atividade dos Gerentes da nova era no emergente panorama competitivo. In: HESSELBEIN, F.; GOLDSMITH, M.; BECKHARD, R. A Organização do futuro. São Paulo: Futura, 1997.

PRUSAK, Laurence. Intoduction to Series - Why Knowledge, Why now? In: MYERS, Paul S (org). Knowledge Management and Organizational Design. USA: Butterworth-Heinemann, 1996.

QUINN, J.B.; ANDERSON, P.; FINKEKSTEIN, S. Gerenciando o Intelecto Profissional: Obtendo o máximo dos melhores. In: KLEIN, David. A Gestão Estratégica do Capital Intelectual: Recursos para a economia baseada no conhecimento. Rio de Janeiro: Qualitymark, 2002.

QUINN, J.B. Intelligent Enterprise. New York: Free Press, 1992.

REISMAN, Arnold. Management Science Knowledge: Its creation, generalization and consolidation. Londres: Quorum books, 1992.

ROBBINS, Stephen. Comportamento Organizacional. São Paulo: Prentice Hall, 2002.

ROMANI, C., DAZZI, M. C. S. Estilo Gerencial nas Organizações da Era do Conhecimento .In: ANGELONI, Maria Terezinha (coord.). Organizações do Conhecimento: infra-estrutura, pessoas e tecnologias. São Paulo: Saraiva, 2002.

ROSENBERG, Marc. e-Learning. São Paulo: Makron Books, 2001.

ROSSATTO, M.A, CAVALCANTI, M. Modelo Estratégico de Gestão do Conhecimento.XVI SNPTEE - Seminário Nacional de Produção e Transmissão de Energia Elétrica, Campinas/SP, Outubro 2001.

SAMMON, W.; KURLAND, M.; SPITALNIC, R. Business Competitor Intelligence: Methods for collecting, organizing and using information. New York: John Wiley\&Sons, 1984.

SCHEIN, Edgar H. Como Preparar o Terreno para a Mudança na Cultura Organizacional. In: SENGE, P. e outros. A Dança das Mudanças. Rio de Janeiro: Campus, 1999.

SCHEIN, Edgar H. Coming to a New Awareness of Organizational Culture. In: SCHEIN, Edgar H. The Art of Managing Human Resources. New York: Oxford University, 1987.

SCHEIN, Edgar H. Organizational Culture and Leadership. São Francisco: Jossey-Bass, 1985.

SCHRADER, Achim. Introdução à Pesquisa Social Empírica. Rio Grande do Sul: Globo, 1974.

SEVERINO, A.J. Metodologia do Trabalho Científico. São Paulo: Cortez, 2000. 
SENGE, P. e outros. A Dança das Mudanças. Rio de Janeiro: Campus, 1999.

SENGE, P. O novo trabalho do líder: Construindo organizações que aprendem. In: STARKEY, K. (org). Como as Organizações Aprendem. São Paulo: Futura, 1997.

SENGE, P. A Quinta Disciplina. São Paulo: Best Seller, 1990.

SHAW, Robert. A Capacidade de Agir: Criação de um Contexto para Delegação de Poder. In: NADLER, David. e outros. Arquitetura Organizacional. Rio de Janeiro: Campus, 1993.

SHAW, Robert; PERKINS, Dennis. Ensinar as Organizações a Aprender: O Poder dos Fracassos Produtivos. In: NADLER, David. e outros. Arquitetura Organizacional. Rio de Janeiro: Campus, 1993.

SIMERAY, J.P. A Estrutura da Empresa. Rio de Janeiro: Ao Livro Técnico, 1974.

SOUZA, M. C. Influência da Estrutura Organizacional e Perfil Gerencial sobre o Desempenho da Empresa. Dissertação de Mestrado, FEA/USP, 1982.

SROUR, Robert Henry. Poder, Cultura e Ética nas Organizações. São Paulo: Editora Campus, 1998, 4ed.

STARKEY, K. (org). Como as Organizações Aprendem. São Paulo: Futura, 1997.

STATA, Ray. Aprendizagem Organizacional: A chave da inovação gerencial. In: STARKEY, K. (org). Como as Organizações Aprendem. São Paulo: Futura, 1997.

STEWART, Thomas A. The Wealth of Knowledge. New York: Currency, 2001.

STEWART, Thomas A. Capital Intelectual. Rio de Janeiro: Campus, 1998.

SVEIBY, Karl Erik. The New Organizational Wealth: Managing and measuring knowledge-based assets. São Francisco: Berreth-Koehler Publishers, 1997.

TACHIZAWA, T. Metodologia de Pesquisa Aplicada à Administração. Rio de Janeiro: Pontal, 2002.

TAKAHASHI, Tadao (org.). Sociedade da Informação no Brasil: Livro Verde. Brasília: Ministério da Ciência e Tecnologia, 2000.

TEIXEIRA F ${ }^{\circ}$, Jayme. Gerenciando Conhecimento. Rio de Janeiro: SENAC, 2000.

TELES, A. X. Introdução ao Estudo da Filosofia. São Paulo: Ática, 1974.

TERRA, José Cláudio; ANGELONI, Terezinha. Understanding the Difference between Information Management and Knowledge Management. Terraforum website (www.terraforum.com.br), 2003c.

TERRA, José Cláudio. Twelve Lessons to Develop and Sustain Online Knowledge Communities. Terraforum website (www.terraforum.com.br), 2003b.

TERRA, José Cláudio. Gestão do Conhecimento e E-learning na prática. Rio de Janeiro: Elsevier, 2003a.

TERRA, José Cláudio. Gestão do Conhecimento: O Grande Desafio Empresarial. São Paulo: Negócio Editora, 2001, 2ed. 
TERRA, José Cláudio. Gestão do Conhecimento : Aspectos Conceituais e Estudo Exploratório sobre as Práticas de Empresas Brasileiras. Tese de Doutorado, POLI/USP,1999.

THUROW, Lester. A Construção da Riqueza. Rio de Janeiro: Rocco, 2001.

TURNER, Chris. O que são “Comunidades de Prática”?. In: SENGE, P. e outros. A Dança das Mudanças. Rio de Janeiro: Campus, 1999.

VASCONCELLOS, E. Notas de aula da disciplina EAD-5806 - Avaliação e Mudança na Estrutura Organizacional. São Paulo: FEA/USP, $1^{\circ}$. Trimestre 2003.

VASCONCELLOS, Eduardo. Estrutura das Organizações. São Paulo: Pioneira, 1989,2 ed.

VASCONCELLOS, E., KRUGLIANSKAS, I., SBRAGIA, R. Organograma Linear: Um Instrumento para Delineamento da Estrutura. São Paulo: FEA/USP, Revista de Administração v. 16, pg 8-20, Out-Dez-1981.

VASCONCELLOS, E. Estruturas Matriciais em Instituições de Pesquisa e Desenvolvimento do Estado de São Paulo. Tese de Livre Docência, FEA/USP,1978.

VASCONCELLOS, E. Contribuições ao Estudo da Estrutura Administrativa. Tese de Doutorado, FEA/USP,1972.

VIVEROS, M.A.H. Ontem e hoje em Administração. Natal: Clima, 1995.

WENGER, E.C., SNYDER, W. M. Communities of Practice: The organizacional frontier. Harvard Business Review, USA, pg 139-145, jan-fev/ 2000.

WIIG, Karl M. Knowledge Management. Arlington, USA: Schema Press, 1994.

YIN, Robert K. Case Study Research: Design and methods. Thousand Oaks, USA: Sage, 1994, 2ed.

ZUFFO, J.A. A Infoera. São Paulo: Saber, 1997.

\subsection{SITES PESQUISADOS (INTERNET)}

www.buckman.com

www.camargocorrea.com.br (consultado em 04.abr.2004)

www.eletropaulo.com.br (consultado em 08.mar.2004)

www.siemens.com (consultado em 04.abr.2004)

www.skandia.com

www.skyrme.com (consultado em 27.set.2003)

www.sveiby.com (consultado em 27.set.2003)

www.terraforum.com.br (consultado em 27.set.2003 e 08.04.2004) 
ANEXO 1

Roteiro de Entrevista 


\section{ANEXO 1: ROTEIRO DE ENTREVISTA}

\subsection{DADOS DO ENTREVISTADO}

Data: / /

Nome:

Área de Trabalho:
$\square$ Direção
$\square$ Recursos Humanos
Tecnologia da Informação
Pesquisa \& Desenvolvimento
Gestão do Conhecimento
$\square$ Marketing
$\square$ Planejamento Estratégico
$\square$ Outra

Experiência Profissional (em anos):
até 2
3-5
6-10
$11-20$
mais de 20

Cargo:

$\square$ Diretoria/Alta Administração $\quad \square$ Gerência/Nível Médio $\quad \square$ Outro

\subsection{DADOS DA EMPRESA}

Setor de atuação:

$\square$ Mecânico $\square$ Elétrico $\square$ Outro

Capital:

$\square$ Nacional $\quad \square$ Estrangeiro $\quad \square$ Estatal

Faturamento anual:

$\square$ Maior que US\$ 1 bilhão

Entre US\$ 500 milhões e US\$ 1 bilhão

Entre US\$ 250 milhões e US $\$ 500$ milhões

$\square$ Entre US\$ 100 milhões e US\$250 milhões

Entre US\$ 50 milhões e US\$ 100 milhões

Entre US\$ 20 milhões e US\$ 50 milhões

Menor que US\$ 20 milhões 


\subsection{CULTURA ORGANIZACIONAL}

1. Existe uma cultura de aprendizagem, criação ou compartilhamento do conhecimento na empresa? Como ela foi construída? Informação é poder?

\subsection{ESTRUTURA ORGANIZACIONAL}

\section{Nível de Formalização}

2. Existem critérios e políticas formais para facilitar e reger os processos de geração, validação e disseminação do conhecimento? Quais?

3. Os lay-outs proporcionam a troca informal de informações (uso de espaços abertos e salas de reunião)? Como?

\section{Critérios de Departamentalização}

4. Qual o critério de departamentalização adotado? Por que? (Solicitar o organograma).

5. Existe um departamento e/ou função específica para assuntos do conhecimento (Gerente/Diretor do Conhecimento)? Quais são as suas responsabilidades e atividades? Quais as competências necessárias? Qual o relacionamento com outros departamentos? Existem atividades conjuntas?

6. Há uso de equipes multidisciplinares e formais que se sobrepõem à estrutura formal tradicional hierárquica? Como elas são formadas e trabalham?

7. Há uso de equipes temporárias, autônomas, totalmente dedicadas a projetos de melhoria ou inovações? Como elas são formadas e trabalham?

\section{Atribuições: Atividades}

8. O líder tem alguma atribuição especial na estrutura organizacional para facilitar a geração e disseminação do conhecimento? Qual? 


\section{Atribuições: Níveis de decisão}

9. As decisões são tomadas no nível mais baixo possível? Privilegia-se o fluxo de poder de decisão ou de conhecimento nas tomadas de decisão? Por que?

10. Estimula-se a experimentação? Há liberdade para tentar e falhar?

\section{Atribuições: Comunicação}

11. A macro-estratégia e os resultados da empresa são comunicados para todos os níveis organizacionais?

12. Há comunicação em todos os sentidos (de cima para baixo, de baixo para cima e entre áreas distintas)? Existe linguagem e nomenclatura comum à todos?

13. Como as informações são compartilhadas? Existe amplo acesso, por parte dos funcionários, à base de dados da organização?

14. Há disciplina, eficiência e incentivo para documentação do conhecimento da empresa? Quais os métodos utilizados?

15. Como o assunto melhoria da comunicação entre os funcionários é gerenciado na empresa? Existe algum estímulo ao relacionamento face a face?

16. Quais os principais instrumentos de disseminação e compartilhamento de conhecimento tácitos e explícitos? Como a tecnologia é utilizada pela empresa como instrumento de disseminação do conhecimento e comunicação?

17. Existem comunidades de prática ou fóruns de debates? Como são criados e trabalham?

\subsection{APRENDIZAGEM}

18. Estimula-se o aprendizado através da ampliação dos contatos e interações com outras pessoas de dentro e fora da empresa? A empresa aprende muito com seus clientes e fornecedores? Quais mecanismos formais ou informais foram estabelecidos para esta finalidade?

19. Existem esquemas de premiação e reconhecimento por resultados e contribuições extraordinárias? Quais?

20. Existe estímulo ou programa de incentivo à rotação de pessoal? Como funciona?

21. Existe algum instrumento de registro e resgate das lições aprendidas?

22. Considerações finais do entrevistado. 